\title{
DOE/NV/11040-TI
}

\section{Summary of Hydrogeologic Controls on Ground-Water Flow at the Nevada Test Site, Nye County, Nevada}

\author{
By Randell J. Laczniak, James C. Cole, David A. Sawyer, and \\ Douglas A. Trudeau
}

\author{
U.S. GEOLOGICAL SURVEY \\ Water-Resources Investigations Report 96-4109
}

\author{
Prepared in cooperation with the \\ OFFICE OF ENVIRONMENTAL RESTORATION \\ AND WASTE MANAGEMENT \\ U.S. Department of Energy \\ Nevada Operations Office, under \\ Interagency Agreement DE-Al08-91NV11040
}

\section{DISCLAIMER}

This report was prepared as an account of work sponsored by an agency of the United States Government. Neither the United States Government nor any agency thereof, nor any of their employees, makes any warranty, express or implied, or assumes any legal liability or responsibility for the accuracy, completeness, or usefulness of any information, apparatus, product, or process disclosed, or represents that its use would not infringe privately owned rights. Reference herein to any specific commercial product, process, or service by trade name, trademark, manufacturer, or otherwise does not necessarily constitute or imply its endorsement, recommanufacturer, or othing by the United States Government or any agency thereof. The views and opinions of authors expressed herein do not necessarily state or reflect those of the United States Government or any agency thereof.
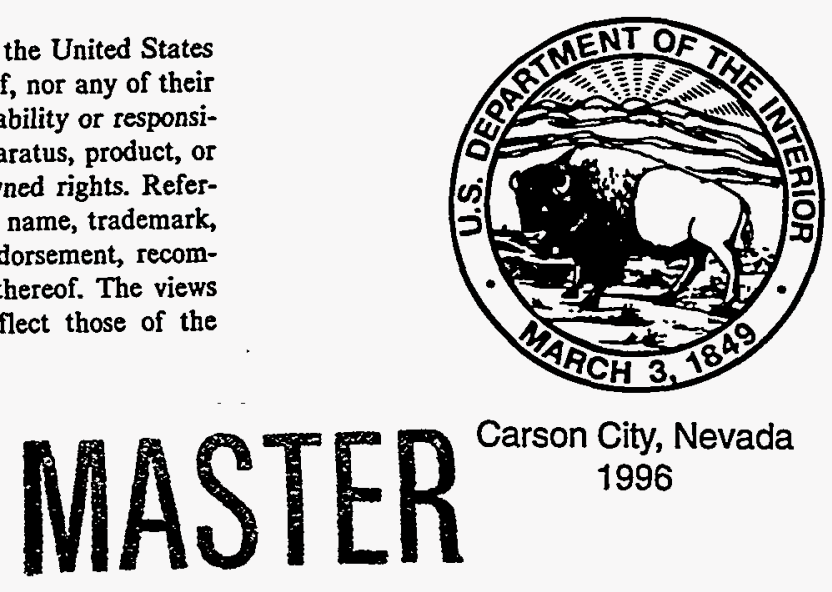


\title{
U.S. DEPARTMENT OF THE INTERIOR BRUCE BABBITT, Secretary
}

\author{
U.S. GEOLOGICAL SURVEY \\ -GORDON P. EATON, Director
}

Any use of trade names in this publication is for descriptive purposes

only and does not constitute endorsement by the U.S. Government

For additional information

write to:

District Chief

U.S. Geological Survey

333 West Nye Lane, Room 203

Carson City, NV 89706-0866
Copies of this report can be purchased from:

U.S. Geological Survey

Information Services

Box 25286, MS 517

Denver Federal Center

Denver, CO 80225-0046 


\section{DISCLAIMER}

Portions of this document may be illegible in electronic image products. Images are produced from the best available original document. 



\section{CONTENTS}

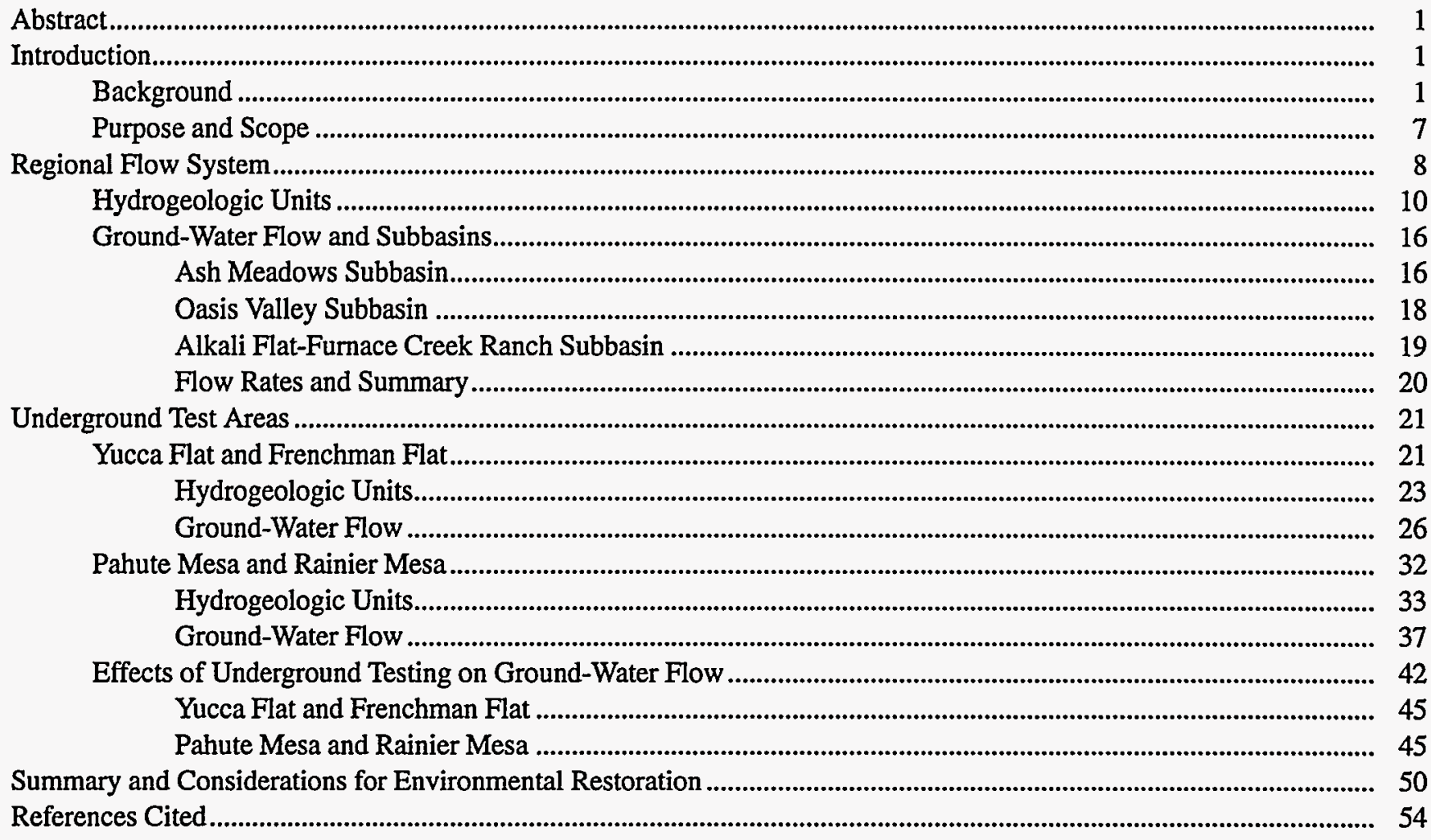

\section{PLATES}

[Plates in pocket at back of report]

1. Map showing major controls on regional ground-water flow at and near Nevada Test Site, southern Nevada and southeastern California

2. Sections showing major controls on ground-water flow at and near Nevada Test Site, southern Nevada and southeastern California

3. Map showing major controls on ground-water flow and distribution of hydrogeologic units at water table in Yucca Flat and Frenchman Flat areas, southern Nevada

4. Map and sections showing water levels, underground tests, and principal water-bearing units in upper 2,000 feet of saturated rock in Pahute Mesa area, southern Nevada

\section{FIGURES}

1-6. Maps showing:

1. Location of Nevada Test Site and local physiographic and geographic features

2. General areas of underground nuclear testing and other potential sources of subsurface contamination at Nevada Test Site

3. Location of Death Valley ground-water flow system in relation to local geographic features and areas of

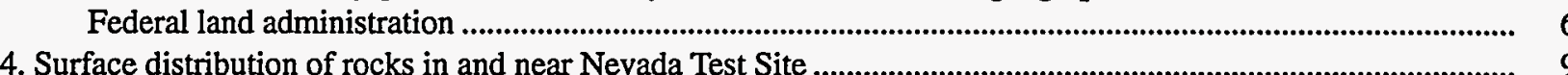

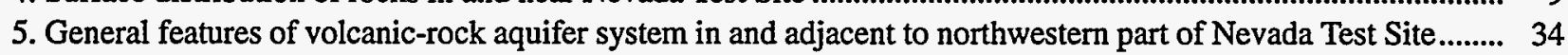

6. Major controls on ground-water flow in Pahute Mesa area ...................................................................................... 38

7. Diagrammatic section showing mechanical and hydrologic effects that may result from underground test detonated below water table 
8. Generalized longitudinal hydrogeologic section across central Yucca Flat showing mechanical effects of underground testing

9. Map showing general areas within Yucca Flat where sustained, local hydrologic effects may have resulted from underground testing

\section{TABLES}

1. Principal stratigraphic and associated hydrogeologic units of Nevada Test Site and vicinity

2. Nomenclature for hydrogeologic units of Nevada Test Site and vicinity.

3. General characteristics of ground-water subbasins of Nevada Test Site and vicinity

4. Distribution of underground tests relative to water table and estimated number of tests that have introduced test-generated contaminants into the ground-water flow system by major test area at the Nevada Test Site

5. Water levels, underground tests, and associated test and hole parameters used to determine general position of test relative to the water table.

\section{CONVERSION FACTORS AND VERTICAL DATUM}

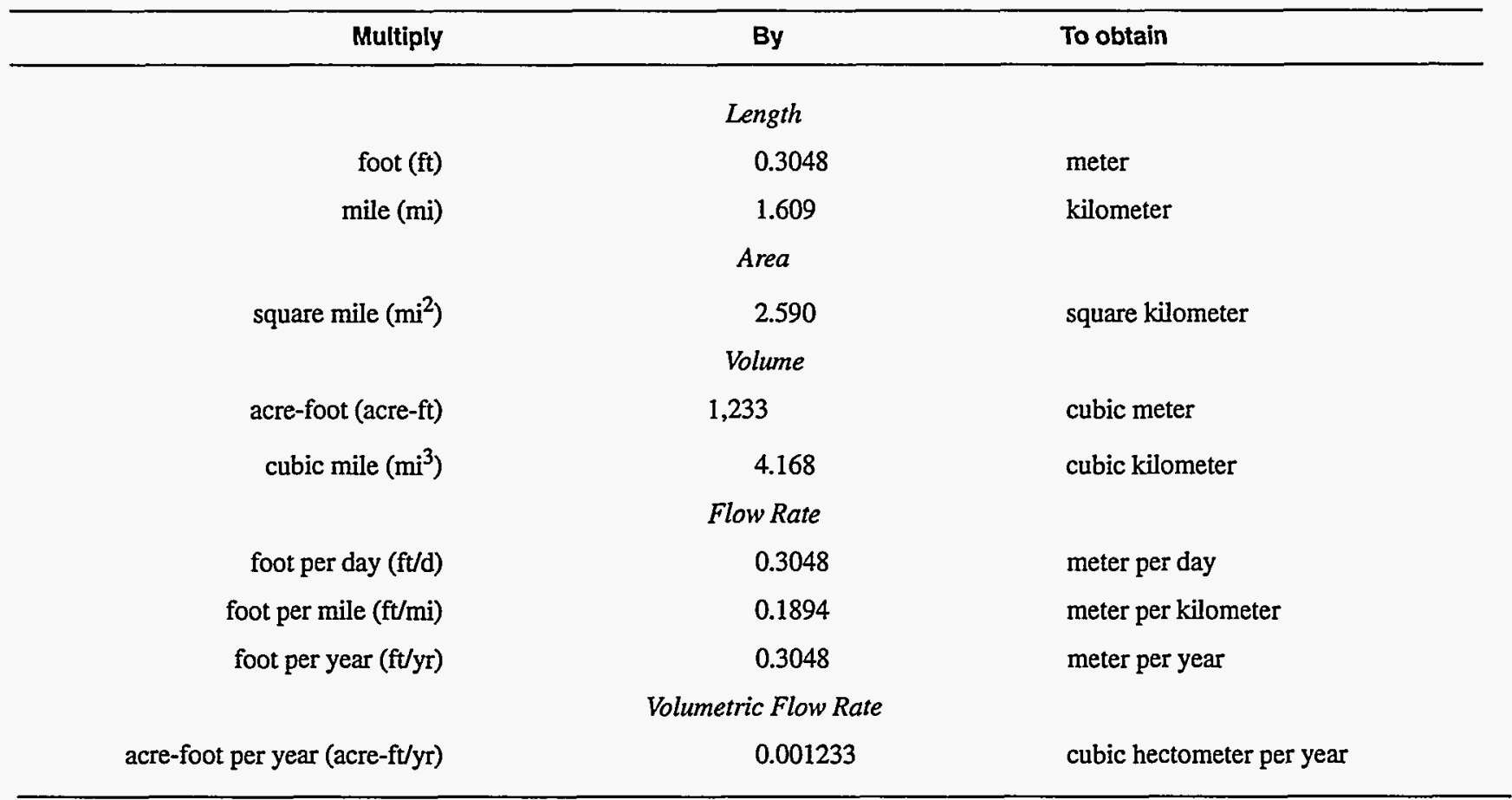

Sea level: In this report, "sea level" refers to the National Geodetic Vertical Datum of 1929 (NGVD of 1929, formerly called "Sea-Level Datum of 1929"), which is derived from a general adjustment of the first-order leveling networks of the United States and Canada. 


\title{
Summary of Hydrogeologic Controls on Ground-Water Flow at the Nevada Test Site, Nye County, Nevada
}

\author{
By Randell J. Laczniak, James C. Cole, David A. Sawyer, and Douglas A. Trudeau
}

\section{ABSTRACT}

The underground testing of nuclear devices has generated substantial volumes of radioactive and other chemical contaminants below ground at the Nevada Test Site (NTS). Many of the more radioactive contaminants are highly toxic and are known to persist in the environment for thousands of years. In response to concerns about potential health hazards, the U.S. Department of Energy, under its Environmental Restoration Program, has made NTS the subject of a long-term investigation. Efforts supported through the U.S. Department of Energy program will assess whether byproducts of underground testing pose a potential hazard to the health and safety of the public and, if necessary, will evaluate and implement steps to remediate any of the identified dangers.

Test-generated contaminants have been introduced over large areas and at variable depths above and below the water table throughout NTS. Evaluating the risks associated with these byproducts of underground testing presupposes a knowledge of the source, transport, and potential receptors of these contaminants. Ground-water flow is the primary mechanism by which contaminants can be transported significant distances away from the initial point of injection. Flow paths between contaminant sources and potential receptors are separated by remote areas that span tens of miles. The diversity and structural complexity of the rocks along these flow paths complicates the hydrology of the region. Although the hydrology has been studied in some detail, much still remains uncertain about flow rates and directions through the fractured-rock aquifers that transmit water great distances across this arid region. Unique to the hydrology of NTS are the effects of underground testing, which severely alter local rock characteristics and affect hydrologic conditions throughout the region.

Any assessment of the risk must rely in part on the current understanding of ground-water flow, and the assessment will be only as good as the understanding itself. This report summarizes what is known and inferred about ground-water flow throughout the NTS region. The report identifies and updates what is known about some of the major controls on ground-water flow, highlights some of the uncertainties in the current understanding, and prioritizes some of the technical needs as related to the Environmental Restoration Program.

An apparent deficiency in the current understanding is a lack of knowledge about flow directions and rates away from major areas of testing. Efforts are necessary to delineate areas of downgradient flow and to identify factors that constrain and control flow within these areas. These efforts also should identify the areas most critical to gaining detailed understanding and to establishing long-term monitoring sites necessary for effective remediation.

\section{INTRODUCTION}

\section{Background}

Since the early 1950's, the Nevada Test Site (NTS) has been the primary continental location for testing of nuclear weapons by the United States and for conducting experiments related to the peaceful 
application of nuclear explosions. The site, which occupies $1,350 \mathrm{mi}^{2}$ of south-central Nevada (fig. 1), was chosen by the Atomic Energy Commission (predecessor to the U.S. Department of Energy) primarily because of its remoteness from population centers and because of Federal control over much of the land (U.S. Department of Energy, 1993, p. 1). Initially, nuclear tests were detonated at or above land surface, but as the concerns over atmospheric fallout intensified during the late 1950's, more and more tests were detonated below ground in tunnels and shafts. Since July 1962 , and in accordance with the Limited Test Ban Treaty of 1963, all tests at NTS have been detonated beneath land surface (Office of Technology Assessment, 1989, p. 11-27; U.S. Department of Energy, 1994).

Activities at NTS over the past 40 years have generated a substantial amount of hazardous waste, both at the surface and underground (fig. 2). The largest volume of contaminants was produced as a direct consequence of nuclear testing (Bryant and FabrykaMartin, 1991). At NTS, 828 underground nuclear tests have been detonated (U.S. Department of Energy, 1994), most of which (more than 95 percent) were at Yucca Flat, Rainier Mesa, and Pahute Mesa (fig. 2). No tests have been detonated since October 1992. These nuclear devices were emplaced deep in the earth to contain their explosive force and radioactive byproducts within the subsurface, thus avoiding the release of radioactivity to the atmosphere. Even though water levels in the NTS region are generally more than $800 \mathrm{ft}$ below land surface, many of the intermediate and larger yield tests were detonated at depths near or below the water table to ensure the subsurface containment of radioactive byproducts (fig. 2). These tests have resulted in the introduction of radioactive and chemical contaminants into the regional ground-water flow system.

Individual test-generated contaminants differ considerably in terms of physical and chemical behavior and toxicity, and the after-shot distribution is difficult to define, in part because of dispersal by the test explosion itself (Borg and others, 1976). Contaminants produced by the detonation remain in the subsurface for many years. Where ground water contacts these contaminants, the potential for their migration is increased and their movement becomes dependent primarily on the rate and direction of ground-water flow. Thus, a knowledge of ground-water flow paths is essential to determine subsurface distributions and potential receptors of these test-generated byproducts.
The NTS is centrally located within the Death Valley ground-water flow system (fig. 3), one of the major hydrologic subdivisions of the southern Great Basin. It is estimated that more than 70,000 acre-ft of ground water are transmitted annually through this geologically diverse region (Blankennagel and Weir, 1973; Winograd and Thordarson, 1975; Harrill and others, 1988; Dettinger, 1989). In general, water moves southward through thick sequences of carbonate and volcanic rocks, away from areas of major recharge in central Nevada, toward areas of surface discharge at Ash Meadows, Oasis Valley, Alkali Flat, and Death Valley (fig. 1). Along these pathways, rain and snow on some of the intermediate mountain ranges and higher mesas contributes thousands of acre-feet of water into the underlying aquifers. Local communities and the numerous commercial and Federal facilities located throughout the area must rely on ground water for a large part of their water supply because surface water is limited in this arid region. Presently, wells throughout the flow system provide for agricultural, livestock, industrial, and domestic water needs, as do springs, which also support a diversity of wildlife and native vegetation.

A potential receptor of test-generated contaminants is the INTS workforce. More than 10 major water wells have been developed at NTS to provide water for drinking, industrial, and waste uses. Many of these wells, along with other drill holes on the NTS (fig. 2), have been sampled routinely for many years by the U.S. Department of Energy (USDOE) and the U.S. Environmental Protection Agency (USEPA). Samples have been tested for radioactive and other chemical constituents (Office of Technology Assessment, 1989; U.S. Environmental Protection Agency, 1991). No fission products have been detected in these samples, but tritium has been measured at concentrations greater than background (but not exceeding USEPA regulations for safe drinking water) in several of these wells. As a result of the USDOE practice of regularly monitoring drilling fluids at NTS, tritium and fission products have been detected in ground water at locations within the testing areas where none were expected (Borg and others, 1976; Hawkins and others, 1988, 1989; Nimz and Thompson, 1992). Although the concentrations of these contaminants generally have been low, tritium has been detected in excess of USEPA maximum permissible concentrations in a few samples at Yucca Flat (Crow, 1976) and at Pahute Mesa (Erikson, 1991; Nimz and Thompson, 1992). 


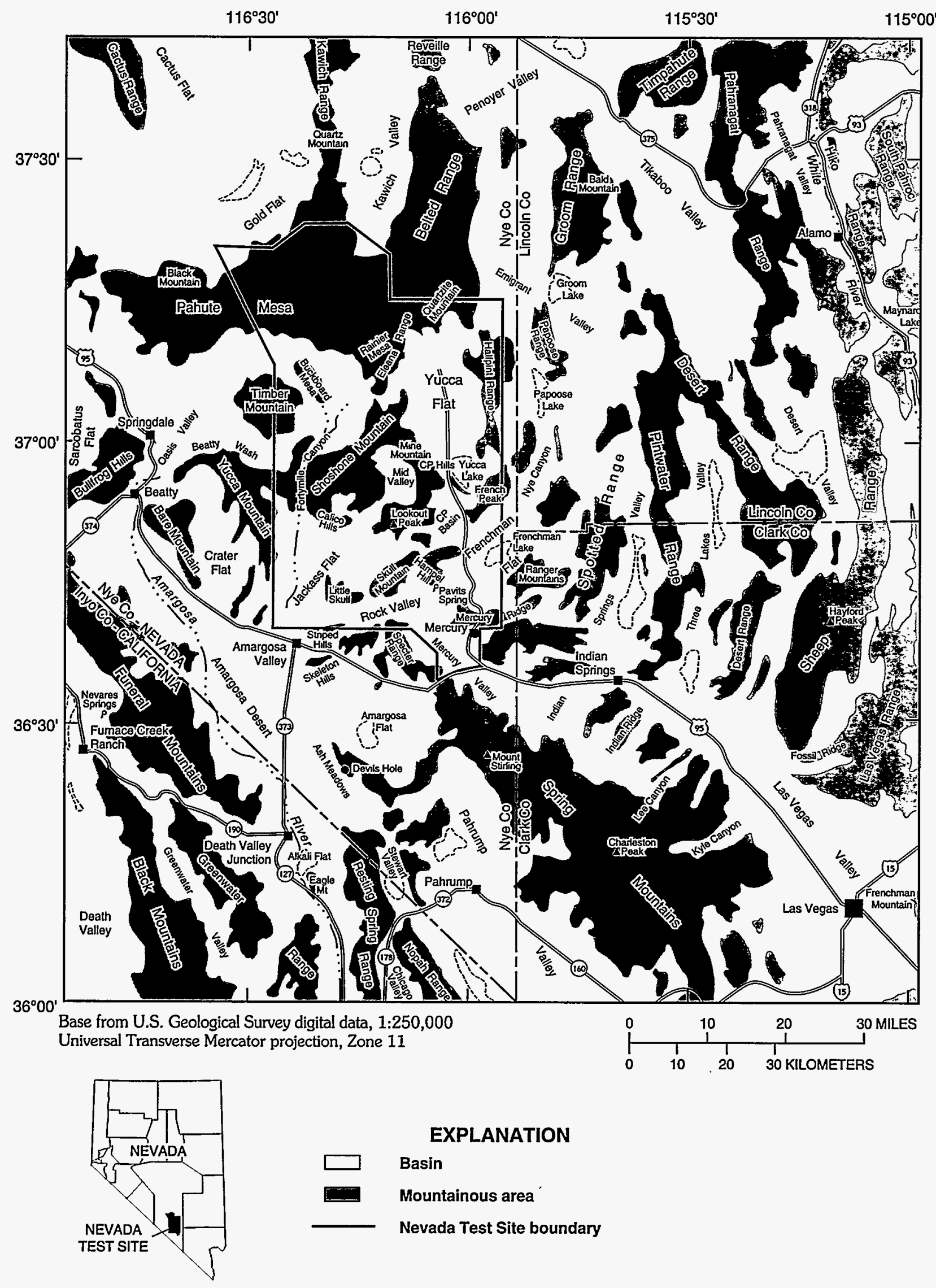

Figure 1. Location of Nevada Test Site and local physiographic and geographic features. 


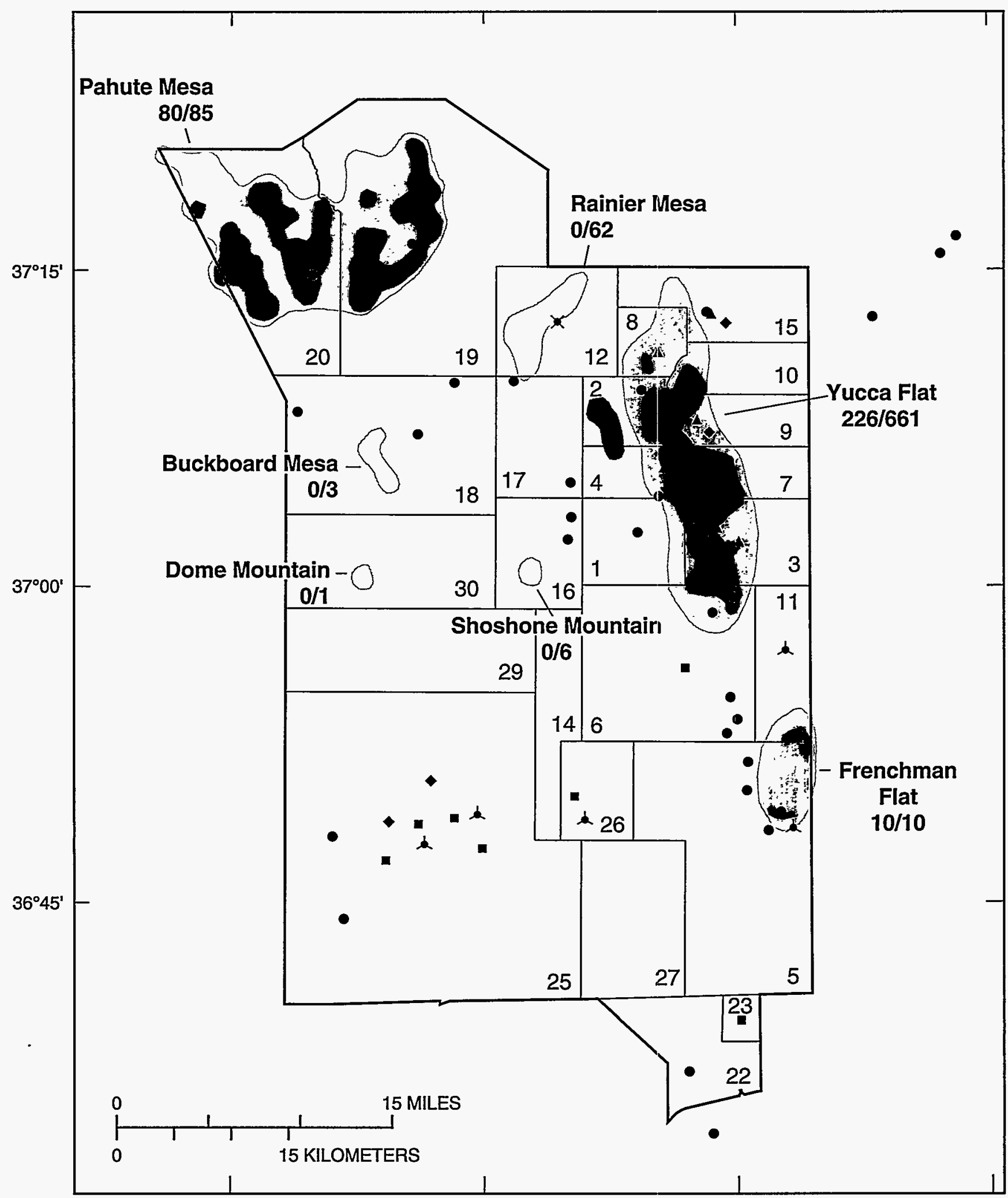

Base prepared by U.S. Geological Survey from digital data, 1:100,000 1979-89

Universal Transverse Mercator projection Zone 11

Figure 2. General areas of underground nuclear testing and other potential soulces of subsurface contamination at Nevada Test Site. 


\section{EXPLANATION}

Underground test area-Darker shading delineates area where tests were detonated near or below water table. Number of tests near or below water table and total number of tests are indicated preceding and following slash, respectively. From Bryant and Fabryka-Martin (1991) and U.S. Department of Energy (1991, 1994); see table 4 for additional information

\section{Nevada Test Site boundary}

3

Area boundary within Test Site-Area number is indicated

Other contaminant sources-From U.S. Department of Energy (1991)

* Tunnel tailings or drain pond

- Leachfield

4 Sump or injection well

$-\quad$ Storage tank

Waste site

- U.S. Environmental Protection Agency sampling well-From

U.S Environmental Protection Agency (1991)

Figure 2. Continued. 


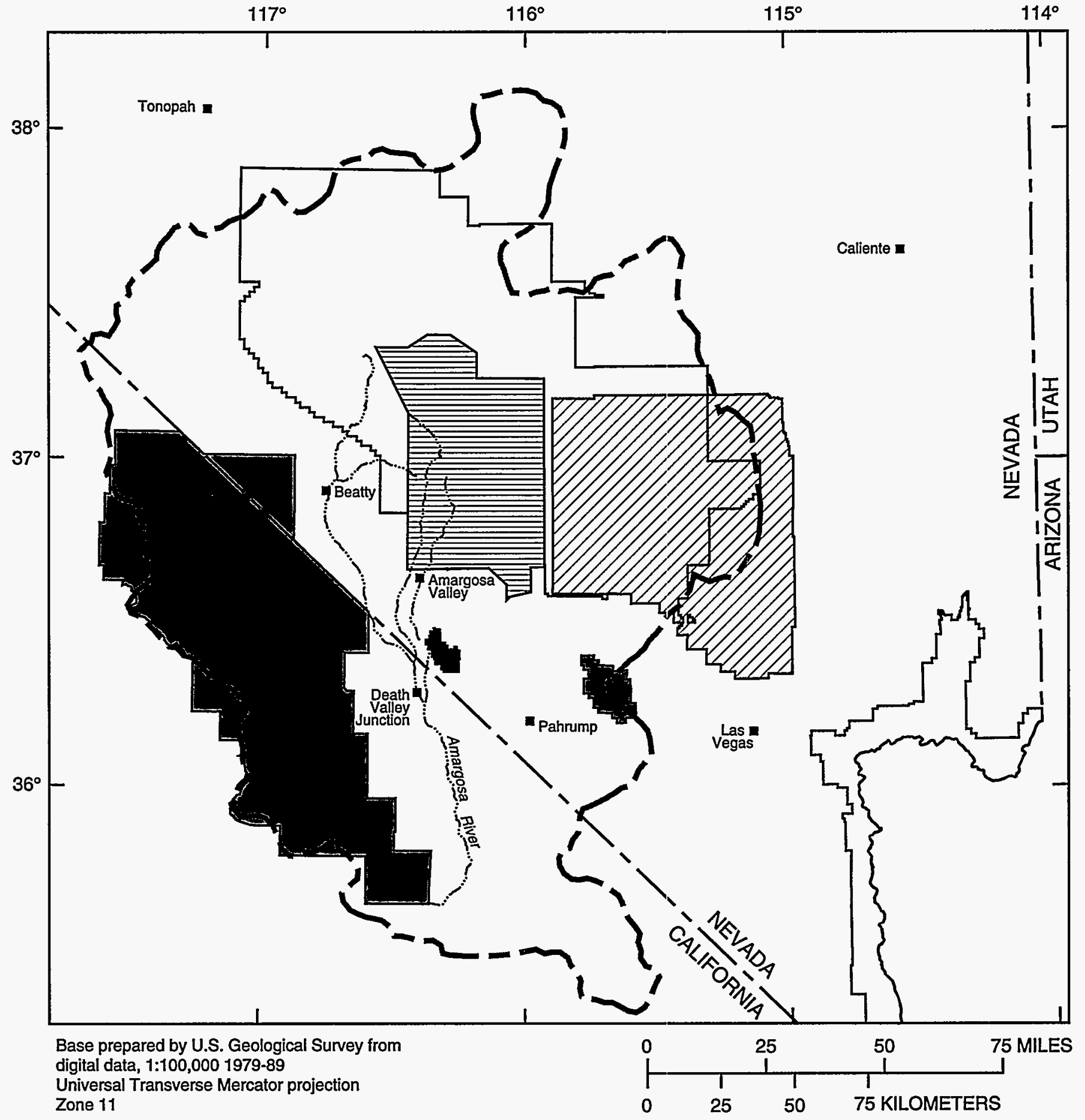

EXPLANATION

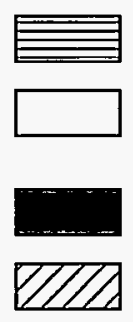

Nevada Test Site
Nellis Air Force Base Range-
Includes Tonopah Test Range
Death Valley National Park
Desert National Wildlife Range

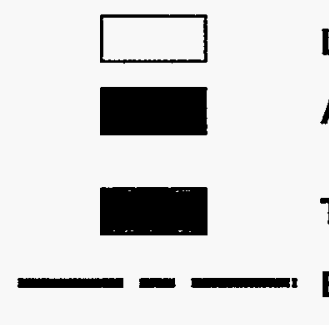

Lake Mead National Recreation Area

Ash Meadows National Wildlife RefugeIncludes Devils Hole

Toiyabe National Forest

Boundary of Death Valley ground-water flow system-Modified from Harrill and others $(1988$, sheet 1$)$

Figure 3. Location of Death Valley ground-water flow system in relation to local geographic features and areas of Federal land administration.

6 Summary of Hydrogeologic Controls on Ground-Water Flow at the Nevada Test Site, Nye County, Nevada 
Water users west and south of NTS also are considered potential receptors because they are downgradient of the contaminant sources. Ground water has been developed for drinking, livestock, agriculture, mining, and waste use at numerous wells in Oasis Valley, throughout the Amargosa Desert, and at the communities of Beatty, Springdale, and Amargosa Valley, Nev., and Death Valley Junction and in the Death Valley National Park, Calif. (figs. 1 and 3). Springs and seeps in upper Oasis Valley near Beatty, in the Ash Meadows National Wildlife Refuge, and at Alkali Flat have sustained wetlands, which support a variety of wildlife and some recreational activities. Further development of ground water from NTS and adjacent areas is expected in response to continued Federal activities at NTS and Nellis Air Force Range. In addition, projected growth of the Las Vegas urban area and some of the smaller communities throughout the region may lead to the further development of water resources in the NTS area.

Radioactive and other potential chemical contaminants at NTS are the subject of a long-term program of investigation and remediation by USDOE under its Environmental Restoration Program (U.S. Department of Energy, 1991, p. 2). Within the framework of applicable Federal and State regulations, the program will endeavor to assess the extent of contamination and to evaluate the potential risks to man and the environment from byproducts of testing. A more complete understanding of ground-water flow at NTS is essential to evaluate future environmental risk and to assess strategies for removing, containing, treating, and monitoring any contaminants.

The identification and characterization of contaminated ground water will be especially challenging at NTS because (1) contaminants have been introduced in both saturated and unsaturated rock at variable depths ( 50 to $4,800 \mathrm{ft}$ below land surface); (2) the physical and chemical conditions near the point of detonation (contaminant source) are poorly known; (3) the subsurface environment is hydrogeologically complex; and (4) the contaminated areas are large and geologically diverse. Further, the interactions between radioactive and chemical byproducts of testing and the ground-water flow system are not adequately understood. A thorough understanding of specific flow paths is imperative to determine and implement a successful remediation program because of the high chemical toxicity and radioactivity of many of the radionuclides. Present data are inadequate to define specific pathways between contaminant sources and potential receptors. Most quantitative estimates given for rates of groundwater flow (Blankennagel and Weir, 1973, table 9; Winograd and Thordarson, 1975, tables 14 and 15; Winograd and Pearson, 1976; Claassen, 1985, p. 29; Brikowski, 1992, p. 18) do not necessarily represent flow rates along any specific flow path, but rather are averages for large areas. Estimates of minimum flow times and maximum exposure risks will not be possible until local flow systems are more fully explored and their hydrologic properties better quantified, and until hydrologic and geologic information is obtained from areas beyond those that have been partially explored as an outgrowth of the testing program.

\section{Purpose and Scope}

This report summarizes the current scientific understanding about ground-water flow beneath the NTS region, and highlights uncertainties in our knowledge of hydrogeologic conditions in what is considered one of the more complex flow systems on the continent. The report is not intended to endorse or dispute any specific remedial activity, but rather to provide basic hydrologic and geologic information and a fundamental understanding of subsurface conditions, from which programs and policies can be developed and implemented to promote effective and efficient cleanup and ensure the long-term protection of ground-water resources.

This report is based largely on published reports of earlier hydrologic investigations by the U.S. Geological Survey during the 1960's and 1970's; on published and unpublished reports documenting complimentary work done by other organizations; and on published U.S. Department of Energy reports through 1992 documenting planning and strategies for environmental restoration at NTS. Additional information from more recent geologic mapping and new structural interpretations in the region by the U.S. Geological Survey, the University of Nevada-Reno, and others also is incorporated and referenced. Water-level data presented throughout this report represent measured values through 1991, but these levels are not everywhere comparable from hole to hole because of differences in hole construction and numerous other factors. The hydrologic concepts and interpretations summarized herein do not differ significantly from those presented by Blankennagel and Weir (1973) and Winograd 
and Thordarson (1975). In part, this similarity is because only a few additional hydrologic test holes have been completed within the NTS region since their investigations.

Because of the extent, geologic diversity, and hydrologic complexity of the ground-water flow system in the NTS region, this report first describes the occurrence and movement of ground water at the regional scale. This is followed by a description of the geology and hydrology of the primary areas of underground testing. The report also describes testinduced effects on hydrogeologic conditions and some potential effects of testing on contaminant migration.

Although the report focuses mainly on the hydrogeologic features pertinent to the migration of contaminants away from areas of underground testing, additional non-test-related sources of contamination are present throughout NTS. These sources include low-level radioactive waste facilities, inactive storage tanks and waste-water sumps, and a few shallow liquid-waste injection wells (fig. 2; U.S. Department of Energy, 1991). Tailings mined from tunnels into Rainier Mesa also contain radioactive materials, as does the mine drainage that flows into nearby surface evaporation ponds and infiltrates through surficial soil zones. Large surface areas at NTS and at Nellis Air Force Base Range to the east contain plutoniumcontaminated soils that resulted from early transportation and safety tests in which nuclear warheads were destroyed by conventional explosives (U.S. Department of Energy, 1991, p. 142-146; 1994). Non-test and test-generated radioactive materials noted above may contribute contaminants to the regional aquifers, but the rate of influx probably is slowed by the thick unsaturated zone and the limited recharge from precipitation. Although these sources also must be investigated, they are not discussed in detail here because none is considered to contribute significant contamination to the regional ground-water flow system.

\section{REGIONAL FLOW SYSTEM}

The NTS is within the southern Great Basin region, an internally drained part of the Basin and Range physiographic province. The region is characterized by low rainfall, intermittent streams, internal surface drainages, and large, sparsely distributed springs. Several major flow systems convey ground water through this region (Rush, 1970; Harrill and others, 1988). Ground water moves under the influence of hydraulic gradients along convoluted pathways between areas of recharge (characterized as areas of higher precipitation) and areas of surface discharge (characterized by springs and wet playas). The movement of ground water along these flow paths is controlled largely' by the water-transmitting characteristics of the host rock. These characteristics depend on the primary and secondary properties of the rock (principally porosity and permeability). Primary properties are those created during deposition of the rocks; and secondary properties are those created after deposition, usually as a result of faulting, fracturing, dissolution, or the precipitation of mineral cements. Secondary properties associated with major geologic structures throughout the region may exhibit significant control on the regional flow of ground water in some areas.

The NTS lies totally within the Death Valley ground-water flow system. The Death Valley flow system covers an area of about $15,800 \mathrm{mi}^{2}$ of the southern Great Basin between its principal recharge areas in the high mountains of central Nevada and its southernmost areas of discharge in Death Valley, Calif. (Harrill and others, 1988). The flow system consists primarily of volcanic rock in the west and carbonate rock in the east (fig. 4) and is estimated to transmit more than 70,000 acre-ft of ground water annually (Blankennagel and Weir, 1973, p. 19-20; Winograd and Thordarson, 1975; Harrill and others, 1988, sheet 2; Dettinger, 1989 , p. 17-25). The largest part is conveyed through a thick sequence of Paleozoic carbonate rock, referred to as the "central carbonate corridor," that extends throughout the subsurface of much of central and southeastern Nevada (Dettinger, 1989, p. 13).

Hydrogeologic information throughout most of the area is scant because of the sparse population and the difficulty and high cost associated with drilling wells to the extreme depths required to reach the regional water table. In contrast, some areas such as NTS and a few small agricultural regions in the lower Amargosa Desert have high concentrations of wells. These wells have provided useful information to many regional investigations, but many of the data were of limited value because wells were not constructed for the acquisition of hydrologic information. Thus, present interpretations of regional ground-water flow are limited by sparse and inconsistent hydrologic data, regarding water levels, water chemistry, and the waterbearing characteristics of rocks. 


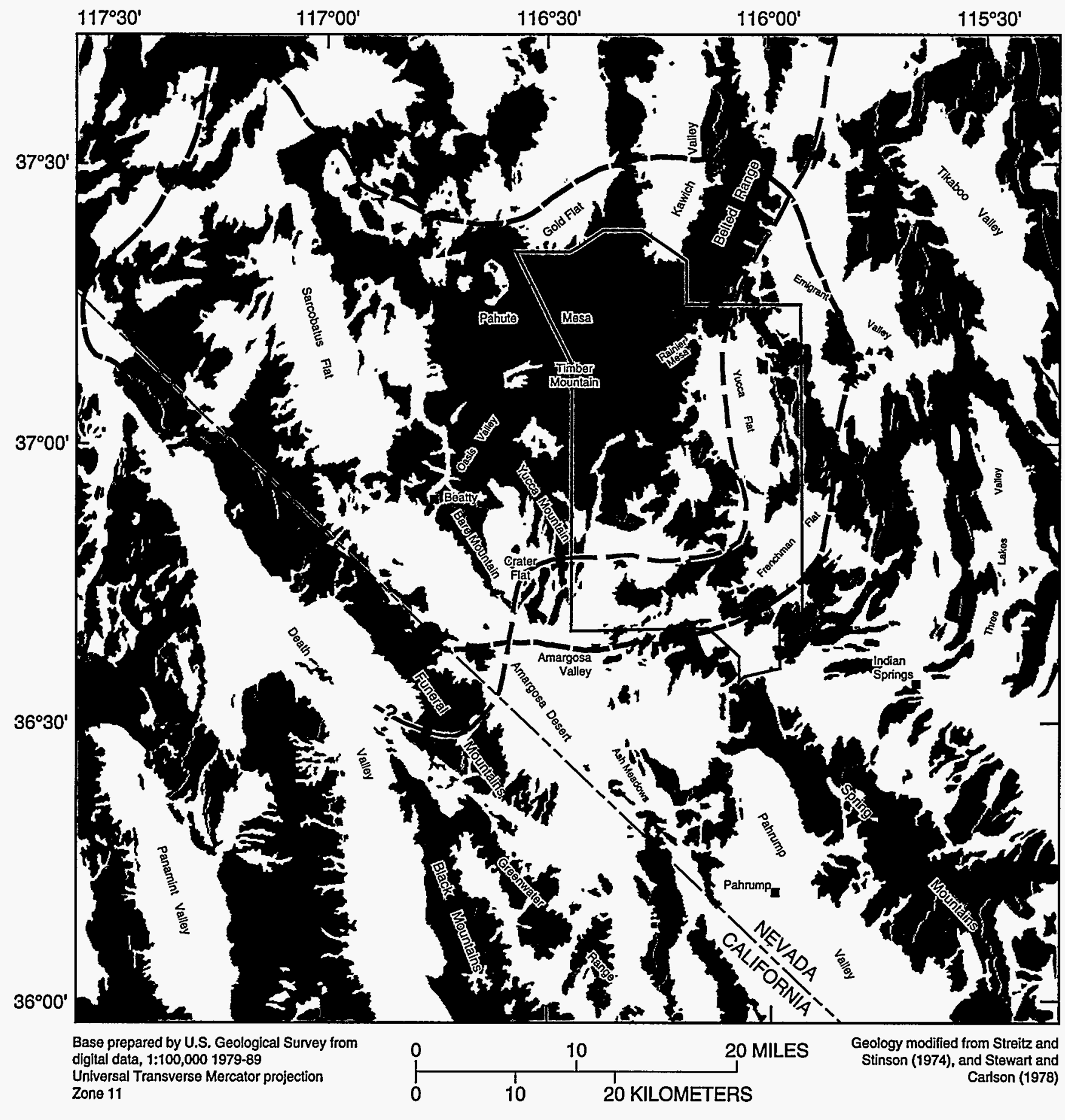

EXPLANATION

\begin{tabular}{llllll}
$\square$ & Valley fill & & Carbonate rock & Granitic rock \\
\hline & Volcanic rock & & Clastic rock
\end{tabular}
- Boundary of southwest Nevada volcanic field-Modified from Carr and others (1986, fig. 1)
- Subsurface boundary of regional carbonate-rock aquifer-Approximate western limit of area where carbonate-rock aquifer is known to dominate ground-water flow system Nevada Test Site boundary

Figure 4. Surface distribution of rocks in and near Nevada Test Site. 


\section{Hydrogeologic Units}

Ground water flowing beneath NTS passes through a diverse assemblage of rocks (pls. 1 and 2) that differ substantially in terms of stratigraphic age, lithologic composition, and water-bearing properties. These rocks form a complex three-dimensional framework of ground-water conduits and barriers that can be described as hydrogeologic units (aquifers and confining units) on the basis of their ability to store and transmit water (table 1). This framework differs significantly from a simple layer-cake model in that (1) the initial geometric shape of the rock units ranges from tabular to lenticular to cylindrical; (2) structural and erosional modifications have changed the thickness and lateral continuity of most major rock units; (3) hydrothermal alteration, contact metamorphism, diagenesis, and thermal-mechanical effects of underground testing have modified rock-hydraulic properties to differing degrees locally; and (4) tectonic fracturing has altered permeability along fault zones.

Knowledge of this three-dimensional framework has significant gaps, but regional studies provide the basis for predicting the locations of major regional hydrogeologic units that convey most of the ground water within the upper 5,000 to $7,000 \mathrm{ft}$ of the Earth's crust. These major water-bearing units, first enumerated by Winograd and Thordarson (1975), are revised somewhat here and designated (1) the basement confining unit, (2) the carbonate-rock aquifer, (3) the Eleana confining unit, (4) the volcanic aquifers and confining units, and (5) the valley-fill aquifer (table 2). Although each of these regional units has internal complexities and although different parts of the NTS region are strongly influenced by different combinations of units, these major subdivisions are useful descriptive elements of the overall conceptual framework.

The rocks that make up these major regional hydrogeologic units include parts of a thick sequence (more than 35,000 ft) of Paleozoic and older sedimentary rocks (about 600 to more than 280 million years before present [Ma]), local intrusive bodies of Cretaceous granite (about $100 \mathrm{Ma}$ ), a thick and variable assemblage of Miocene volcanic rocks (about 16 to $8 \mathrm{Ma}$ ), and locally thick deposits of post-volcanic gravel and sand that fill the valleys (Frizzell and Shulters, 1990).

Major structural events also have left their imprint on the rocks of the area. This region of the western United States was a stable continental margin until late Devonian time, about 370 Ma, when uplift west and north of NTS resulted in erosion of an offshore volcanic arc and deposition of thick Mississippian sandstones and shales in an active foreland basin (Poole, 1974; Poole and Sandberg, 1991; Cole and others, 1994). Compressional deformation during the Sevier orogeny (about 150 to $100 \mathrm{Ma}$ ) produced regional thrusts, folds, and (probable) wrench faults that fundamentally rearranged the positions of Paleozoic and older sedimentary rocks, both in terms of depth and geographic distribution (Armstrong, 1968; Barnes and Poole, 1968). Several lines of evidence suggest that the Sevier orogenic zone, including NTS, may have subsequently been extended by normal faults prior to the intrusion of minor granites at about $100 \mathrm{Ma}$ (Hodges and Walker, 1992; Cole and others, 1993).

Following erosion throughout most of the early Tertiary period ( 65 to $30 ? \mathrm{Ma}$ ), the area in and around NTS began to be pulled apart along low-angle normal faults and strike-slip faults associated with the formative stages of the modern Basin and Range structural province (Guth, 1981, 1990; Hamilton, 1988; Wernicke and others, 1988; Cole and others, 1990). Eruptions of the southwest Nevada volcanic field (fig. 4) began at about $16 \mathrm{Ma}$ and continued without major interruption until about $8 \mathrm{Ma}$ (Byers and others, 1976; Sawyer and others, 1990; Sawyer and others, 1994). Successive eruptions produced no less than seven large and partially overlapping calderas, which were filled with lava flows and blanketed by vast deposits of tuff. In the central subsided block of the Silent Canyon caldera complex beneath Pahute Mesa, for example, volcanic rock accumulated to a depth of more than 13,000 ft (Byers and others, 1976). Extension continued during and after volcanic activity and caused further tilting and lateral translation of major upper crustal blocks in some places. Modern alluvial basins (about $10 \mathrm{Ma}$ to present) have progressively filled with as much as $4,000 \mathrm{ft}$ of coarse gravel and sand, and locally fine grained playa-lake deposits of silt and clay.

The lowermost $10,000 \mathrm{ft}$ of the pre-Tertiary section consists of Eocambrian to Middle Cambrian quartzite, micaceous quartzite, and siltstone. Together these units make up subregional quartzite confining unit (table 2) that functions as the lower confining zone (hydrologic basement) throughout much of the Death Valley flow system because of its generally low watertransmitting characteristics. Where exposed by uplift in the northern Halfpint, Groom, Papoose, and Desert 
Table 1. Principal stratigraphic and associated hydrogeologic units of Nevada Test Site and vicinity

[Based on information from Blankennagel and Weir, 1973, table 1; Winograd and Thordarson, 1975, table 1; Byers and others, 1976; Cole and others, 1990; Sawyer and others, 1990; Sawyer and others, 1994; and R.G. Warren, Los Alamos National Laboratory, written commun., 1991]

\begin{tabular}{|c|c|c|c|c|}
\hline \multicolumn{2}{|c|}{ Stratigraphic unit ${ }^{1}$} & Principal lithology 2 & Hydrogeologic unit 3 & $\begin{array}{l}\text { Known or inferred } \\
\text { hydrologic significance }\end{array}$ \\
\hline \multicolumn{2}{|l|}{$\begin{array}{l}\text { Valley-fill deposits } \\
\text { [Qa, QTa, Qp, Qe, Qc] } \\
\text { Miocene to Quaternary }\end{array}$} & $\begin{array}{l}\text { Gravel and sand (eolian sand } \\
\text { and lakebed deposits) }\end{array}$ & Valley-fill aquifer & $\begin{array}{l}\text { Generally unsaturated except in deepest } \\
\text { structural basins at Yucca Flat, Frenchman } \\
\text { Flat, Emigrant Valley, and Amargosa } \\
\text { Desert. Saturated thickness highly vari- } \\
\text { able and can exceed } 1,000 \mathrm{ft} \text { locally; local } \\
\text { source of recharge to regional carbonate- } \\
\text { rock aquifer. Fine-grained lakebed depos- } \\
\text { its present in Ash Meadows area may } \\
\text { inhibit regional flow and divert ground } \\
\text { water to surface [AM, OV, AFFCR] }\end{array}$ \\
\hline \multicolumn{2}{|l|}{$\begin{array}{l}\text { Basalt } \\
\text { [Qb, QTb, Tb] } \\
\text { Miocene to Quaternary }\end{array}$} & $\begin{array}{l}\text { Basalt in thin flows, dikes, } \\
\text { and cinder cones }\end{array}$ & $n / c$ & $\begin{array}{l}\text { Generally unsaturated; dikes and local flows } \\
\text { may influence local ground-water move- } \\
\text { ment [OV, AFFCR, AM] }\end{array}$ \\
\hline \multirow{4}{*}{$\begin{array}{l}\text { Timber Mountain Group } \\
\text { [Tm] } \\
12.5-11.5 \mathrm{Ma}\end{array}$} & Ammonia Tanks Tuff & $\begin{array}{l}\text { Variable welded ash-flow tuff } \\
\text { (bedded tuff) }\end{array}$ & Welded-tuff aquifer & $\begin{array}{l}\text { Generally unsaturated except in Oasis Val- } \\
\text { ley and possibly Jackass Flats [OV, } \\
\text { AFFCR?] }\end{array}$ \\
\hline & $\begin{array}{l}\text { Rhyolite of } \\
\text { Tannenbaum Hill }\end{array}$ & Rhyolite lava & Lava-flow aquifer & $\begin{array}{l}\text { Local aquifer in northwestern part of Timber } \\
\text { Mountain caldera [AFFCR, OV] }\end{array}$ \\
\hline & Rainier Mesa Tuff & $\begin{array}{l}\text { Variably welded ash-flow tuff } \\
\text { (nonwelded tuff; rhyolite } \\
\text { lava) }\end{array}$ & Welded-tuff aquifer & $\begin{array}{l}\text { Major aquifer in deeper parts of Yucca Flat, } \\
\text { CP Basin, Frenchman Flat, and Jackass } \\
\text { Flats, and in western Pahute Mesa and } \\
\text { Oasis Valley [AM, AFFCR, OV] }\end{array}$ \\
\hline & $\begin{array}{l}\text { Pre-Rainier Mesa } \\
\text { rhyolites }\end{array}$ & $\begin{array}{l}\text { Rhyolite lava (nonwelded } \\
\text { tuff) }\end{array}$ & Lava-flow aquifer & $\begin{array}{l}\text { Local aquifers in Pahute Mesa and at Yucca } \\
\text { Mountain [AFFCR] }\end{array}$ \\
\hline \multirow{2}{*}{$\begin{array}{l}\text { Paintbrush Group } \\
\text { [Tp] } \\
12.8-12.7 \mathrm{Ma}\end{array}$} & \begin{tabular}{|l|} 
Middle Paintbrush \\
Group rhyolites \\
(includes rhyolites \\
of Echo Peak and \\
Silent Canyon)
\end{tabular} & $\begin{array}{l}\text { Rhyolite lava (welded ash- } \\
\text { flow tuff; nonwelded tuff, } \\
\text { locally zeolitized) }\end{array}$ & $\begin{array}{l}\text { Lava-flow aquifer } \\
\text { (welded-tuff } \\
\text { aquifer; tuff } \\
\text { confining unit) }\end{array}$ & $\begin{array}{l}\text { Local aquifers in Pahute Mesa; minor con- } \\
\text { fining unit at Yucca Mountain [AFFCR] }\end{array}$ \\
\hline & Topopah Spring Tuff & $\begin{array}{l}\text { Variably welded ash-flow tuff } \\
\text { (nonwelded tuff, locally } \\
\text { zeolitized) }\end{array}$ & $\begin{array}{l}\text { Welded-tuff aquifer } \\
\text { (tuff confining unit) }\end{array}$ & $\begin{array}{l}\text { Major aquifer in western Pahute Mesa, Jack- } \\
\text { ass Flats, southern Yucca Flat, CP Basin, } \\
\text { and Frenchman Flat [OV, AFFCR, AM] }\end{array}$ \\
\hline \multirow[t]{2}{*}{$\begin{array}{l}\text { Calico Hills Formation } \\
\text { [Ta] } \\
12.9 \mathrm{Ma}\end{array}$} & Volcanics of Area 20 & $\begin{array}{l}\text { Rhyolite lava and nonwelded } \\
\text { tuff, commonly zeolitized } \\
\text { (welded tuff) }\end{array}$ & $\begin{array}{l}\text { Lava-flow aquifer, } \\
\text { tuff confining unit } \\
\text { (welded-tuff } \\
\text { aquifer) }\end{array}$ & $\begin{array}{l}\text { Major aquifer in central and western Pahute } \\
\text { Mesa; major confining unit in eastern } \\
\text { Pahute Mesa, Yucca Mountain, Jackass } \\
\text { Flats, and Yucca Flat [AFFCR, OV?] }\end{array}$ \\
\hline & Rhyolite of Inlet & Rhyolite lava & Lava-flow aquifer & $\begin{array}{l}\text { Major aquifer in eastern and central Pahute } \\
\text { Mesa [AFFCR, OV?] }\end{array}$ \\
\hline
\end{tabular}


Table 1. Principal stratigraphic and associated hydrogeologic units of Nevada Test Site and vicinity-Continued

\begin{tabular}{|c|c|c|c|c|}
\hline \multicolumn{2}{|c|}{ Stratigraphic unit ${ }^{1}$} & Principal lithology 2 & Hydrogeologic unit ${ }^{3}$ & $\begin{array}{c}\text { Known or Inferred } \\
\text { hydrologic significance }\end{array}$ \\
\hline \multicolumn{2}{|l|}{$\begin{array}{l}\text { Wahmonie Formation } \\
{[\mathrm{Tw}]} \\
13.0 \mathrm{Ma}\end{array}$} & $\begin{array}{l}\text { Andesite and dacite volcanic } \\
\text { breccia (lava; nonwelded } \\
\text { tuff) }\end{array}$ & $\begin{array}{l}\text { Tuff confining unit } \\
\text { (lava-flow aquifer } \\
\text { or confining unit?) }\end{array}$ & $\begin{array}{l}\text { Confining unit west of Frenchman Flat and } \\
\text { in Jackass Flats; contains perched water } \\
\text { near Cane Springs and Pavits Spring; thin } \\
\text { confining unit in Yucca Flat [AM, } \\
\text { AFFCR] }\end{array}$ \\
\hline \multirow{2}{*}{$\begin{array}{l}\text { Crater Flat Group } \\
\text { [Tc] } \\
13.25-13.1 \mathrm{Ma}\end{array}$} & Middle units & $\begin{array}{l}\text { Rhyolite lava (latite lava; } \\
\text { nonwelded tuff) }\end{array}$ & Lava-flow aquifer & $\begin{array}{l}\text { Local aquifers in Pahute Mesa; confining } \\
\text { units where nonwelded and zeolitized } \\
\text { [AFFCR,AM] }\end{array}$ \\
\hline & Bullfrog Tuff & $\begin{array}{l}\text { Variably welded ash-flow tuff } \\
\text { (nonwelded tuff, } \\
\text { commonly zeolitized) }\end{array}$ & $\begin{array}{l}\text { Welded-tuff aquifer } \\
\text { (tuff confining unit) }\end{array}$ & $\begin{array}{l}\text { Major aquifer at Yucca Mountain; major } \\
\text { confining unit in Pahute Mesa [AFFCR, } \\
\text { AM] }\end{array}$ \\
\hline \multirow{2}{*}{$\begin{array}{l}\text { Belted Range Group } \\
\text { [Tb] } \\
13.85-13.6 \mathrm{Ma}\end{array}$} & $\begin{array}{c}\text { Deadhorse Flat } \\
\text { Formation }\end{array}$ & $\begin{array}{l}\text { Rhyolite lava and variably } \\
\text { welded ash-flow tuff } \\
\text { (nonwelded tuff, } \\
\text { commonly zeolitized) }\end{array}$ & $\begin{array}{l}\text { Lava-flow aquifer; } \\
\text { welded-tuff aquifer }\end{array}$ & $\begin{array}{l}\text { Major aquifers in eastem Pahute Mesa } \\
\text { [AFFCR, OV?] }\end{array}$ \\
\hline & Grouse Canyon Tuff & $\begin{array}{l}\text { Peralkaline welded ash-flow } \\
\text { tuff (nonwelded tuff, } \\
\text { commonly zeolitized) }\end{array}$ & $\begin{array}{l}\text { Welded-tuff aquifer } \\
\text { (tuff confining unit) }\end{array}$ & $\begin{array}{l}\text { Local aquifer in Yucca Flat and Pahute } \\
\text { Mesa [AFFCR, AM, OV] }\end{array}$ \\
\hline $\begin{array}{l}\text { Tunnel Formation } \\
\text { [Tn] } \\
\text { about } 14 \mathrm{Ma}\end{array}$ & & $\begin{array}{l}\text { Nonwelded tuff, commonly } \\
\text { zeolitized }\end{array}$ & Tuff confining unit & $\begin{array}{l}\text { Major confining unit in Rainier Mesa and } \\
\text { Yucca Flat; contains perched water at } \\
\text { Rainier Mesa [AFFCR, AM] }\end{array}$ \\
\hline $\begin{array}{l}\text { Older volcanics } \\
\text { [To] } \\
16-15 \mathrm{Ma}\end{array}$ & $\begin{array}{l}\text { Red Rock Valley } \\
\text { Tuff, Fraction } \\
\text { Tuff, and pre- } \\
\text { fraction tuffs }\end{array}$ & $\begin{array}{l}\text { Variably welded ash-flow tuff; } \\
\text { nonwelded tuff, commonly } \\
\text { zeolitized }\end{array}$ & $\begin{array}{l}\text { Tuff confining unit } \\
\text { (welded-tuff } \\
\text { aquifer) }\end{array}$ & $\begin{array}{l}\text { Major confining unit where nonwelded in } \\
\text { southern Yucca Flat and Frenchman Flat; } \\
\text { local aquifers in northern Yucca Flat, } \\
\text { southern Rainier Mesa, and parts of } \\
\text { Pahute Mesa. Unit locally includes ash- } \\
\text { flow tuffs of older mid-Tertiary volcanic } \\
\text { centers [AFFCR, AM] }\end{array}$ \\
\hline \multicolumn{2}{|l|}{$\begin{array}{l}\text { Pavits Spring Formation } \\
\text { [Ts] } \\
\text { Miocene }\end{array}$} & $\begin{array}{l}\text { Tuffaceous sandstone; local } \\
\text { conglomerate and siltstone } \\
\text { (ash-fall tuff; lacustrine } \\
\text { limestone) }\end{array}$ & $\mathrm{n} / \mathrm{c}$ & $\begin{array}{l}\text { Significance unknown; mapped as an infor- } \\
\text { mal unit east, south, and west of French- } \\
\text { man Flat; partly coeval with some other } \\
\text { volcanic units [AM] }\end{array}$ \\
\hline \multicolumn{2}{|l|}{$\begin{array}{l}\text { Horse Spring Formation } \\
\text { [Ts] } \\
\text { mid-Tertiary }\end{array}$} & $\begin{array}{l}\text { Conglomerate and tuffaceous } \\
\text { sandstone (lacustrine } \\
\text { limestone; ash-fall tuff) }\end{array}$ & $\mathrm{n} / \mathrm{c}$ & $\begin{array}{l}\text { Significance unknown; mapped as an infor- } \\
\text { mal unit south and west of Frenchman } \\
\text { Flat along Rock Valley fault system [AM] }\end{array}$ \\
\hline
\end{tabular}


Table 1. Principal stratigraphic and associated hydrogeologic units of Nevada Test Site and vicinity-Continued

\begin{tabular}{|c|c|c|c|}
\hline Stratigraphic unit ${ }^{1}$ & Principal lithology 2 & Hydrogeologic unit ${ }^{3}$ & $\begin{array}{l}\text { Known or inferred } \\
\text { hydrologic significance }\end{array}$ \\
\hline $\begin{array}{l}\text { Paleocolluvium } \\
\text { [Tx] } \\
\text { Tertiary }\end{array}$ & Sedimentary breccia & $\mathrm{n} / \mathrm{c}$ & $\begin{array}{l}\text { Locally very porous; thickness variable } \\
\text { along basal contact of Tertiary section; } \\
\text { only known from Yucca Flat and Rainier } \\
\text { Mesa areas; hydrologic significance } \\
\text { uncertain but known to act as a local con- } \\
\text { fining unit in Yucca Flat [AM, AFFCR] }\end{array}$ \\
\hline $\begin{array}{l}\text { Granite } \\
{[\mathrm{Kg}]} \\
\text { Cretaceous }\end{array}$ & Porphyritic monzogranite & $\mathrm{n} / \mathrm{c}$ & $\begin{array}{l}\text { Relatively impermeable; forms local cylin- } \\
\text { drical stocks north of Rainier Mesa and } \\
\text { Yucca Flat; locally yields water from frac- } \\
\text { ture zones [AFFCR, AM] }\end{array}$ \\
\hline $\begin{array}{l}\text { Tippipah Limestone } \\
\text { [P[Pt] } \\
\text { Chiefly Pennsylvanian }\end{array}$ & $\begin{array}{l}\text { Thin-bedded limestone } \\
\text { (pebble conglomerate) }\end{array}$ & $\begin{array}{l}\text { Upper carbonate-rock } \\
\text { aquifer }\end{array}$ & $\begin{array}{l}\text { Local aquifer in western Yucca Flat; limited } \\
\text { lateral extent [AM] }\end{array}$ \\
\hline $\begin{array}{l}\text { Eleana Formation } \\
\text { [MDe] } \\
\text { and Chainman Shale } \\
\text { [Mch] } \\
\text { Chiefly Mississippian }\end{array}$ & $\begin{array}{l}\text { Siliceous siltstone; chert } \\
\text { sandstone; cobble } \\
\text { conglomerate (shale; } \\
\text { quartzite; bioclastic } \\
\text { limestone) }\end{array}$ & Eleana confining unit & $\begin{array}{l}\text { Major confining unit along boundary } \\
\text { between AFFCR and AM subbasins in } \\
\text { western Yucca Flat and northern Jackass } \\
\text { Flats; saturated thickness variable and can } \\
\text { exceed 5,000 ft at some locations; locally } \\
\text { yields water from fracture zones in quartz- } \\
\text { ite and limestone [AFFCR, AM] }\end{array}$ \\
\hline $\begin{array}{l}\text { Guilmette Formation } \\
\text { [Dg] } \\
\text { Devonian }\end{array}$ & $\begin{array}{l}\text { Limestone, locally sandy and } \\
\text { dolomitic }\end{array}$ & & \\
\hline $\begin{array}{l}\text { Simonson Dolomite } \\
\text { [Ds] } \\
\text { Devonian }\end{array}$ & $\begin{array}{l}\text { Dolomite, locally silty or } \\
\text { cherty }\end{array}$ & & $\begin{array}{l}\text { Regional carbonate-rock aquifer; saturated } \\
\text { thickness can exceed 15,000 ft; conveys } \\
\text { most ground water in Yucca Flat-French- }\end{array}$ \\
\hline $\begin{array}{l}\text { Sevy, Laketown, and Lone Mountain Dolomite; } \\
\text { Roberts Mountain Formation; dolomite of } \\
\text { Spotted Range } \\
\text { [various symbols] } \\
\text { Chiefiy Silurian and Devonian }\end{array}$ & $\begin{array}{l}\text { Dolomite, locally silty or } \\
\text { cherty }\end{array}$ & & $\begin{array}{l}\text { system; principal aquifer throughout Ash } \\
\text { Meadows subbasin; significant aquifer in } \\
\text { southern part of Yucca Mountain and } \\
\text { south into AFFCR subbasin [AM, } \\
\text { AFFCR] }\end{array}$ \\
\hline $\begin{array}{l}\text { Ely Springs Dolomite } \\
\text { [Oes] } \\
\text { Ordovician }\end{array}$ & Dolomite, cherty dolomite & & \\
\hline $\begin{array}{l}\text { Eureka Quartzite } \\
\text { [Oe] } \\
\text { Ordovician }\end{array}$ & Siliceous orthoquartzite & $\begin{array}{l}\text { Lower carbonate-rock } \\
\text { aquifer }\end{array}$ & \\
\hline $\begin{array}{l}\text { Pogonip Group } \\
\text { [Op] } \\
\text { Ordovician }\end{array}$ & $\begin{array}{l}\text { Limestone and silty } \\
\text { limestone (dolomite) }\end{array}$ & & $\begin{array}{l}\text { Due to displacement on low-angle faults, } \\
\text { carbonate rocks of these stratigraphic }\end{array}$ \\
\hline $\begin{array}{l}\text { Nopah Formation } \\
\text { [En] } \\
\text { Cambrian }\end{array}$ & $\begin{array}{l}\text { Limestone and dolomite, } \\
\text { locally cherty and silty; } \\
\text { Dunderberg Shale at base }\end{array}$ & & $\begin{array}{l}\text { order above Eleana Formation or Chain- } \\
\text { man Shale; in such situations, structural } \\
\text { blocks of these units do not form lower }\end{array}$ \\
\hline $\begin{array}{l}\text { Bonanza King Formation } \\
\text { [€bk] } \\
\text { Cambrian }\end{array}$ & $\begin{array}{l}\text { Dolomite and limestone (silty } \\
\text { dolomite; chert) }\end{array}$ & & $\begin{array}{l}\text { carbonate-rock aquifer, but rather act sim- } \\
\text { ilar to upper carbonate-rock aquifer }\end{array}$ \\
\hline $\begin{array}{l}\text { Carrara Formation } \\
{[€ c]} \\
\text { Cambrian }\end{array}$ & Liméstone and silty limestone & & a \\
\hline
\end{tabular}


Table 1. Principal stratigraphic and associated hydrogeologic units of Nevada Test Site and vicinity-Continued

\begin{tabular}{|c|c|c|c|c|}
\hline \multicolumn{2}{|c|}{ Stratigraphic unit ${ }^{1}$} & Principal lithology 2 & Hydrogeologile unit ${ }^{3}$ & $\begin{array}{c}\text { Known or inferred } \\
\text { hydrologic significance }\end{array}$ \\
\hline $\begin{array}{l}\text { Carrara Formation } \\
\text { [€c] } \\
\text { Cambrian }\end{array}$ & [lower part] & $\begin{array}{l}\text { Shale and siltstone } \\
\text { (limestone and quartzite) }\end{array}$ & \multirow{4}{*}{$\begin{array}{l}\text { Quartzite confining } \\
\text { unit }\end{array}$} & \multirow{4}{*}{$\begin{array}{l}\text { Widespread confining unit that forms hydro- } \\
\text { logic basement throughout much of south- } \\
\text { ern Nevada; saturated thickness can } \\
\text { exceed } 10,000 \mathrm{ft} \text {; forms major barrier to } \\
\text { lateral ground-water flow in northeastern } \\
\text { Yucca Flat, south of Oasis Valley near } \\
\text { Beatty, and south of Ash Meadows; } \\
\text { locally yields substantial water from frac- } \\
\text { tured quartzite or fault zones in northern } \\
\text { Yucca Flat [OV, AFFCR, AM] }\end{array}$} \\
\hline $\begin{array}{l}\text { Zabriskie Quartzite } \\
\text { [€z] } \\
\text { Cambrian } \\
\end{array}$ & & Siliceous orthoquartzite & & \\
\hline \multicolumn{2}{|c|}{$\begin{array}{l}\text { Wood Canyon Formation } \\
{[€ Z w]} \\
\text { Cambrian and Eocambrian }\end{array}$} & $\begin{array}{l}\text { Micaceous siltstone and } \\
\text { orthoquartzite (dolomite; } \\
\text { pebbly quartzite) }\end{array}$ & & \\
\hline \multicolumn{2}{|l|}{$\begin{array}{l}\text { Stirling Quartzite } \\
\text { [Zs] } \\
\text { Eocambrian }\end{array}$} & $\begin{array}{l}\text { Siliceous orthoquartzite and } \\
\text { micaceous siltstone } \\
\text { (quartzite conglomerate) }\end{array}$ & & \\
\hline \multicolumn{2}{|l|}{$\begin{array}{l}\text { Noonday Dolomite } \\
\text { [Zn?] } \\
\text { Eocambrian }\end{array}$} & Dolomite & $\mathrm{n} / \mathrm{c}$ & $\begin{array}{l}\text { Known only from bottom of deep drillhole } \\
\text { UE-15d in northern Yucca Flat; strati- } \\
\text { graphic identity uncertain (Barnes, 1962) }\end{array}$ \\
\hline
\end{tabular}

${ }^{1}$ Map symbol shown in brackets. Approximate age given in millions of years ago (Ma) or indicated by geologic system.

${ }^{2}$ Rock type listed in order of decreasing prevalence; minor but significant rock types listed in parentheses.

${ }^{3}$ Hydrogeologic units in order of decreasing prevalence. Stratigraphic classification of Tertiary volcanic rocks is based on age and composition. Lithologic and hydrologic properties may be extremely variable from place to place. n/c, stratigraphic unit has not been characterized as a hydrogeologic unit, generally because its presence in the unsaturated zone is minor.

${ }^{4}$ Code in brackets at end of entry gives ground-water subbasin or subbasins in which stratigraphic units is prevalent. AFFCR, Alkali Flat-Furnace Creek Ranch; AM, Ash Meadows; and OV, Oasis Valley. Query indicates uncertainty regarding presence or significance of unit in subbasin.

Table 2. Nomenclature for hydrogeologic units of Nevada Test Site and vicinity

\begin{tabular}{|c|c|c|}
\hline $\begin{array}{c}\text { Regional } \\
\text { hydrogeologic unit }\end{array}$ & $\begin{array}{c}\text { Subregional } \\
\text { hydrogeologlc unit }\end{array}$ & $\begin{array}{l}\text { Equivalent previous units } \\
\text { (Winograd and Thordarson, 1975) }\end{array}$ \\
\hline Valley-fill aquifer & Valley-fill aquifer ${ }^{1}$ & Valley-fill aquifer \\
\hline \multirow[t]{2}{*}{ Volcanic-rock aquifer } & Welded-tuff aquifer ${ }^{1}$ & $\begin{array}{l}\text { Welded-tuff aquifer } \\
\text { Bedded-tuff aquifer }\end{array}$ \\
\hline & Lava-flow aquifer & Lava-flow aquifer \\
\hline Volcanic confining unit & Tuff confining unit ${ }^{1}$ & $\begin{array}{c}\text { Tuff aquitard } \\
\text { Lava-flow aquitard }\end{array}$ \\
\hline$N / R^{2}$ & Granite $^{1}$ & Minor aquitard \\
\hline $\mathrm{N} / \mathrm{R}^{2}$ & Upper carbonate-rock aquifer ${ }^{1}$ & Upper carbonate-rock aquifer \\
\hline Eleana confining unit & Eleana confining unit & Upper clastic aquitard \\
\hline Carbonate-rock aquifer & Lower carbonate-rock aquifer & Lower carbonate-rock aquifer \\
\hline Basement confining unit & Quartzite confining unit & Lower clastic aquitard \\
\hline
\end{tabular}

${ }^{1}$ Due to original lenticular or interlayed form of constituent rock bodies, or due to geometric modifications caused by faulting or folding, or both, these hydrogeologic units generally consist of more than one disconnected or partially connected aquifer or confining unit.

${ }^{2} \mathrm{~N} / \mathrm{R}$, no regional hydrogeologic unit is recognized because corresponding subregional units have limited areal extent and do not substantially effect regional ground-water flow. 
Ranges, the northwestern Spring Mountains, and the north end of Bare Mountain, the quartzite confining unit impedes the movement of ground water (Winograd and Thordarson, 1975, pl. 1). Its effectiveness as a barrier is evidenced by steep hydraulic gradients across these exposures (pl. 1; Waddell and others, 1984, pl. 3).

Cambrian through Devonian rocks that make up the lower (regional) carbonate-rock aquifer consist of $15,000 \mathrm{ft}$ of dolomite, interbedded limestone, and thin but persistent shale and quartzite layers. These carbonate rocks are the most transmissive materials within the Death Valley flow system because they are soluble in ground water (Dettinger, 1989, p. 5) and because late Cenozoic tectonic activity in the region has created abundant secondary permeability in fractures (Winograd and Thordarson, 1975, p. 74). This aquifer is particularly important to the movement of water between the underground test areas of Yucca and Frenchman Flats and discharge areas in Ash Meadows and Death Valley (fig. 4). Thin confining beds contained within the aquifer, such as the Dunderberg Shale and Eureka Quartzite (table 1), do not appear to be regionally effective confining units because faulting has disrupted their continuity; however, they may impede ground-water flow locally (Winograd and Thordarson, 1975, p. 74).

Whereas the quartzite confining unit and the lower carbonate-rock aquifer are regionally extensive, the Eleana confining unit forms a narrow arcuate band in the subsurface that persists along the west side of Yucca Flat to CP Hills, where it swings westward across northern Jackass Flats and the north end of Yucca Mountain to Bare Mountain (fig. 4). The Eleana Formation, for which the unit is named, consists of low-permeability siliceous siltstone, sandstone, and conglomerate (minor limestone) that may be as thick as $6,500 \mathrm{ft}$ along the axis of the arc. The Eleana Formation grades laterally into the Chainman Shale (possibly 4,000 ft thick; Cole and others, 1994) toward the east and south as a result of primary depositional facies trends. Rocks of equivalent Mississippian age near Mercury are less than $1,300 \mathrm{ft}$ thick and composed chiefly of limestone that was deposited on a carbonate bank (Poole and others, 1961; Barnes and others, 1982).

Two assemblages of rocks, designated as the upper carbonate-rock aquifer, are present in a few locations within the Death Valley ground-water flow system and probably do not exert significant control on the regional flow of ground water in the NTS region.
One assemblage consists of Pennsylvanian limestone (Tippipah Limestone in table 1) that depositionally overlies the Chainman Shale in the core of a syncline along the western margin of Yucca Flat. The second assemblage consists of older heterogeneous carbonate rocks that lie structurally above the Eleana confining unit as a result of thrust faulting or low angle normal faulting (Cole and others, 1990, 1994). The lateral extent and hydraulic connection of these rock assemblages are largely unknown. In many locations east and south of NTS, the Eleana confining unit is not present and all Paleozoic carbonate rocks, regardless of age, function as a single integrated hydrogeologic unit and are collectively denoted the regional carbonate-rock aquifer in this report.

The rocks that make up the volcanic aquifers and volcanic confining units generally are restricted geographically to the area of the southwest Nevada volcanic field (fig. 4). This Miocene rhyolitic eruptive center produced an overlapping complex of roughly cylindrical caldera vents in the general area of Timber Mountain and Pahute Mesa, and laterally extensive tabular outflow sheets of welded tuff (Byers and others, 1976). Water-bearing properties of these volcanic deposits are governed chiefly by the mode of eruption and cooling, by the extent of primary and secondary fracturing, and by the degree to which secondary alteration (crystallization of volcanic glass and zeolite alteration) have affected primary permeability. The volcanic units, therefore, tend to be geometrically complex, and their hydrologic characteristics more difficult to predict than the pre-Tertiary sedimentary rocks, because stratigraphic position does not correlate with hydrologic properties (table 1). Dense rocks with abundant fractures make up the main elements of the volcanic aquifers, which consist of welded-tuff sheets outside the calderas and lava flows and thick welded-tuff bodies within the calderas. The confining units are formed generally by the zeolitically altered nonwelded-tuff units, which are more common in the older, deeper parts of the volcanic section (Winograd and Thordarson, 1975, p. 44; Byers and others, 1976).

Valley-fill aquifers are formed by detrital gravel and sand that fill modern basins of the area. These aquifers are characterized by high porosity and permeability where saturated, but few basins are deep enough that a significant volume of alluvium is beneath the water table. Downgradient from NTS testing areas, the alluvium is saturated only in central and southern Yucca Flat, in Frenchman Flat, in Jackass Flats, and in 
the Amargosa Desert. The valley-fill aquifer may be important in Oasis Valley, southwest of the Pahute Mesa test area, but little is known of the subsurface geology.

\section{Ground-Water Flow and Subbasins}

Regional interpretations of ground-water flow within the NTS area are based on the concept of ground-water subbasins. A ground-water subbasin defines the area that contributes water to a major surface discharge. Subbasins are delineated primarily on the basis of (1) the location of major discharge areas (springs and wet playas), (2) the location of recharge areas (zones of substantial precipitation), (3) occurrences of rocks with low water-transmitting potential (low permeability), (4) regional hydraulic gradients determined from measurements of water level, and (5) comparisons of the chemical and isotopic composition of water. Ground-water levels near NTS range in altitude from about $6,000 \mathrm{ft}$ beneath the Kawich Range to below sea level at Death Valley (pl. 1). Four major areas of ground-water discharge are downgradient of NTS-the Oasis Valley and Ash Meadows discharge areas in Nevada, and the Alkali Flat and Death Valley (Furnace Creek Ranch) discharge areas in California.

Ground water beneath NTS is likely to flow to each of the discharge areas mentioned above. Three principal ground-water subbasins were identified within the NTS region by Waddell and others (1984, p. 36). The subbasins, named for their downgradient discharge areas, are (1) Ash Meadows, (2) Oasis Valley, and (3) Alkali Flat-Furnace Creek Ranch (pl. 1). Subbasin delineation is based on sparse and inconsistent data and the exact location of subbasin boundaries is not known precisely. Subbasins, as shown on plate 1 , are intended only to illustrate regional flow concepts, and should not be used to infer or estimate specific flow paths. The general characteristics of each subbasin are summarized in table 3.

\section{Ash Meadows Subbasin}

The Ash Meadows subbasin includes the eastern half of NTS and adjoins the Alkali Flat-Furnace Creek Ranch subbasin along its western boundary (pl. 1). The subbasin covers an area of about $4,000 \mathrm{mi}^{2}$ that includes Yucca Flat, Frenchman Flat, and parts of Shoshone Mountain and Rainier Mesa underground test areas (fig. 2). The regional carbonate-rock aquifer is the major aquifer in the subbasin (pls. 1 and 2), although the valley-fill aquifer in the Ash Meadows region and the valley-fill and volcanic aquifers at Emigrant Valley, Yucca Flat, and Frenchman Flat also are important locally.

Ground water in the subbasin discharges at Ash Meadows from a line of springs about $10 \mathrm{mi}$ long that generally coincides with the trace of a buried fault. The spring line is about $40 \mathrm{mi}$ downgradient of the Yucca Flat underground test area. Springflow has been estimated at 17,000 acre-ft/yr (Walker and Eakin, 1963, p. 21-24; Winograd and Thordarson, 1975, p. 78). These springs support many plants indigenous to this area only. Devils Hole, a collapse feature along a local fault, provides the only natural habitat for the endangered Devils Hole pupfish.

Water also leaves the subbasin through evapotranspiration (pls. 1 and 2). Annual evapotranspiration from the Ash Meadows area has been estimated at 10,500 acre-ft (Walker and Eakin, 1963, p. 21-24; Winograd and Thordarson, 1975, p. 84). The estimate is based on transpiration rates determined for similar phreatophytes found in other arid regions. Winograd and Thordarson (1975, p. 84) suggest that the source of evapotranspired water is primarily recycled springflow; but they do not dismiss the possibility that some ground water available to plants in the areas may be derived instead by shallow ground water fed by upflow from the underlying carbonate-rock aquifer, nor do they reject the possibility that their estimates of annual transpiration may be low. Another likely area of evapotranspiration is northeast of Ash Meadows around Amargosa Flat (fig. 1, pl. 1). Here, like Ash Meadows, the water table is less than a few tens of feet and is in the valley-fill aquifer. Water levels are maintained primarily by upflow from the underlying carbonate-rock aquifer. The community of phreatophytes present around the eastern edge of the playa are supported by, and transpire, the shallow ground water. Although evapotranspiration has not been directly quantified from this area, Winograd and Thordarson (1975, p. 84-85) believe annual upflow into the valley-fill aquifer to be less than 1,000 acre-ft.

Ground water is withdrawn from wells scattered throughout the Ash Meadows subbasin. Pumped wells on NTS within the subbasin are used to withdraw about 50 percent of the facility's total water needs 
Table 3. General characteristics of ground-water subbasins of Nevada Test Site and vicinity

[NTS, Nevada Test Site]

\begin{tabular}{|c|c|c|c|c|c|}
\hline $\begin{array}{l}\text { Ground-water } \\
\text { subbasin }\end{array}$ & $\begin{array}{c}\text { Surface area } \\
\text { (square miles) }\end{array}$ & $\begin{array}{l}\text { Relation to NTS } \\
\text { underground test areas }\end{array}$ & $\begin{array}{l}\text { Principal water- } \\
\text { bearing rocks }\end{array}$ & Inflow' & Outflow 1 \\
\hline $\begin{array}{l}\text { Oasis Valley } \\
\text { [OV] }\end{array}$ & 550 & $\begin{array}{l}\text { Includes westernmost part of } \\
\text { Pahute Mesa test area in } \\
\text { northwestern NTS }\end{array}$ & $\begin{array}{l}\text { Welded tuffs and lava flow; } \\
\text { valley-fill alluvium locally } \\
\text { important at Gold Flat and } \\
\text { Oasis Valley }\end{array}$ & $\begin{array}{l}\text { Precipitation recharge near Black } \\
\text { Mountain; subsurface inflow from } \\
\text { Cactus Flat }\end{array}$ & $\begin{array}{l}\text { Springflow and evapotranspira- } \\
\text { tion at Oasis Valley; subsurface } \\
\text { outflow to AFFCR south of } \\
\text { Beatty, Nev. }\end{array}$ \\
\hline $\begin{array}{l}\text { Alkali Flat-Furnace } \\
\text { Creek Ranch } \\
\text { [AFFCR] }\end{array}$ & 2,800 & $\begin{array}{l}\text { Includes most of Pahute Mesa } \\
\text { and all Buckboard Mesa and } \\
\text { Dome Mountain test areas } \\
\text { in western NTS; Rainier } \\
\text { Mesa and Shoshone } \\
\text { Mountain test areas are } \\
\text { along boundary between } \\
\text { AFFCR and AM }\end{array}$ & $\begin{array}{l}\text { Welded tuffs and lava flows } \\
\text { in test areas; limestone, } \\
\text { dolomite, and valley-fill } \\
\text { alluvium south of test areas } \\
\text { and at discharge area }\end{array}$ & $\begin{array}{l}\text { Precipitation recharge at Belted } \\
\text { Range, Kawich Range, Quinn } \\
\text { Canyon Range, Pahute Mesa, and } \\
\text { Rainier Mesa and possibly at } \\
\text { Timber Mountain and Fortymile } \\
\text { Wash; subsurface inflow from } \\
\text { Cactus Flat and from across } \\
\text { discharge areas of OV and AM }\end{array}$ & $\begin{array}{l}\text { Springflow at Death Valley and } \\
\text { evapotranspiration from Alkali } \\
\text { Flat and Death Valley }\end{array}$ \\
\hline $\begin{array}{l}\text { Ash Meadows } \\
\text { [AM] }\end{array}$ & 4,000 & $\begin{array}{l}\text { Includes all Yucca Flat and } \\
\text { Frenchman Flat test areas in } \\
\text { central, eastern, and southern } \\
\text { NTS; Rainier Mesa and } \\
\text { Shoshone Mountain test } \\
\text { areas are along boundary } \\
\text { between AM and AFFCR }\end{array}$ & $\begin{array}{l}\text { Welded and nonwelded tuffs, } \\
\text { limestone, dolomites and } \\
\text { valley-fill alluvium in test } \\
\text { areas; limestone, dolomite } \\
\text { and valley-fill alluvium } \\
\text { south and west of test areas } \\
\text { and at discharge areas }\end{array}$ & $\begin{array}{l}\text { Precipitation recharge at Belted } \\
\text { Range, Reveille Range, Rainier } \\
\text { Mesa, Timpahute Range, } \\
\text { Pahranagat Range, Sheep Range, } \\
\text { Spring Mountains, and possibly at } \\
\text { Desert Range; subsurface inflow } \\
\text { from Railroad Valley and } \\
\text { Pahranagat Valley }\end{array}$ & $\begin{array}{l}\text { Springflow and evapotranspira- } \\
\text { tion at Ash Meadows spring } \\
\text { line; subsurface outflow beneath } \\
\text { Ash Meadows to AFFCR }\end{array}$ \\
\hline
\end{tabular}

${ }^{1}$ Based on information from Winograd and Thordarson (1975), Waddell and others (1984), and Harrill and others (1988). 
(D.B. Wood, U.S. Geological Survey, written commun., 1992). Downgradient of NTS, only a few wells withdraw water-primarily for domestic purposes.

Precipitation recharges the subbasin along its northern boundary at the Belted, Reveille, Timpahute, and Pahranagat Ranges, along its eastern boundary at the Sheep Range; and along its southern boundary at the Spring Mountains. Recharge also may occur within the subbasin at higher mountains of the Spotted, Pintwater, and Desert Ranges. Such a distribution of recharge requires water to move long distances through differing geologic environments before reaching Ash Meadows. The mixed ionic and isotopic composition of the springflow at Ash Meadows is supportive of water originating or passing through differing rock types (Winograd and Friedman, 1972; Winograd and Pearson, 1976, p. 1130; Peterman and others, 1990).

Regional hydraulic gradients based on waterlevel data indicate that water moves away from these recharge areas toward Frenchman Flat, and then flows southwest through the regional carbonate-rock aquifer toward the Ash Meadows discharge area (pls. 1 and 2). At Ash Meadows, water is diverted up to the surface by the presence of low-permeability rocks brought into contact with the regional carbonate-rock aquifer by a major buried fault (Dudley and Larson, 1976, p. 9-10). The valley-fill and volcanic aquifers in Emigrant Valley, Yucca Flat, and Frenchman Flat provide local recharge to the regional carbonate-rock aquifer (Winograd and Thordarson, 1975, p. 49-62).

The location of subbasin boundary is based on limited hydrogeologic information, and thus, is the subject of differing scientific opinion. Other studies have proposed locations somewhat different from those shown on plate 1. Prudic and others (1995, p. 63) placed the eastern boundary of the subbasin further west along the Pintwater Range, thus excluding recharge from the Sheep Range. Others have included eastern Jackass Flats within the Ash Meadows subbasin on the premise that water from eastern Jackass Flats and Rock Valley flows south toward Ash Meadows through faults in the basement confining unit beneath Skeleton Hills and Specter Range (Winograd and Thordarson, 1975, pl. 1).

Subsurface flow into the subbasin from across its boundary is likely, although few quantitative estimates are available. Inflow to the subbasin from Pahrump Valley to the south had been proposed by Hunt and others (1966, p. 28), but subsequently has been determined doubtful by Winograd and Thordarson $(1975$, p. 108), who base their conclusion primarily on the presence of the basement confining unit at relatively shallow depths. They further support their conclusion on the basis of water chemistry contrasts: larger percentages of sodium, potassium, chloride, and sulfate in Ash Meadows water relative to Pahrump Valley water and large differences in the deuterium content of water sampled from the two areas (Winograd and Friedman, 1972, p. 3701). Deuterium data also were used by these same investigators to support inflow (up to 35 percent of the total estimated discharge at Ash Meadows) from Pahranagat Valley northeast of the subbasin (fig. 1). Inflow from Pahranagat Valley also is supported by other investigators using isotope and other chemical data (Thomas, 1988; Sadler and others, 1992, table 1), but is not supported by flow model results presented by Prudic and others (1995, p. 63). Minor inflow from the west across the Eleana confining unit and the carbonate rocks that underlie the confining unit at depth also has been suggested by Winograd and Thordarson (1975, p. 93) and Feeney and others (1987, fig. 6).

Subsurface outflow into the Alkali Flat-Furnace Creek Ranch subbasin from rocks beneath the Ash Meadows spring line is probable. Estimated rates of subsurface outflow are few. Flow models have simulated rates that range between 0 and about 23 acre-ft/yr (Czarnecki and Waddell, 1984, table 1; Prudic and others, 1995, p. 62). Outflow across the boundary may occur diffusely across the fault zone that juxtaposes lower permeability Cenozoic rocks against the regional carbonate-rock aquifer, or possibly through carbonate rocks that may be in direct contact across this fault at depth, or both (pl. 1). Subsurface outflow is supported by geochemical data that indicate a similar isotopic and chemical composition for water sampled from the carbonate-rock aquifer in central Amargosa Desert and at springs near Death Valley and Ash Meadows (Winograd and Friedman, 1972, p. 3704; Winograd and Thordarson, 1975, p. 112).

\section{Oasis Valley Subbasin}

The Oasis Valley subbasin is the smallest and most western of the three subbasins (pl. 1). The subbasin measures about $550 \mathrm{mi}^{2}$ and extends north from Oasis Valley to include the western part of Gold Flat, Black Mountain, and parts of western and central Pahute Mesa. The subbasin adjoins the Alkali FlatFurnace Creek Ranch subbasin on the east and includes the western part of the Pahute Mesa underground test 
area (pl. 1, fig. 2). Volcanic rocks are the dominant hydrogeologic units within the subbasin, although some alluvium is saturated in Gold Flat and Oasis Valley.

Ground water discharges from the Oasis Valley subbasin as springflow and evapotranspiration, primarily at and along the flood plain of the Amargosa River and tributary drainages within Oasis Valley south to Beatty, Nev. The discharge area starts about $17 \mathrm{mi}$ southwest of an area of past underground testing on Pahute Mesa. Discharge has been estimated at 2,000 acre-ft/yr by Malmberg and Eakin (1962, p. 25) on the basis of transpiration rates determined for similar phreatophyte assemblages in other arid regions. Blankennagel and Weir (1973, p. 21) state that other estimates, although unpublished and derived in part on the basis of total springflow, suggest discharge rates possibly two to three times higher.

The basin provides water to ranches in upper Oasis Valley and residents of Springdale, Nev. Ground water also is used by residents of Beatty, Nev., but its use is limited by fluoride concentrations in wells and springs, which often exceed the maximum permitted value.

Precipitation recharges the subbasin primarily along its northern boundary at the Cactus Range. Recharge from within the subbasin may occur at Black Mountain, Quartz Mountain, and Pahute Mesa. Water also enters the subbasin from the north beneath Cactus Flat as subsurface inflow. Hydraulic gradients based on regional water-level data indicate that ground water flows primarily south-southwestward through western Gold Flat and central Pahute Mesa and into Oasis Valley (pl. 1). At Oasis Valley, water moving southward is thought to be diverted upward by the basement confining unit, which is exposed nearby in Bullfrog Hills and in the northern part of Bare Mountain, and brought to the surface along faults. However, specific controls on discharge are not known.

The boundary of the Oasis Valley subbasin is not well defined. As shown in plate 1, the northern part of the eastern boundary coincides approximately with a limited-flow barrier suggested by Blankennagel and Weir (1973, pl. 1). Other interpretations regard this barrier as a local feature, and extend the eastern boundary as far east as the Kawich Range, thus including more of the Pahute Mesa test area, Timber Mountain, and Gold Flat within the subbasin (Malmberg and Eakin, 1962, pl. 3; Borg and others, 1976; White, 1979; White and Chuma, 1987). The location of this boundary influences the interpretation of which, if any, tests at Pahute Mesa could contribute contaminated water to Oasis Valley.

Outflow from beneath Oasis Valley into the Alkali Flat-Furnace Creek Ranch subbasin is supported in the literature, but few quantitative estimates are given. Malmberg and Eakin (1962, p. 26) estimate ground-water outflow at 400 acre-ft/yr through a narrow veneer of valley fill that overlies the basement confining unit along the Amargosa River south of Beatty, Nev. Some outflow also may move into the low-permeability rocks that make up the basement confining unit.

\section{Alkali Flat-Furnace Creek Ranch Subbasin}

The Alkali Flat-Furnace Creek Ranch subbasin lies between the Ash Meadows and Oasis Valley subbasins (pl. 1). The subbasin is about $2,800 \mathrm{mi}^{2}$ and covers a large part of the western half of NTS, including parts of Rainier Mesa, Pahute Mesa, and Shoshone Mountain underground test areas (pl. 1, fig 2). The subbasin is bounded on the north by hydrologic divides associated with recharge areas, on the east by a recharge divide and the Eleana confining unit, and locally on the west by subsurface structures that probably coincide with caldera-boundary faults. The principal aquifers in the northern part of the subbasin are volcanic aquifers, whereas valley-fill and carbonaterock aquifers dominate in the southern part. Volcanic rocks in the eastern half of the northern part of the subbasin are underlain by Paleozoic clastic and carbonate rocks.

Ground water discharges from the Alkali FlatFurnace Creek Ranch subbasin primarily as evaporation from Alkali Flat and as springflow and evapotranspiration near Furnace Creek Ranch in Death Valley. The subbasin provides about 50 percent of the NTS water supply (D.B. Wood, U.S. Geological Survey, written commun., 1992). Downgradient of NTS, the subbasin supplies water to the rural communities of Amargosa Valley, Nev., and Death Valley Junction, Calif., to a few ranches, farms, and mining operations within the Amargosa Desert, and to private recreational establishments and Federal facilities within the Death Valley National Park, Calif. Springflow from the subbasin is a major source of water supporting the plant and wildlife within Death Valley. Discharge from the subbasin is difficult to separate from total discharge throughout the Death Valley region. Waddell and 
others (1984, p. 38) estimate discharge from the subba$\sin$ at about 15,600 acre-ft/yr. Of this total, about 10,000 acre-ft/yr (Walker and Eakin, 1963) discharges at Alkali Flat and the remainder from springs and as evaporation near Furnace Creek Ranch in Death Valley.

Precipitation recharges the subbasin along its northern boundary at Kawich Range and Reveille Range, and along the northeastern boundary at Belted Range, Rainier Mesa, and Shoshone Mountain. Recharge occurs from within the subbasin throughout eastern Pahute Mesa and at the southern part of Kawich Range. Precipitation falling on Timber Mountain and the Funeral Mountains also may contribute some recharge to the subbasin. Infiltration of surface runoff in the upper reaches of Fortymile Wash drainage during periods of moderate to intense precipitation has been proposed as another potential source of recharge (Czarnecki and Waddell, 1984, p. 10; Claassen, 1985, p. 21).

Hydraulic gradients based on sparse water-level measurements indicate that the principal flow direction in the upgradient part of the Alkali Flat-Furnace Creek Ranch subbasin is southward across eastern Pahute Mesa and western Rainier Mesa (pl. 1). Data are insufficient to determine whether flow continues southward across Timber Mountain or is diverted around it toward western Shoshone Mountain, Yucca Mountain, and Jackass Flats into the Amargosa Desert. From the Amargosa Desert, water flows either southward into Alkali Flat or southwest across the Funeral Mountains into Death Valley. At Alkali Flat, water flowing southward is deflected to the southwest toward Death Valley or toward the surface by the basement confining unit beneath Eagle Mountain and Resting Spring Range. Some water flowing westward across the Amargosa Desert and beneath the Funeral Mountains is diverted to the surface either by contact with less-permeable lakebed and eolian deposits or by the basement confining unit. The remaining water flows into Death Valley and is discharged as springflow and through evaporative processes.

As with the other subbasins, the location of the Alkali Flat-Furnace Creek Ranch subbasin boundary is neither well established nor fully understood. Flow across the boundary, where common to Oasis Valley and Ash Meadows subbasins, was discussed previously in the respective subbasin sections. Subsurface inflow from Cactus Flat and Reveille Valley may occur across the northern boundary. Subsurface outflow across the southern boundary into a downgradient subbasin of the
Death Valley ground-water flow system is estimated at 500 acre-ft/yr (Walker and Eakin, 1963, p. 22; Waddell and others, 1984, p. 38). Outflow across this boundary could occur through the basement confining unit beneath Eagle Mountain or through a veneer of valley fill along the Amargosa River, or both. The location of the southern part of the western boundary is highly subjective. The reach of Amargosa River south of Beatty, Nev., and west of Bare Mountain is included within the subbasin. The position of this boundary implies that water beneath this area flows southeast, either through a thin section of valley-fill and volcanic aquifers beneath the Amargosa Desert or the underlying basement confining unit.

\section{Flow Rates and Summary}

The rates of ground-water flow through these subbasins are highly variable. A few estimates are given in the literature. These estimates are based on (1) an analysis of regional water budgets in Pahute Mesa by Blankennagel and Weir (1973, p. 24-25) and in Yucca Flat by Winograd and Thordarson (1975, p. 113-116); (2) an analysis of regional isotope (natural tracer) chemistries in the Alkali Flat-Furnace Creek Ranch subbasin downgradient of Yucca Mountain (Claassen, 1985, p. 29) and in the carbonate-rock aquifer beneath Yucca Flat (Winograd and Pearson, 1976); and (3) forced-gradient tracer tests in the carbonaterock aquifer beneath the Amargosa Desert upgradient of Ash Meadows (Claassen and Cordes, 1975). Estimates differ by orders of magnitude, ranging from less than 0.1 to more than $100 \mathrm{ft} / \mathrm{d}$. In general, results indicate that the regional carbonate-rock aquifer has the potential to transmit water at the fastest rate, the basement and Eleana confining units at the slowest rate, and volcanic and valley-fill aquifers and confining units at rates somewhere in between. Caution must be taken when applying any estimates over large distances because a value is only specific to the area or point at * which it was derived, and the validity of many assumptions inherent in the methods are uncertain.

The regional interpretation presented provides general information about the flow of ground water into, through, and out of NTS. Water enters NTS laterally as subsurface inflow and vertically as recharge from precipitation. Lateral inflow through volcanic aquifers occurs from the north at Gold Flat and Kawich Valley, and through the regional carbonate-rock aquifer from the east and southeast. Precipitation falling on 
eastern Pahute Mesa and Rainier Mesa and possibly Shoshone Mountain and Timber Mountain percolates downward through unsaturated rock, locally recharging the ground-water flow system. Ground-water leaves NTS primarily along its western and southern boundaries flowing toward one of the major discharge areas. This interpretation is highly generalized and does not define specific subsurface paths through which water flows or through which a contaminant may be transported, nor does it describe the spatial variability of the physical and chemical properties that control the rate at which ground water or a contaminant moves along a flow path. The following section provides a more detailed description of ground-water flow in the major areas of underground testing.

\section{UNDERGROUND TEST AREAS}

The underground testing of nuclear weapons is the principal mechanism by which contaminants have been introduced into the subsurface at NTS. Through September 1992, 828 underground nuclear tests have been detonated (U.S. Department of Energy, 1994). Generally, testing has been confined to specific regions designated as Yucca Flat, Pahute Mesa, Rainier Mesa, Frenchman Flat, Shoshone Mountain, Buckboard Mesa, and Dome Mountain test areas (fig. 2, table 4). The large majority of these tests were detonated in Yucca Flat, Pahute Mesa, and Rainier Mesa.

The effects of detonating a nuclear device underground are complex and are discussed in a later section "Effects of Underground Testing on Ground-Water Flow." Determining locations where test-generated byproducts have contaminated the ground-water flow system are difficult because there exists few measurements or observations of contaminant occurrence. Table 4 provides an estimate of the number of tests that have potentially introduced contaminants into the ground-water flow system. The estimate is based on the depth of tests relative to the pre-test water table and explosive yields, which largely determine the size of the initial cavity that results from instantaneous melting of the surrounding rock. Underground tests detonated below the pre-test water table and those tests whose shock-melt cavity extends to a depth below the pre-test water table are considered certain sources of direct contamination to the ground-water flow system. Underground tests detonated above the water table but within 2 cavity radii of the pre-test water table are considered probable sources of direct ground-water contamination. Underground tests detonated at greater distances above the pre-test water table, but within 2-5 cavity radii may have explosively introduced contaminants into the ground-water flow system and are summed with previous categories to provide a comparative measure of the maximum number of tests likely to have introduced contaminants into the ground-water flow system. Tabulated sums given in table 4 should be viewed as approximations and should not be considered to represent the actual known number. The test areas where test-generated contaminants have the greatest likelihood of being introduced into the groundwater flow system are Yucca Flat, Pahute Mesa, and Frenchman Flat.

The following sections present hydrologic and geologic information pertinent to understanding the likely pathways of ground-water movement within and away from the major test areas. Minor test areas, those where only a few tests were detonated above the water table, are not discussed. Yucca Flat and Frenchman Flat are discussed together on the basis of many hydrogeologic similarities, as are Pahute Mesa and Rainier Mesa.

\section{Yucca Flat and Frenchman Flat}

The Yucca Flat and Frenchman Flat underground test areas (fig. 2) are in topographically closed basins of the same name (basin delineations are approximately equivalent to hydrographic areas ${ }^{1}$ shown on pl. 3) in the eastern part of the NTS and lie entirely within the Ash Meadows ground-water subbasin (table 3 , pls. 2 and 3). Together these basins have provided locations for 671 underground nuclear tests (U.S. Department of Energy, 1994). Of this total, at least 144 and as many as 236 tests were detonated at depths sufficient to have introduced contaminants directly into the ground-water flow system (table 4).

\footnotetext{
${ }^{1}$ Formal hydrographic areas in Nevada were delineated systematically by the U.S. Geological Survey and Nevada Division of Water Resources in the late 1960's (Rush, 1968; Cardinalli and others, 1968) for scientific and administrative purposes. The official hydrographic-area names, numbers, and geographic boundaries continue to be used in Geological Survey scientific reports and Division of Water Resources administrative activities. See index map, plate 1, for hydrographic areas in and near the Nevada Test Site.
} 
Table 4. Distribution of underground tests relative to water table and estimated number of tests that have introduced test-generated contaminants into the ground-water flow system by major test area at the Nevada Test Site

[Working point is depth at which nuclear device is detonated; water table is estimated or measured altitude of regional water table prior to underground test; cavity radius (CR) is estimated or measured radius of cavity formed after underground test (typically determined by post-shot drilling as distance between working point and lower surface of the radioactive glass "puddle" formed in bottom of cavity). Source is U.S. Department of Energy (1994). Calculations based on measurements of cavity radius, and on working-point and static borehole water-level depths, as summarized in classified listing of test parameters (Lawrence Livermore National Laboratory, written commun., 1991).

\begin{tabular}{|c|c|c|c|c|c|c|c|c|}
\hline \multirow[b]{4}{*}{$\begin{array}{c}\text { NTS } \\
\text { area } \\
\text { (figure 2) }\end{array}$} & \multicolumn{8}{|c|}{ Number of underground tests } \\
\hline & \multicolumn{5}{|c|}{ Location of working point relative to water table } & \multirow{2}{*}{\multicolumn{3}{|c|}{$\begin{array}{l}\text { Tests that introduced } \\
\text { contaminants into ground-water } \\
\text { flow system }\end{array}$}} \\
\hline & & \multicolumn{4}{|c|}{ Above } & & & \\
\hline & Below & $\begin{array}{l}\text { Less than } \\
\text { or equal } \\
\text { to CR }\end{array}$ & $\begin{array}{l}\text { Greater than one and } \\
\text { less than or equal } \\
\text { to two CR }\end{array}$ & $\begin{array}{l}\text { Greater than two and } \\
\text { less than or equal } \\
\text { to flve } \mathrm{CR}^{1}\end{array}$ & $\begin{array}{l}\text { Greater } \\
\text { than } \\
\text { flve CR }\end{array}$ & $\begin{array}{l}\text { Certain } \\
\text { or } \\
\text { probable }\end{array}$ & Maximum $^{3}$ & Total $^{4}$ \\
\hline \multicolumn{9}{|c|}{ Yucca Flat } \\
\hline $\begin{array}{l}1 \\
2 \\
3 \\
4 \\
6\end{array}$ & $\begin{array}{r}0 \\
19 \\
9 \\
16 \\
0\end{array}$ & $\begin{array}{r}0 \\
10 \\
5 \\
3 \\
0\end{array}$ & $\begin{array}{r}0 \\
6 \\
12 \\
2 \\
0\end{array}$ & $\begin{array}{r}0 \\
21 \\
43 \\
5 \\
1\end{array}$ & $\begin{array}{r}3 \\
81 \\
183 \\
8 \\
4\end{array}$ & $\begin{array}{r}0 \\
35 \\
26 \\
21 \\
0\end{array}$ & $\begin{array}{r}0 \\
56 \\
69 \\
26 \\
1\end{array}$ & $\begin{array}{r}3 \\
137 \\
252 \\
34 \\
5\end{array}$ \\
\hline $\begin{array}{r}7 \\
8 \\
9 \\
10 \\
15\end{array}$ & $\begin{array}{r}30 \\
0 \\
1 \\
1 \\
0\end{array}$ & $\begin{array}{l}8 \\
1 \\
2 \\
2 \\
0\end{array}$ & $\begin{array}{l}8 \\
0 \\
1 \\
2 \\
0\end{array}$ & $\begin{array}{l}6 \\
1 \\
5 \\
6 \\
0\end{array}$ & $\begin{array}{r}10 \\
8 \\
90 \\
45 \\
3\end{array}$ & $\begin{array}{r}46 \\
1 \\
4 \\
5 \\
0\end{array}$ & $\begin{array}{r}52 \\
2 \\
9 \\
11 \\
0\end{array}$ & $\begin{array}{r}62 \\
10 \\
99 \\
56 \\
3\end{array}$ \\
\hline Subtotal & 76 & 31 & 31 & 88 & 435 & 138 & 226 & 661 \\
\hline \multicolumn{9}{|c|}{ Pahute Mesa } \\
\hline $\begin{array}{l}19 \\
20\end{array}$ & $\begin{array}{l}14 \\
20\end{array}$ & $\begin{array}{l}15 \\
22\end{array}$ & $\begin{array}{l}3 \\
3\end{array}$ & $\begin{array}{l}2 \\
1\end{array}$ & $\begin{array}{l}2 \\
3\end{array}$ & $\begin{array}{l}32 \\
45\end{array}$ & $\begin{array}{l}34 \\
46\end{array}$ & $\begin{array}{l}36 \\
49\end{array}$ \\
\hline Subtotal & 34 & 37 & 6 & 3 & 5 & 77 & 80 & 85 \\
\hline \multicolumn{9}{|c|}{ Rainier Mesa } \\
\hline 12 & 0 & 0 & 0 & 0 & 62 & 0 & 0 & 62 \\
\hline \multicolumn{9}{|c|}{ Frenchman Flat } \\
\hline $\begin{array}{r}5 \\
11 \\
\end{array}$ & $\begin{array}{l}1 \\
0\end{array}$ & $\begin{array}{l}2 \\
1\end{array}$ & $\begin{array}{l}1 \\
1\end{array}$ & $\begin{array}{l}1 \\
3\end{array}$ & $\begin{array}{l}0 \\
0\end{array}$ & $\begin{array}{l}4 \\
2\end{array}$ & $\begin{array}{l}5 \\
5\end{array}$ & $\begin{array}{l}5 \\
5\end{array}$ \\
\hline Subtotal & 1 & 3 & 2 & 4 & 0 & 6 & 10 & 10 \\
\hline \multicolumn{9}{|c|}{ Shoshone Mesa } \\
\hline 16 & 0 & 0 & 0 & 0 & 6 & 0 & 0 & 6 \\
\hline \multicolumn{9}{|c|}{ Buckboard Mesa } \\
\hline 18 & 0 & 0 & 0 & 0 & 3 & 0 & 0 & 3 \\
\hline \multicolumn{9}{|c|}{ Dome Mountain } \\
\hline 30 & 0 & 0 & 0 & 0 & 1 & $\mathbf{0}$ & 0 & 1 \\
\hline Total & 111 & 71 & 39 & 95 & 512 & 221 & 316 & 828 \\
\hline
\end{tabular}

${ }^{1}$ Zone includes region of widespread fracturing caused by detonation.

${ }^{2}$ Category defined as tests that certainly or probably have introduced test-generated contaminants directly into ground-water flow system; includes all tests detonated below water table and detonated above but within two cavity radii of water table.

${ }^{3}$ Category defined as the maximum number of tests (includes certain or probable category) likely to have introduced test-generated contaminants into ground-water flow system; includes all tests detonated below water table and detonated above but within five cavity radii of water table.

${ }^{4}$ Category includes all underground (and shallow cratering) tests. Number of tests is less than total number of detonations at Nevada Test Site because some tests include multiple detonations (U.S. Department of Energy, 1994). 
Tests at both locations have been detonated primarily in alluvium or in volcanic rocks. A few larger tests were detonated in the underlying carbonate rocks beneath northern Yucca Flat during early years of the testing program and three small tests were detonated in granite just north of Yucca Flat at the Climax stock (fig. 4; U.S. Department of Energy, 1994). As indicated in table 4, testing near or below the water table was fairly common in the Yucca Flat and Frenchman Flat test areas.

\section{Hydrogeologic Units}

The geologic settings of Yucca Flat and Frenchman Flat are discussed together in this section because they are similar and the hydrogeologic units in each are comparable. The eastern part of Yucca Flat basin (location of more than 90 percent of Yucca Flat underground nuclear tests) contains alluvium above a tuff, which in turn overlies carbonate rock (pls. 2 and 3). At Frenchman Flat, alluvium overlies a thinner sheet of volcanic rock that thins systematically eastward and southward (pls. 2 and 3); alluvium may directly overlie volcanic rock or carbonate rock along the southernmost and westernmost margins of the basin (pls. 2 and 3; Carr and others, 1975; Barnes and others, 1982).

The pre-Tertiary rocks in this region comprise the quartzite confining unit, the lower and upper carbonate-rock aquifers, and the Eleana confining unit (tables 1 and 2). Minor cylindrical intrusions of Cretaceous granite north of Yucca Flat are considered confining units on the basis of the low primary porosity and permeability. Miocene volcanic deposits that erupted from caldera sources to the west and northwest blanket the pre-Tertiary rocks, and are themselves covered by valley-fill alluvium within the fault-bounded troughs that typify the basins.

The quartzite confining unit crops out along the northeastern margins of Yucca Flat and farther north and east in the upgradient areas of Emigrant Valley and its surrounding ranges. It is inferred to significantly impede regional ground-water flow, in part, because its subsurface distribution coincides with a major change in the altitude of the water table-from about $4,500 \mathrm{ft}$ in Emigrant Valley to 2,400 ft at the north end of Yucca Flat (pl. 1; Winograd and Thordarson, 1975, p. 63-66). Lower Cambrian and Eocambrian quartzite, micaceous quartzite, and siliceous siltstone and shale make up most of the unit; thin and discontinuous limestone and dolomite beds occur in the upper and middle parts, but they do not appear to be significant hydrologic units. The estimated stratigraphic thickness of the quartzite confining unit is more than $10,000 \mathrm{ft}$ and for all practical purposes, it forms the hydrologic basement. The confining unit dips at moderate inclination (15 to 30 degrees) toward the west-southwest beneath the central part of the Yucca Flat basin as a result of tilting on the Carpetbag-Yucca fault system. Little is known of the physical and hydraulic characteristics of these rocks at depth, but results from a few wells suggest that brecciated fault zones may locally yield significant amounts of water (Harley Barnes, U.S. Geological Survey, written comm., 1962; Winograd and Thordarson, 1975, p. 41). Brittle quartzites tend to be intensely fractured relative to micaceous and shaley units, but outcrop observations indicate that fractures in quartzite are susceptible to resealing by silica and carbonate cement.

The lower carbonate-rock aquifer is a thick assemblage of interbedded dolomite and limestone that was deposited throughout the region between early Cambrian and late Middle Devonian time. The individual formations generally show fairly constant thickness and parallel contacts because deposition was continuous on the gently subsiding shelf of the North American continent. The aggregate stratigraphic thickness of carbonate rock is about $15,000 \mathrm{ft}$, although the effective thickness below the water table may be quite different at any given location due to thrust repetition or tilting, and to subsequent extensional faulting. The carbonate rocks generally dip west-southwest beneath the eastern side of Yucca Flat and are known from drilling to be continuous under the main areas of underground testing and south into Frenchman Flat. The zone at French Peak (pls. 2 and 3), which separates Yucca Flat and Frenchman Flat, is an important Tertiary structure that appears to have remained relatively stable, while the adjoining basins were widened and deepened during late Tertiary extension (Hudson, 1992). The top of the carbonate section projects above the water table and is inferred from gravity data to lie within $1,500 \mathrm{ft}$ of the surface in this area (pl. 2). Water levels within the lower carbonaterock aquifer exhibit little gradient (less than $1 \mathrm{ft} / \mathrm{mi}$ ) along the transect from northeastern Yucca Flat, through French Peak, through Frenchman Flat, and down to the discharge area at Ash Meadows (pls. 1 and 2). This flat gradient is an indication of a high degree of hydraulic continuity within the aquifer, and probably is a result of a high fracture permeability. 
The areal extent of the lower carbonate-rock aquifer, particularly within Yucca Flat, is not known in detail. The northeastern limit is clearly defined by the depositional contact with the underlying quartzite confining unit. The western limit of the aquifer appears to be a fault contact with the Eleana confining unit, although carbonate rocks that make up the lower carbonate-rock aquifer are expected at depth beneath the Eleana confining unit. The Tippinip fault at the extreme northern end of Yucca Flat (pl. 3) shows several thousand feet of stratigraphic offset and marks the surface trace of a major structural boundary that truncates the Eleana confining unit on the east. The continuation of this feature southward through the basin beneath the alluvium and volcanic rocks is highly uncertain. The distribution of Paleozoic formations interpreted from deep drill holes suggests that the pre-volcanic Tippinip fault may roughly coincide with the post-volcanic Carpetbag-Yucca fault system in northern Yucca Flat (pl. 3; Grow and others, 1994).

The Eleana confining unit coincides with the distribution of the late Devonian through late Mississippian Eleana Formation and the late Devonian through earliest Pennsylvanian Chainman Shale of NTS (Poole and others, 1961; Alan Titus, University of Nevada, written commun., 1991; for brevity, these rocks are referred to as Mississippian in age). The Eleana Formation consists of siliceous siltstone (argillite), chert-clast conglomerate and sandstone that are interpreted to have been deposited by submarine debris flows in a deep-water environment (Poole, 1974). A composite measured section along the west side of Yucca Flat indicates that the Eleana Formation could be as thick as 6,500 ft (Poole and others, 1961; Cole and others, 1994). More recent studies by Cashman and Trexler (1991 and 1994) and Cole and others (1994) provide biostratigraphic, sedimentologic, and structural evidence that the Eleana Formation has been thrust eastward over time-equivalent strata of the Chainman Shale, which may be more than $4,000 \mathrm{ft}$ thick.

Time-equivalent Mississippian strata near Mercury to the southeast are less than $1,300 \mathrm{ft}$ thick and consist of limestone and quartzose sand that were deposited on a stable carbonate bank (Poole, 1974; Barnes and others, 1982; Cole and others, 1994). Originally, the northwest part of the Eleana confining unit probably was a wedge-shaped deposit comprised of thick, deep-water siliciclastic units in the northwest; thick shale toward the southeast; and thin, carbonateplatform units along the margin of the continent.
The boundaries between these facies are not known in detail because they have been disturbed by faulting and because of cover by younger volcanic rocks (Cole and others, 1994).

Outcrop exposures and limited information from drilling indicate that the thickest part of the Eleana confining unit lies within a narrow arcuate band that extends from Quartzite Ridge (northwestern Yucca Flat area) southward to Mine Mountain and CP Hills, and then westward to Calico Hills and northern Bare Mountain (pls. 1 and 3; Monsen and others, 1990). In the Yucca Flat part of this band, outcrop of the Eleana Formation generally coincides with a high topographic divide of the Eleana Range and with the inferred westem boundary of the Ash Meadows subbasin.

The upper carbonate-rock aquifer is a heterogeneous mix of carbonate rocks that are separated hydraulically from the lower carbonate-rock aquifer by the Eleana confining unit (tables 1 and 2). Within the Ash Meadows subbasin, the aquifer is present only in western Yucca Flat. The aquifer is assumed to have limited regional significance. Rocks interpreted to form the upper carbonate-rock aquifer consist of two fundamentally different types: (1) limestone that stratigraphically overlies the Chainman Shale; and (2)

stratigraphically diverse carbonate rocks that structurally overlie the Eleana Formation and Chainman Shale.

The simplest part of this aquifer consists of Pennsylvanian limestone and conglomerate that crop out in western Yucca Flat in the core of a synclinal fold above the Chainman Shale (Hoover and Morrison, 1980; Cole and others, 1994). This limestone of the Tippipah limestone (Poole and others, 1961) is truncated to the north by post-volcanic faults, and probably is truncated southward by the Timber Mountain caldera. Due to its synclinal form, only a small part of the formation is saturated, and its hydrologic significance is considered minimal.

Elsewhere, the upper carbonate-rock aquifer refers to fractured dolomite or limestone that overlies the Eleana Formation or Chainman Shale on low-angle faults. Structural relations, apparent from outcrops at Mine Mountain near southwest Yucca Flat, indicate that large tabular masses of carbonate rock were emplaced westward and southwestward over the Eleana Formation by thrusting and later by regional extension sometime prior to the major period of volcanic activity (Cole and others, 1990). Rocks, particularly dolomite, within these blocks were intensely brecciated during sliding and later were recemented 
with calcite, silica, and iron oxides by circulating ground water. Similar outcrop relations in the CP Hills at the south end of Yucca Flat (Caskey, 1991), in the Calico Hills north of Jackass Flats (Simonds, 1989), and in the Eleana Range (Gibbons and others, 1963; Cashman and Trexler, 1991; J.C. Cole, U.S. Geological Survey, unpub. mapping, 1994; P. Cushman, University of Nevada, unpub. mapping, 1994) indicate that low-angle faults are present throughout the northwestem part of the Ash Meadows subbasin and that they bound detached blocks of Paleozoic carbonate rocks that lie above the Eleana confining unit.

Additional evidence strongly suggests that numerous dismembered blocks of dolomite or limestone lie above the Eleana confining unit at several locations beneath the Yucca Flat testing area. First, during investigations that followed the atmospheric release of radioactivity from the 1970 Baneberry test in northern Yucca Flat, four holes were drilled that penetrated alternating sections of brecciated dolomite and Chainman Shale beneath the Miocene volcanics (U.S. Geological Survey, 1974). Second, drill-hole information from the western and central parts of the basin (J.C. Cole, U.S. Geological Survey, unpub. data, 1994) shows several holes that bottomed in shale or siltstone (most likely part of the upper Chainman Shale) are surrounded by other holes that penetrated only preMississippian carbonate rocks, and depth relations strongly suggest that the carbonates lie structurally above the Chainman Shale. Third, paleontological results from limestone and dolomite recovered from scattered drill holes in Yucca Flat indicate that pre-Silurian rocks, which only crop out in a fairly undisturbed section in the Halfpint Range, east of Yucca Flat, are present in several drill holes across the basin (Grow and others, 1994). These spatial relations would seem to require some westward tectonic transport from the Halfpint Range to explain the distribution pattern.

Displaced blocks of pre-Mississippian carbonate rocks that make up the upper carbonate-rock aquifer are difficult to characterize hydrologically. Few data exist to determine whether these blocks are hydraulically connected or isolated from the lower carbonaterock aquifer, or to determine their permeability and porosity. The high degree of fracturing within these shattered carbonate rocks suggests that locally they may be highly permeable, and therefore may have local hydrologic significance.
The geologic and hydrologic data from ER-12-1 (J.C. Cole, U.S. Geological Survey, unpub. data, 1991; C.E. Russell, Desert Research Institute, written commun., 1994), a well drilled in 1991 on the east side of Rainier Mesa and west of the Eleana Range (pls. 2 and 3), further support the occurrence of displaced carbonate blocks. This hole penetrated, from the surface downward, lower Devonian dolomite, Ordovician limestone, Devonian dolomite, upper Mississippian Eleana Formation calcareous siltstone, upper Devonian dolomite, siliceous siltstone (most likely upper Mississippian Eleana Formation), and middle Devonian dolomite (A.G. Harris, U.S. Geological Survey, written commun., 1991). The carbonate rocks, therefore, are structurally and stratigraphically shuffled within themselves and with the Eleana Formation. The water levels in the dolomites below the Eleana Formation are more than $1,000 \mathrm{ft}$ lower than the levels in the carbonate rocks above the Eleana Formation (C.E. Russell, Desert Research Institute, written commun., 1992). This large difference suggests that, at least locally, the Eleana Formation is an effective vertical barrier (confining unit). Lateral continuity between the carbonate rocks beneath the Eleana Formation and the lower carbonate-rock aquifer beneath Yucca Flat is not known.

Granite stocks intruded during Cretaceous time are present in two areas, one north of Yucca Flat and the other north of Rainier Mesa (fig. 4, pl. 3). These rocks form small localized cylindrical bodies, which have a low primary porosity and permeability, and are grouped with rocks of the quartzite confining unit. Three small-yield nuclear tests were detonated within the stock directly north of Yucca Flat. Radioactive wastes, placed in engineered canisters, were stored for extended periods in this same stock within a subsurface tunnel complex (U.S. Department of Energy, 1990a), but were removed in the mid-1980's.

Tertiary volcanic rocks, where saturated, form both aquifers and confining units (pls. 2 and 3). The welded Rainier Mesa Tuff is widespread across the uppermost part of the section, and where it occurs below the water table forms the welded-tuff aquifer characterized by high fracture permeability. In southern Yucca Flat and northern Frenchman Flat, weldedtuff sheets of the Paintbrush Group are present below the Rainier Mesa Tuff and also form the welded-tuff aquifer. Most of the lower volcanic section in the Ash Meadows subbasin consists of bedded, nonwelded tuff that has been variably altered to zeolite minerals as a result of post-volcanic reactions with ground water. 
Because zeolitization decreases rock permeability, these altered zones form the tuff confining unit, and can include entire or parts of multiple stratigraphic units. The tuff confining unit is widespread throughout the entire Ash Meadows subbasin. The tuff confining unit and the volcanic aquifers have been offset thousands of feet by the Carpetbag-Yucca fault system, the Rock Valley-Cane Springs fault systems, and related smaller faults (pls. 2 and 3). These faults locally compartmentalize stratified hydrogeologic units into north-south blocks in Yucca Flat, for example, where welded-tuff aquifers are bounded on the east and west by fault contacts with the tuff confining unit. Plates 2 and 3 indicate that saturated volcanic rock is not continuous across the area separating Yucca Flat from Frenchman Flat, but, on the basis of alternate structural interpretations, its occurrence cannot be totally discarded.

The valley-fill aquifer coincides with the deepest parts of the post-volcanic fault-bounded depressions in southern Yucca Flat and central Frenchman Flat. The alluvium is variably cemented and consists of moderately sorted deposits of gravel and sand that show high interstitial porosity and permeability and transmit water efficiently. Playa lakebeds in both basins consist of siltstone and claystone deposits that are substantially less permeable than the coarser alluvium, but for the most part occur above the water table.

\section{Ground-Water Flow}

Most ground water flowing beneath the Yucca Flat and Frenchman Flat basins passes through the lower carbonate-rock aquifer (pls. 2 and 3, table 3). This aquifer is the only subsurface pathway by which ground water leaves either of these basins. As generalized from contours constructed from waterlevel measurements made in wells that penetrate the aquifer, ground water flows south from Yucca Flat into Frenchman Flat and then southwest toward the major downgradient discharge areas (primarily Ash Meadows, but possibly Alkali Flat or Death Valley (pls. 1 and 2). Flow of water into, through, and out of the lower carbonate-rock aquifer beneath these basins is controlled, in part, by (1) the occurrence of low permeability rocks both above and laterally adjacent to the aquifer, (2) lateral continuity with upgradient and downgradient sections of the lower carbonate-rock aquifer, (3) the occurrence of geologic structures (faults), and (4) secondary rock openings both within rocks of and rocks adjacent to the lower carbonate-rock aquifer (fractures, joints, and dissolution openings).

Much of the ground water flowing to Ash Meadows $(17,000$ acre-ft/yr according to Winograd and Thordarson, 1975, p. 84) passes beneath Frenchman Flat or beneath the area just south of Frenchman Flat (pl. 1), but originates primarily from outside these areas. More than 95 percent of the water passing beneath Frenchman Flat enters through the lower carbonate-rock aquifer from areas to the east and southeast (pls. 1 and 3). A small amount of inflow may also enter from the west across the Eleana confining unit and the underlying lower carbonate-rock aquifer (Winograd and Thordarson, 1975, p. 93-94). Flow into Frenchman Flat from Yucca Flat is small relative to inflows from the east and southeast and is estimated to be no greater than 350 acre-ft/yr (Winograd and Thordarson, 1975, p. 72)-less than 3 percent of the total outflow at the Ash Meadows discharge area.

Contributions from Yucca Flat are small because inflows to Yucca Flat are limited by confining units bounding the basin: (1) the quartzite confining unit on the northeast, (2) granitic rocks on the north, (3) the Eleana confining unit on the west, and (4) the tuff confining unit above. The low permeability of the rocks that laterally bound the lower carbonate-rock aquifer is evidenced by the steep hydraulic gradient across these units (pl. 1). Another potential source of water to Yucca Flat is inflow from the west through carbonate rock that underlies the Eleana confining unit at depth (pls. 2 and 3), but this source is likely to be small because rates of inflow are limited from above by the Eleana confining unit and from the west by lower permeability volcanic rocks. Conversely, it is also possible that some ground water from the lower-carbonate rock aquifer flows west-southwest into this block of carbonate rock that underlies the Eleana confining unit. The actual depth at which carbonate rock occurs below the Eleana confining unit and the degree of hydraulic continuity of the carbonate rock and the lower carbonate-rock aquifer in eastern Yucca Flat are yet to be determined. The total inflow to the lower carbonate-rock aquifer beneath eastern Yucca Flat from lateral sources is estimated by Winograd and Thordarson $(1975$, p. 94$)$ to be about 250 acre-ft/yr. Although this quantity is only a minor component of the total inflow to the aquifer within the Ash Meadows subbasin, it accounts for 
about 70 percent of the total inflow to the aquifer beneath Yucca Flat ( 350 acre- $\mathrm{ft} / \mathrm{yr}$ as calculated by Winograd and Thordarson, 1975, p. 94).

Recharge derived from sources within the basins provide only minor amounts of water to the flow system. Some surface runoff flowing into the valleys from nearby highlands may recharge the flow system along the margins of the valleys (Winograd and Thordarson, 1975, p. 92). During periods when open fissures are present in the dry bed of Yucca Lake, ponded surface runoff has been observed being drained by fissures and may be recharging the underlying lower carbonaterock aquifer (pl. 3). Doty and Rush (1984) measured 5 million cubic feet of inflow to such an open fissure over 3 years (1974-76); equivalent to about 39 acre$\mathrm{ft} / \mathrm{yr}$. A source of this magnitude would account for about 11 percent of the total annual estimated inflow to the lower carbonate-rock aquifer in eastern Yucca Flat. Subsequent to their report, the fissure has filled with sediment essentially sealing itself and no new fissures have been noted. Surface-water runoff and discharge from RNM-2S, a defunct pumping well used in a radionuclide migration experiment completed in 1991 (Bryant, 1992), drains into Frenchman Lake and may infiltrate downward possibly providing local recharge to underlying valley-fill aquifer (pls. 2 and 3; Burbey and Wheatcraft, 1986). Although these sources provide only minor amounts of recharge, they could carry contaminants present on the surface or contained within the unsaturated zone downward into the ground-water flow system, and in the Yucca Lake area, directly into the lower carbonate-rock aquifer.

Flow through the lower carbonate-rock aquifer is controlled largely by secondary openings in the rock, principally fractures. Fractures, which result from brittle deformation of the carbonate rock, increase the permeability of the rock unit such that they become the primary control on the rate and direction of groundwater flow. Fracture openings can be enhanced by dissolution of the surrounding carbonate rock. Although some solution caverns exist, primarily in the discharge areas, it is considered unlikely that they are common or extensive enough to be of major significance in the NTS region (Winograd and Thordarson, 1975, p. 115116). Little is known about the physical properties and hydraulic characteristics of fractures, primarily

because few wells penetrate saturated carbonate rock in the area (fewer than 10 wells penetrate more than 100 $\mathrm{ft}$ of saturated carbonate rock). Fractures undoubtedly are the primary control on ground-water flow within the lower carbonate-rock aquifer. Until fracture distributions (size, orientation, and density) are better characterized and fracture flow itself better understood, attempts to predict specific flow paths, flow rates, and contaminant transport within the lower carbonate-rock aquifer, especially on the local scale, are subject to much uncertainty.

Although the lower carbonate-rock aquifer is described as a single water-bearing unit (table 1), it actually consists of multiple, stratigraphically and structurally compartmented rocks. Thin, regionally persistent units ( 50 to $200 \mathrm{ft}$ thick) of shale, quartzite, or siltstone are present at several stratigraphic positions within the carbonate section. These noncarbonate rocks are much less permeable than the more extensive, highly fractured carbonate strata and are likely to create stratified, semi-independent flow systems within the lower carbonate-rock aquifer. As previously stated, few wells penetrate a significant thickness of saturated carbonate rock, and therefore, it is difficult to evaluate the extent or significance of these more localized flow systems or to determine the overall effect that these rocks may have on the transport of test-generated contaminants.

Faults also influence the flow of ground water through the lower carbonate-rock aquifer, and are presumed to act either as barriers or conduits depending on the nature of fault-generated openings and on the hydraulic properties of the units brought into contact. In western Yucca Flat, the Carpetbag and Tippinip faults locally juxtapose the Eleana confining unit against the lower carbonate-rock aquifer (pl. 3). The large permeability contrast between these units is thought to create an effective barrier to lateral flow. Some water leaving Frenchman Flat may flow more rapidly along preferred pathways in the lower carbonate-rock aquifer according to Winograd and Pearson (1976). They refer to these transmissive pathways as "megachannels" and propose their existence to explain differences in the carbon-14 content of water issuing from springs at Ash Meadows. Their hypothesis requires zones of high permeability that may result from intense fracturing associated with faulting along major fault systems, such as the Rock Valley system (pl. 2). Megachanneling would significantly affect flow rates and directions in the lower carbonate-rock aquifer, and would result in higher concentrations and faster traveltimes than would be predicted in a nonchanneled flow system. If potential transport paths and rates are to be predicted at some quantifiable level within the lower 
carbonate-rock aquifer, it must be determined how major faults influence the flow of ground water and transport of contaminants, not only within the Yucca Flat and Frenchman Flat test areas, but also in the region between these test areas and Ash Meadows.

Few attempts have been made to quantify flow rates through the lower carbonate-rock aquifer in the Yucca Flat and Frenchman Flat areas. Most estimates are based on water-transmitting properties calculated by methods that assume flow through porous rather than fractured media. Winograd and Thordarson (1975, table 15) give estimates as ranges between 6 and 600 $\mathrm{ft} / \mathrm{yr}$ for Yucca Flat, and between 600 to $60,000 \mathrm{ft} / \mathrm{yr}$ for the area between Frenchman Flat and Ash Meadows. The large ranges reflect both spatial variation and a high degree of uncertainty in the controlling properties, particularly the effective fracture porosity.

As stated previously, most of the water enters the lower carbonate-rock aquifer beneath Yucca Flat and Frenchman Flat laterally, but some also enters locally as leakage through overlying saturated unitsthe valley-fill and welded-tuff aquifers and the tuff confining unit. Winograd and Thordarson (1975, p. 53-57) infer from vertical hydraulic gradients that ground water within the saturated units overlying the lower carbonate-rock aquifer generally flows laterally toward the center of the basins and downward into the lower carbonate-rock aquifer. They further support downward leakage into the lower carbonate-rock aquifer on the basis of sodium and sulfate concentrations. Concentrations of these ions in water sampled from the lower carbonate-rock aquifers beneath and downgradient of valleys containing saturated volcanic or valleyfill deposits typically are higher than would be expected for water derived solely from carbonate rock. The source for these ions is assumed to be water originating or passing through overlying valley-fill alluvium or volcanic rocks.

The rate at which water leaks downward from the Cenozoic rocks into the lower carbonate-rock aquifer varies throughout the valleys and is controlled primarily by the vertical permeability (measure of the potential of a rock to transmit water vertically) of the overlying unit(s). The tuff confining unit, a low permeability unit, directly overlies most of the lower carbonate-rock aquifer in Yucca Flat. The extent of the tuff confining unit throughout Frenchman Flat is less well known. It should be noted that the tuff confining unit consists of multiple stratigraphic units (table 1), some of which are more permeable than others. In the southern part of Frenchman Flat, the lower carbonaterock aquifer is overlain by alluvium, a more permeable material, but whether alluvium is saturated at this location is unknown.

High-angle faults that cut the overlying saturated units also affect the rate at which water recharges the lower carbonate-rock aquifer. The Yucca-Carpetbag fault system passes north-south through the center of Yucca Flat (pl. 3), and may form vertical conduits for flow between the lower carbonate-rock aquifer and overlying saturated units according to Winograd and Thordarson (1975, p. 55). Their conclusion is based on lower water levels in the overlying units generally centered about the Yucca fault in central Yucca Flat (pl. 3). They suggest that the hydraulic low may be due to drainage into the underlying lower carbonate-rock aquifer and give two potential mechanisms for faultcontrolled recharge: (1) that the brecciated and fractured zones created by faulting serves as a permeable pathway for ground-water flow, and (2) that faults may juxtapose the welded-tuff aquifer (a permeable unit) against the lower carbonate-rock aquifer creating a more permeable pathway than that typical of the tuff confining unit. Assuming that water first passes through the tuff confining unit before recharging the lower carbonate-rock aquifer, Winograd and Thordarson $(1975$, p. 94) estimated the probable range of annual downward recharge into Yucca Flat to be 25 to 65 acre-ft using median measured values of interstitial permeability for the tuff confining unit, and a typical range of hydraulic gradients calculated from measured water levels in the lower carbonate-rock aquifer and saturated Cenozoic rocks. A similar magnitude of recharge was assumed for Frenchman Flat.

Few quantitative estimates of leakage rates into the lower carbonate-rock aquifer are available. Leakage rates through the tuff confining unit were estimated between 0.0005 to $0.2 \mathrm{ft} / \mathrm{yr}$ by Winograd and Thordarson (1975, table 14). These estimates span the expected range of rates through the tuff confining unit and assume that water moves only through the primary interstices. Estimates do not take into account potential increases in permeability associated with fractures, nor the higher permeability of volcanic and valley-fill aquifers at locations where they are in contact with the lower carbonate-rock aquifer. Most underground tests in these valleys were detonated in the alluvium and volcanic rocks that overlie the lower carbonate-rock aquifer. Leakage is the primary mechanism by which 
test-generated byproducts would move downward through these units into the lower carbonate-rock aquifer, yet the controlling parameters are poorly defined.

The only natural ground-water discharge local to the basins is from a few perched springs along the margins of the valleys at altitudes well above the valley floor (pl. 3). Springflow is sustained primarily by local precipitation falling on nearby highlands. Downward percolating recharge is diverted to the surface by lowpermeability rocks. Because this water never reaches the regional flow system, it is highly unlikely that any springflow would be contaminated by underground testing in Yucca Flat or Frenchman Flat.

Wells presently withdraw water from several locations throughout the valleys (pl. 3). Withdrawal during 1991 totaled about 990 acre-ft. The total includes pumpage from well RNM-2S, a well in Frenchman Flat drilled for a radionuclide migration experiment discontinued in August 1991 (Bryant, 1992). Of this total, about 240 acre-ft were produced from wells in the Yucca Flat area (D.B. Wood, U.S. Geological Survey, written commun., 1991). A withdrawal of this magnitude equates to about 70 percent of the total estimated inflow into Yucca Flat basin or nearly all the total estimated inflow from lateral sources. During 1991, RNM-2S yielded nearly 60 percent of all water withdrawn from the Frenchman Flat area (which includes withdrawals from Water Well 4 located just northwest of Frenchman Flat in CP Basin). Water Well C and Water Well C1 are the only wells producing from the lower carbonate-rock aquifer at points downgradient of underground testing in Yucca Flat. Together these wells yielded about 65 percent of all water withdrawn from the Yucca Flat area during 1991 and about 63 percent of the total annual estimated inflow to the lower carbonate-rock aquifer beneath eastern Yucca Flat. The effect of withdrawals on ground-water flow have not been thoroughly investigated, but on the basis of the percentages given in relation to estimated inflows, it is apparent that they would have a significant affect on the water budget as determined by Winograd and Thordarson (1975, p. 62-94). Assessing the changes in hydrologic conditions that have resulted from withdrawing ground water would provide an opportunity to learn about the water transmitting and storing properties, and the transport properties of the ground-water flow system.

Radionuclide concentrations measured in water produced from active and abandoned water-supply wells have never exceeded standards for human consumption. Claassen (1973, p. 134-135) noted an increase in alpha activities at Water Well C, Water Well $\mathrm{C} 1$, Water Well 2, and a few other abandoned production wells during sampling in the late 1960's and early 1970's. The increased alpha activity observed in Water Wells $\mathrm{C}$ and $\mathrm{C1}$ between 1969 and 1971 (Claassen, 1973, p. 62-77) has since declined to near background levels (U.S. Environmental Protection Agency, 1991). The cause of the increases has not been determined. Possible explanations include residual effects of a radioactive tracer introduced into Water Well C1 in 1960 , the movement of contaminants from test areas upgradient in Yucca Flat, or downward migration through open cracks in the nearby dry lake bed at Yucca Lake. Lyles (1993, p. 2-7) noted gradual increases in tritium concentrations in Water Well $A$ and UE-15d from samples collected primarily during the period when these wells were pumped for water supply. Lyles attributed the increases at Water Well $\mathrm{A}$ to movement from test locations upgradient of the well. The source of the tritium in UE-15d is not known, but possible sources given by Lyles (1993, p. 2) are tests detonated in granite to the north or downward movement of contaminated water from evaporation ponds near the well. Increased radionuclide concentrations also were observed at RNM-2S (Bryant, 1992), but here, increases were expected because the well was located and pumped to induce radionuclide movement from the nearby Cambric test location. The reader is referred to Bryant (1992) for a more complete discussion of the findings related to this experiment.

The preceding discussion provides a general description of ground-water flow beneath the Yucca Flat and Frenchman Flat test areas. The conceptual model presented identifies the lower carbonate-rock aquifer as the principal pathway by which radionuclides could leave Yucca Flat and Frenchman Flat and migrate into a more accessible environment. Based on this model, any assessment of the risk associated with underground testing in Yucca Flat and Frenchman Flat requires a knowledge of how test-generated contaminants introduced into alluvium and volcanic rocks can migrate downward into the lower carbonate-rock aquifer, and an understanding of how test-generated contaminants would be transported through the lower carbonate-rock aquifer. These critical questions can only be resolved through concentrated efforts directed at developing a better understanding of the controls, such as fractures, on ground-water flow into and through the lower-carbonate-rock aquifer. 
Table 5. Water levels, underground tests, and associated test and hole parameters used to determine general position of test relative to the water table

[All depths referenced to land-surface datum. Altitude relative to sea level. Working point is depth at which nuclear device is detonated. Dashes indicate missing or non applicable parameter. Sources are U.S. Department of Energy (1994) and classified listing of test parameters (Lawrence Livermore National Laboratory, written commun., 1991, 1992)]

\begin{tabular}{|c|c|c|c|c|c|c|c|}
\hline \multirow[b]{2}{*}{ Hole name } & \multirow[b]{2}{*}{ Test name } & \multirow[b]{2}{*}{$\begin{array}{c}\text { Altitude } \\
\text { (feet) }\end{array}$} & \multicolumn{2}{|c|}{ Depth of } & \multirow{2}{*}{$\begin{array}{l}\text { Distance of } \\
\text { test from } \\
\text { water } \\
\text { (feet) }\end{array}$} & \multirow[b]{2}{*}{$\begin{array}{c}\text { Date of } \\
\text { test }\end{array}$} & \multirow[b]{2}{*}{$\begin{array}{c}\text { Yield of } \\
\text { test } \\
\text { (kilotons) }\end{array}$} \\
\hline & & & $\begin{array}{l}\text { Working } \\
\text { point } \\
\text { (feet) }\end{array}$ & $\begin{array}{l}\text { Water } \\
\text { (feet) }\end{array}$ & & & \\
\hline UE-18r & - & 5,538 & -- & 1,365 & - & -- & - \\
\hline UE-18t & -- & 5,201 & -- & 916 & - & - & -- \\
\hline Water Well 8 & -- & 5,695 & -- & 1,076 & - & - & -- \\
\hline U-19aa & Sheepshead & 6,758 & 2,100 & 2,326 & 226 & $79-09-26$ & $20-150$ \\
\hline U-19ab & Towanda & 6,928 & 2,182 & 2,024 & -158 & $85-05-02$ & $20-150$ \\
\hline U-19ab 2/Inst. & -- & 6,930 & -- & 2,015 & -- & -- & - \\
\hline U-19ac & Tierra & 7,038 & 2,100 & 2,284 & 184 & $84-12-15$ & $20-150$ \\
\hline U-19ad & Chancellor & 6,692 & 2,051 & 2,123 & 72 & $83-09-01$ & 143 \\
\hline U-19ae & Nebbiolo & 6,775 & 2,100 & 2,280 & 180 & $82-06-24$ & $20-150$ \\
\hline U-19af & Galveston & 6,710 & 1,598 & 2,280 & 682 & $86-09-04$ & $>20$ \\
\hline U-19ai & Serpa & 6,742 & 1,880 & 2,054 & 174 & $80-12-17$ & $20-150$ \\
\hline U-19aj & Harzer & 6,891 & 2,090 & 2,192 & 102 & $81-06-06$ & $20-150$ \\
\hline U-19ak & Hosta & 6,898 & 2,100 & 2,192 & 92 & $82-02-12$ & $20-150$ \\
\hline U-19am & -- & 6,710 & -- & 2,060 & -- & -- & -- \\
\hline U-19an & Labquark & 6,978 & 2,021 & 2,103 & 82 & $86-09-30$ & $20-150$ \\
\hline U-19aq & Lockney & 6,798 & 2,018 & 2,109 & 91 & $87-09-24$ & $20-150$ \\
\hline U-19ar & Cybar & 6,706 & 2,057 & 2,119 & 62 & $86-07-17$ & 119 \\
\hline U-19aS & Scotch & 6,761 & 3,206 & 2,192 & $-1,014$ & $67-05-23$ & 155 \\
\hline U-19au & Alamo & 6,535 & 2,038 & 2,077 & 39 & $88-07-07$ & $<150$ \\
\hline U-19av & -- & 6,512 & -- & 2,022 & -- & -- & - \\
\hline U-19ax & Kearsarge & 6,986 & 2,018 & 2,297 & 279 & $88-08-17$ & $<150$ \\
\hline U-19ay & Amarillo & 6,713 & 2,100 & 2,129 & 29 & $89-06-27$ & $20-150$ \\
\hline U-19az & Houston & 6,753 & 1,949 & 2,079 & 130 & $90-11-14$ & $20-150$ \\
\hline U-19b & Halfbeak & 6,791 & 2,687 & 2,116 & -571 & $66-06-30$ & 365 \\
\hline U-19b 1 & -- & 6,802 & -- & 2,117 & -- & -- & -- \\
\hline $\mathrm{U}-19 \mathrm{ba}$ & Bexar & 7,037 & 2,064 & 2,152 & 88 & $91-04-04$ & $20-150$ \\
\hline U-19bg & Junction & 6,691 & 2,041 & 2,115 & 74 & 92-03-06 & $20-150$ \\
\hline U-19bg 1 & -- & 6,694 & -- & 2,119 & -- & -- & -- \\
\hline$U-19 c$ & Rickey & 7,032 & 2,241 & 2,320 & 79 & $68-06-15$ & $20-200$ \\
\hline UE-19c Water Well & -- & 7,033 & -- & 2,336 & -- & -- & -- \\
\hline U-19d & Chartreuse & 6,861 & 2,185 & 2,172 & -13 & $66-05-06$ & 73 \\
\hline U-19d 2 & -- & 6,861 & -. & 2,177 & - & -- & -- \\
\hline U-19e & Muenster & 6,920 & 4,764 & 2,222 & $-2,542$ & $76-01-03$ & $200-1,000$ \\
\hline U-19e/Inst. & -- & 6,919 & -- & 2,217 & -- & -- & -- \\
\hline $\mathrm{U}-19 \mathrm{f}$ & Inlet & 6,734 & 2,687 & 2,307 & -380 & $75-11-20$ & $200-1,000$ \\
\hline U-19fS & -- & 6,735 & - & 2,306 & - & -- & -- \\
\hline $\mathrm{U}-19 \mathrm{~g}$ & Estuary & 6,734 & 2,848 & 2,064 & -784 & $76-03-09$ & $200-500$ \\
\hline U-19gS & - & 6,719 & -- & 2,045 & - & -- & -- \\
\hline UE-19h & -- & 6,780 & - & 2,112 & -- & -- & -- \\
\hline $\mathrm{U}-19 \mathrm{i}$ & Sled & 6,836 & 2,389 & 2,192 & -197 & $68-08-29$ & $20-200$ \\
\hline UE-19i & - & 6,839 & -- & 2,258 & -- & -- & -- \\
\hline U-19L & Stinger & 6,766 & 2,188 & 2,100 & -88 & $68-03-22$ & $20-200$ \\
\hline $\mathrm{U}-19 \mathrm{n}$ & Scroll & 6,754 & 735 & 2,083 & 1,348 & $68-04-23$ & $<20$ \\
\hline$U-19 p$ & Pool & 6,899 & 2,884 & 2,264 & -620 & $76-03-17$ & $200-500$ \\
\hline U-19q & Camembert & 6,758 & 4,298 & 2,192 & $-2,106$ & $75-06-26$ & $200-1,000$ \\
\hline
\end{tabular}


Table 5. Water levels, underground tests, and associated test and hole parameters used to determine general position of test relative to the water table-Continued

\begin{tabular}{|c|c|c|c|c|c|c|c|}
\hline \multirow[b]{2}{*}{ Hole name } & \multirow[b]{2}{*}{ Test name } & \multirow[b]{2}{*}{$\begin{array}{c}\text { Altitude } \\
\text { (feet) }\end{array}$} & \multicolumn{2}{|c|}{ Depth of } & \multirow{2}{*}{$\begin{array}{l}\text { Distance of } \\
\text { test from } \\
\text { water } \\
\text { (feet) }\end{array}$} & \multirow[b]{2}{*}{$\begin{array}{c}\text { Date of } \\
\text { test }\end{array}$} & \multirow[b]{2}{*}{$\begin{array}{c}\text { Yield of } \\
\text { test } \\
\text { (kilotons) }\end{array}$} \\
\hline & & & $\begin{array}{l}\text { Working } \\
\text { point } \\
\text { (feet) }\end{array}$ & $\begin{array}{l}\text { Water } \\
\text { (feet) }^{1}\end{array}$ & & & \\
\hline $\mathrm{U}-19 \mathrm{t}$ & Emmenthal & 6,991 & 1,890 & 2,231 & 341 & $78-11-02$ & $<20$ \\
\hline $\mathrm{U}-19 \mathrm{u}$ & Mast & 6,873 & 2,989 & 2,185 & -804 & $75-06-19$ & $200-1,000$ \\
\hline$U-19 v$ & Almendro & 6,876 & 3,488 & 2,251 & $-1,237$ & $73-06-06$ & $200-1,000$ \\
\hline UE-19v PS 1D & -- & 6,842 & - & 2,297 & -- & - & $\cdots$ \\
\hline UE-19w 1 & -- & -- & -- & 2,450 & -- & -- & -- \\
\hline$U-19 x$ & Backbeach & 6,781 & 2,205 & 2,214 & 9 & $78-04-11$ & $20-150$ \\
\hline U-19yS & Panir & 6,694 & 2,234 & 2,116 & -118 & $78-08-31$ & $20-150$ \\
\hline$U-19 z S$ & Fondutta & 6,888 & 2,077 & 2,192 & 115 & $78-04-11$ & $20-150$ \\
\hline U-19zS/Inst. & -- & 6,888 & -- & 2,199 & -- & -- & -- \\
\hline Pahute Mesa Ex. 1 & -- & 6,558 & -- & 2,099 & - & - & - \\
\hline Pahute Mesa Ex. 2 & -- & 5,586 & -- & 852 & -- & - & -- \\
\hline Pahute Mesa Ex. 3 & -- & 5,823 & -- & 1,457 & -- & -- & -- \\
\hline U-20a & Buteo & 6,520 & 2,284 & 2,159 & -125 & $65-05-12$ & $<20$ \\
\hline U-20 Water Well & - & 6,468 & -- & 2,028 & -- & -- & -- \\
\hline U-20a-1 & Duryea & 6,520 & 1,785 & 2,172 & 387 & $66-04-14$ & 70 \\
\hline U-20a-2 Water Well & -- & 6,474 & -- & 2,066 & -- & -- & -- \\
\hline $\mathrm{U}-20 \mathrm{aa}$ & Colby & 6,337 & 4,177 & 1,874 & $-2,303$ & $76-03-14$ & $500-1,000$ \\
\hline $\mathrm{U}-20 \mathrm{ab}$ & Farm & 6,581 & 2,261 & 2,116 & -145 & $78-12-16$ & $20-150$ \\
\hline $\mathrm{U}-20 \mathrm{ac}$ & Colwick & 6,473 & 2,077 & 2,067 & -10 & $80-04-26$ & $20-150$ \\
\hline U-20ad & Pepato & 6,366 & 2,234 & 1,900 & -334 & $79-06-11$ & $20-150$ \\
\hline $\mathrm{U}-20 \mathrm{ae}$ & Tafi & 6,189 & 2,231 & $l, 992$ & -239 & $80-07-25$ & $20-150$ \\
\hline U-20af & Kash & 6,360 & 2,116 & 1,975 & -141 & $80-06-12$ & $20-150$ \\
\hline U-20ag & Molbo & 6,234 & 2,093 & 2,015 & -78 & $82-02-12$ & $20-150$ \\
\hline $\mathrm{U}-20 \mathrm{ah}$ & Gibne & 6,445 & 1,870 & 2,001 & 131 & $82-04-25$ & $20-150$ \\
\hline U-20ai & Jefferson & 6,503 & 1,998 & 2,052 & 54 & $86-04-22$ & $20-150$ \\
\hline U-20aj & Cabra & 6,345 & 1,778 & 1,874 & 96 & $83-03-26$ & $20-150$ \\
\hline U-20ak & Salut & 6,235 & 1,995 & 2,042 & 47 & $85-06-12$ & $20-150$ \\
\hline U-20aL & Egmont & 6,124 & 1,791 & 1,936 & 145 & $84-12-09$ & $20-150$ \\
\hline U-20am & Kappeli & 6,593 & 2,100 & 2,142 & 42 & $84-07-25$ & $20-150$ \\
\hline U-20an & Serena & 6,462 & 1,959 & 1,991 & 32 & $85-07-25$ & $20-150$ \\
\hline U-20ao & Goldstone & 6,279 & 1,801 & 1,957 & 156 & $85-12-28$ & $20-150$ \\
\hline U-20ap & Bodie & 6,621 & 2,083 & 2,139 & 56 & $86-12-13$ & $20-150$ \\
\hline $\mathrm{U}-20 \mathrm{aq}$ & Darwin & 6,155 & 1,801 & 1,883 & 82 & $86-06-25$ & $20-150$ \\
\hline U-20ar & Kernville & 6,319 & 1,775 & 1,841 & 66 & $88-02-15$ & $20-150^{\circ}$ \\
\hline U-20ar 1/Inst. & - & 6,319 & - & 1,841 & - & -- & - \\
\hline $\mathrm{U}-20$ as & Belmont & 6,227 & 1,985 & 2,013 & 28 & $86-10-16$ & $20-150$ \\
\hline U-20at & Delamar & 6,240 & 1,785 & 1,903 & 118 & $87-04-18$ & $20-150$ \\
\hline U-20at 1/Inst. & -- & 6,241 & -- & 2,027 & - & - & - \\
\hline U-20av & Hardin & 6,464 & 2,051 & 2,075 & 24 & $87-04-30$ & $20-150$ \\
\hline UE-20av & - & 6,458 & & 2,128 & -- & -- & -- \\
\hline U-20aw & Contact & 6,585 & 1,785 & 2,086 & 301 & $89-06-22$ & $20-150$ \\
\hline U-20ax & -- & 6,535 & $\ldots$ & 2,173 & -- & -- & -- \\
\hline U-20ay & Comstock & 6,520 & 2,034 & 2,055 & 21 & $88-06-02$ & $<150$ \\
\hline $\mathrm{U}-20 \mathrm{az}$ & Barnwell & 6,572 & 1,969 & 2,160 & 191 & $89-12-08$ & $20-150$ \\
\hline $\mathrm{U}-20 \mathrm{~b}$ & Pipkin & 6,534 & 2,047 & 2,100 & 53 & $69-10-08$ & $200-1,000$ \\
\hline
\end{tabular}


Table 5. Water levels, underground tests, and associated test and hole parameters used to determine general position of test relative to the water table-Continued

\begin{tabular}{|c|c|c|c|c|c|c|c|}
\hline \multirow[b]{2}{*}{ Hole name } & \multirow[b]{2}{*}{ Test name } & \multirow[b]{2}{*}{$\begin{array}{c}\text { Altitude } \\
\text { (feet) }\end{array}$} & \multicolumn{2}{|c|}{ Depth of } & \multirow{2}{*}{$\begin{array}{l}\text { Distance of } \\
\text { test from } \\
\text { water } \\
\text { (feet) }\end{array}$} & \multirow[b]{2}{*}{$\begin{array}{c}\text { Date of } \\
\text { test }\end{array}$} & \multirow[b]{2}{*}{$\begin{array}{c}\text { Yield of } \\
\text { test } \\
\text { (kilotons) }\end{array}$} \\
\hline & & & $\begin{array}{l}\text { Working } \\
\text { point } \\
\text { (feet) }\end{array}$ & $\begin{array}{l}\text { Water } \\
\text { (feet) }^{1}\end{array}$ & & & \\
\hline $\mathrm{U}-20 \mathrm{bb}$ & Tenabo & 6,226 & 1,969 & 2,028 & 59 & $90-10-12$ & $20-150$ \\
\hline U-20bb 1 & - & 6,230 & -- & 2,028 & - & -- & -- \\
\hline $\mathrm{U}-20 \mathrm{bc}$ & Hornitos & 6,146 & 1,847 & 1,871 & 24 & $89-10-31$ & $20-150$ \\
\hline U-20bd & Bullion & 6,486 & 2,225 & 2,038 & -187 & $90-06-13$ & $20-150$ \\
\hline $\mathrm{U}-20 \mathrm{be}$ & Hoya & 6,493 & 2,159 & 2,215 & 56 & $91-09-14$ & $20-150$ \\
\hline $\mathrm{U}-20 \mathrm{bf}$ & Montello & 6,522 & 2,106 & 2,086 & -20 & $91-04-16$ & $20-150$ \\
\hline U-20bg & - & 6,567 & -- & 2,129 & -- & -- & -. \\
\hline $\mathrm{U}-20 \mathrm{c}$ & Benham & 6,281 & 4,600 & 2,097 & $-2,503$ & $68-12-19$ & 1,150 \\
\hline UE-20c & -- & 6,283 & -- & 2,126 & -- & -- & -- \\
\hline $\mathrm{U}-20 \mathrm{~d}$ & Knickerbocker & 6,252 & 2,067 & 2,075 & 8 & $67-05-26$ & 76 \\
\hline UE-20d & - & 6,253 & -- & 2,075 & -- & -- & -- \\
\hline $\mathrm{U}-20 \mathrm{e}$ & Jorum & 6,316 & 3,809 & 1,853 & $-1,956$ & $69-09-16$ & $<1,000$ \\
\hline UE-20e 1 & -- & 6,297 & -- & 1,826 & - & -- & -- \\
\hline U-20f & Fontina & 6,117 & 4,000 & 1,952 & $-2,048$ & $76-02-12$ & $200-1,000$ \\
\hline UE-20f & - & 6,116 & -- & 1,954 & - & -- & -- \\
\hline $\mathrm{U}-20 \mathrm{~g}$ & Greeley & 6,470 & 3,990 & 2,017 & $-1,973$ & $66-12-20$ & 870 \\
\hline $\mathrm{UE}-20 \mathrm{~h}$ & $\operatorname{Rex}$ & 6,557 & 2,202 & 2,105 & -97 & $66-02-24$ & 19 \\
\hline $\mathrm{U}-20 \mathrm{i}$ & Boxcar & 6,370 & 3,822 & 1,903 & $-1,919$ & $68-04-26$ & 1,300 \\
\hline $\mathrm{U}-20 \mathrm{k}$ & Palanquin & 6,194 & 279 & 1,993 & 1,714 & $65-04-14$ & 4.3 \\
\hline U-20L & Cabriolet & 6,197 & 167 & 1,997 & 1,830 & $68-01-26$ & 2.3 \\
\hline $\mathrm{U}-20 \mathrm{~m}$ & Handley & 5,903 & 3,967 & 1,270 & $-2,697$ & $70-03-26$ & $>1,000$ \\
\hline U-20n & Cheshire & 6,477 & 3,829 & 2,051 & $-1,778$ & $76-02-14$ & $200-500$ \\
\hline UE-20n 1 & - & 6,461 & - & 2,134 & -- & - & -- \\
\hline$U-20 p$ & Stilton & 5,559 & 2,402 & 884 & $-1,518$ & $75-06-03$ & $20-200$ \\
\hline UE-20p & - & 5,553 & -- & 884 & -- & -- & - \\
\hline $\mathrm{U}-20 \mathrm{t}$ & Chateaugay & 6,245 & 1,992 & 2,074 & 82 & $68-06-28$ & $20-200$ \\
\hline $\mathrm{U}-20 \mathrm{u}$ & Schooner & 5,562 & 364 & 899 & 535 & $68-12-08$ & 30 \\
\hline$U-20 v$ & Purse & 6,088 & 1,962 & 1,972 & 10 & $69-05-07$ & $20-200$ \\
\hline $\mathrm{U}-20 \mathrm{y}$ & Tybo & 6,257 & 2,510 & 2,067 & -443 & $75-05-14$ & $200-1,000$ \\
\hline $\mathrm{U}-20 \mathrm{z}$ & Kasseri & 6,509 & 4,151 & 2,061 & $-2,090$ & $75-10-28$ & $200-1,000$ \\
\hline
\end{tabular}

\footnotetext{
${ }^{1}$ Italicized values are estimated. Non-italicized values are measured. Estimates based on measurements in nearby wells and test holes or interpreted from water-level contours given in Blankennagel and Weir (1973, pl. 1).
}

\section{Pahute Mesa and Rainier Mesa}

The Pahute Mesa and Rainier Mesa underground test areas are in the northwestern part of NTS (figs. 1 and 2). These areas provided locations for 147 tests (U.S. Department of Energy, 1994), of which 85 were on Pahute Mesa and 62 on Rainier Mesa (tables 4 and 5). All underground tests within these areas were detonated in volcanic rock.
Pahute Mesa, an elevated plateau, ranges in altitude from about $5,500 \mathrm{ft}$ along its western margin to more than $7,000 \mathrm{ft}$ throughout its eastern extent. Testing has been confined to the eastern part of the mesa within NTS Areas 19 and 20 (pl. 4). The test area includes upgradient parts of the Oasis Valley and Alkali Flat-Furnace Creek Ranch ground-water subbasins (table 3, pl. I). Most tests on Pahute Mesa were detonated near or below the water table (tables 4 and 5) in deep shafts drilled into volcanic rock. Of the 85 tests 
on Pahute Mesa, at least 77 and as many as 80 were detonated at depths sufficient to have introduced contaminants directly into the ground-water flow system.

Rainier Mesa, an extension of Pahute Mesa toward the southeast, is about $7,600 \mathrm{ft}$ above sea level. The test area lies along the poorly defined hydrologic divide between the Alkali Flat-Furnace Creek Ranch and the Ash Meadows subbasins (table 3, pl. 1). The 62 tests in Rainier Mesa were detonated in tuff within mined tunnels. Although all tests were detonated above the regional water table (table 4), it should be noted that perched water is a common occurrence throughout the mesa.

\section{Hydrogeologic Units}

Pahute Mesa and Rainier Mesa are parts of the southwest Nevada volcanic field (fig. 4), and consist chiefly of Miocene rhyolitic volcanic rocks that erupted from local calderas (fig. 5). The volcanic rocks, depending primarily on the lithology, degree of fracturing, secondary mineralization, and mineral alteration, act either as aquifers or confining units. Lava flows generally form aquifers because they contain numerous connected fractures. Partially to densely welded ashflow tuffs also form aquifers that are characterized by high fracture permeability, and if unaltered, by moderately high interstitial permeability (Blankennagel and Weir, 1973, p. 6-8). Nonwelded ash-flow tuffs and bedded ash-fall tuffs are more susceptible than welded tuffs and lavas to zeolitic alteration, which usually results in decreased rock permeability. Therefore, nonwelded ash-fall tuffs generally form confining units characterized by low permeability and relatively disconnected fractures. Individual stratigraphic units commonly act as aquifers in some areas and as confining units in others due to spatial variations in lithology and mineral alteration. These volcanic units in Pahute Mesa and Rainier Mesa make up a complex, threedimensional framework of lava-flow and welded-tuff aquifers interbedded with nonwelded tuff confining units, all of which are offset by high-angle normal faults (table 1, pl. 4).

The southwest Nevada volcanic field was the source of numerous major eruptions of rhyolitic magma during its 6 to 8 million year history. In a simple conceptual model, each major ash-flow eruption (generally more than $50 \mathrm{mi}^{3}$ ) is accompanied by the subsidence of a cylindrical block in the caldera center. The resulting caldera structure is given the same name as the corresponding ash-flow deposit (for example, the eruption of the Grouse Canyon Tuff produced the Grouse Canyon caldera; and two major ash-flow eruptions of the Timber Mountain Group produced the Timber Mountain caldera complex). The structural margin of the Ammonia Tanks caldera of the Timber Mountain caldera complex is shown nested within the composite topographic wall of the caldera complex in figure 5, and the buried Rainier Mesa structural boundary is not shown.

Different kinds of rocks are typically formed inside and outside the central foundered caldera block. In a normal eruptive cycle, the subsided intracaldera zone is filled by thick ash-flow deposits that solidify as welded tuff. Lava flows are commonly extruded into the caldera depression following the major ash-flow eruption; and intermittently thereafter, lavas may accumulate to great thickness, depending on the subsidence history of the caldera block. Outside the caldera, the main eruption produces thick sheet-form deposits of welded ash-flow tuff.

Over time, the center of activity in the volcanic field migrates laterally and another caldera-forming ash-flow eruption cycle is initiated. In this way, younger caldera structures cross-cut or overlap older volcanic units and boundaries. Volcanic ash from the younger eruptions commonly fills the relict volcanic landforms of the older, inactive calderas and forms deposits of nonwelded, bedded ash-fall tuff. These overlapping units commonly are altered to zeolite minerals and form confining units.

The subsurface of the Pahute Mesa underground test area is the location of two of the major buried calderas of the southwest Nevada volcanic field. Together these two calderas are known as the Silent Canyon caldera complex (fig. 5). The older Grouse Canyon caldera lies in the northeast, whereas the younger, larger, and exceptionally deep Area 20 caldera (more than $10,000 \mathrm{ft}$ ) underlies most of the Pahute Mesa test area (Orkild and others, 1969; Sawyer and Sargent, 1989). All testing has taken place within this Silent Canyon caldera complex, with the exception of a few events in the extreme northwest corner of the NTS.

Both the Grouse Canyon caldera (13.7 Ma; Sawyer and others, 1990 and 1994) and the Area 20 caldera $(13.3 \mathrm{Ma})$ were filled by interlayered thick postcaldera lavas and nonwelded tuffs in complex fashion. Lavas filling the Grouse Canyon caldera are from the Deadhorse Flat Formation of the Belted Range 


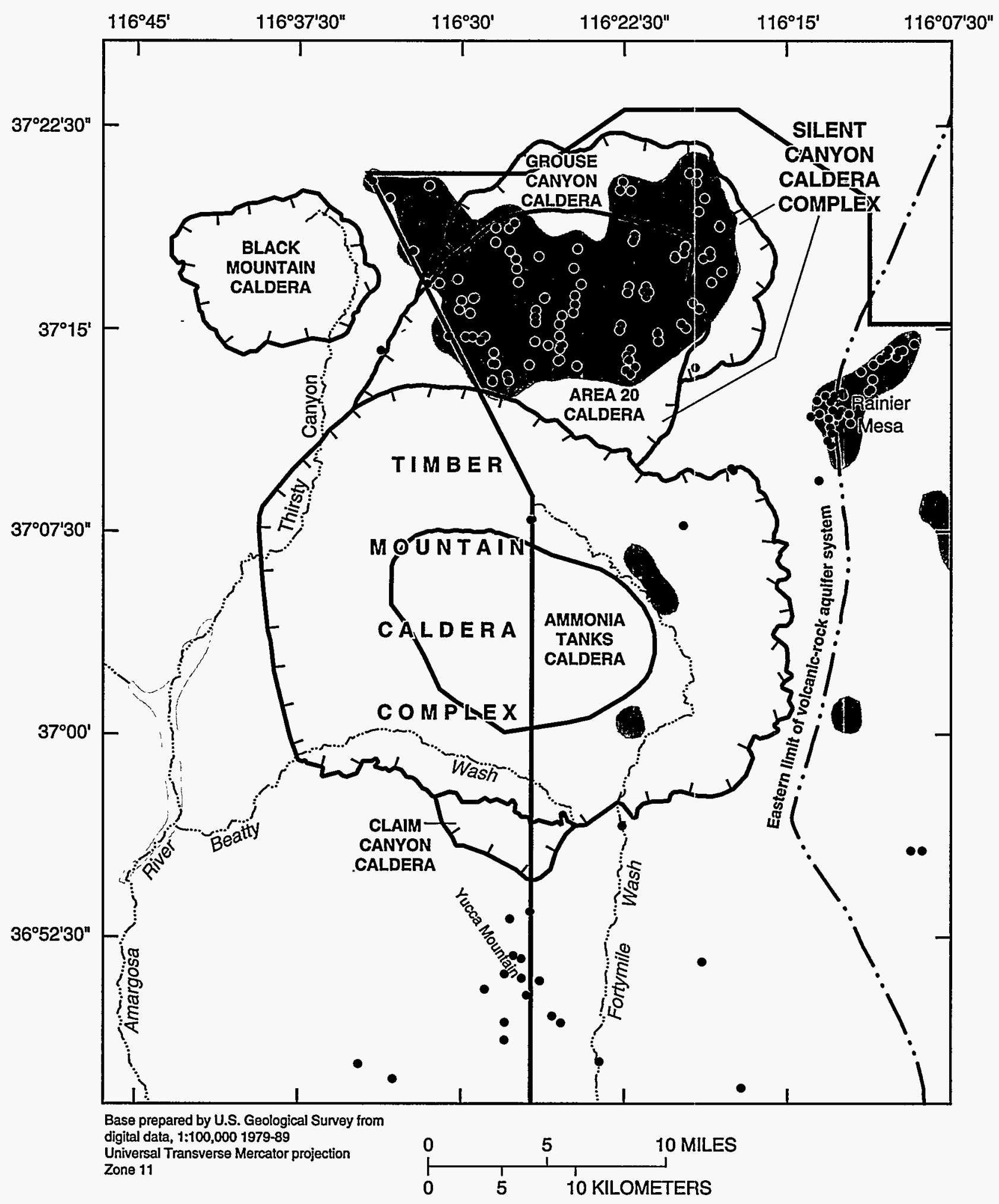

Figure 5. General features of volcanic-rock aquifer system in and adjacent to northwestern part of Nevada Test Site. Silent Canyon caldera complex and adjacent areas underlie Pahute Mesa. 


\section{EXPLANATION}

Oasis Valley discharge area

Underground test area

Caldera or caldera complex boundary-Modified from Sawyer and others, 1994

$-\cdots$

Eastern limit of area where volcanic-rock aquifers dominate ground-water flow-Coincides with divide between Alkali Flat-Fumace Creek Ranch and Ash Meadows ground-water subbasins (see plate 1)

Boundary of Nevada Test Site

- Well or test hole

Figure 5. Continued. 
Group (table 1), whereas those that fill the Area 20 caldera are from the Crater Flat Group and the Volcanics of Area 20 of the Calico Hills Formation. The entire Silent Canyon caldera complex was later buried by Timber Mountain Group ash-flows erupted from the Timber Mountain caldera complex to the south, and by Thirsty Canyon Group ash-flows erupted from the Black Mountain caldera to the west (fig. 5). The resulting extracaldera ash-flow tuffs are tabular sheets that form the tableland topography of Pahute Mesa and are generally unsaturated, except in the southwestern part of Area 20. The total thickness of the combined volcanic section is unknown, but exceeds $13,686 \mathrm{ft}$ at drill hole UE-20f (pl. 4, table 5) in northwest Area 20.

Ground water in the northeastern part of the Silent Canyon caldera complex occurs primarily within rhyolitic tuffs and lava flows of the Deadhorse Flat Formation inside the Grouse Canyon caldera (fig. 5, pl. 4). To the southwest, where the Grouse Canyon caldera is truncated by the outer wall (Area 20 topographic wall, pl. 4) of the Area 20 caldera, these same lava flows are overlain by unsaturated tuffs and lava flows of the Crater Flat Group (pl. 4). Typically, transmissivities are high in lava-flow aquifers within the upper $2,000 \mathrm{ft}$ of the saturated section (Blankennagel and Weir, 1973, p. 2). Lava-flow aquifers of the Deadhorse Flat Formation constitute the major water-bearing units in the northeastern part of the Silent Canyon caldera complex.

Upon crossing the inner wall (Area 20 structural margin, pl. 4) of the Area 20 caldera, the top of the saturated zone is primarily in rhyolitic lavas and tuffs of the Volcanics of Area 20 of the Calico Hills Formation (pl. 4). As in the Grouse Canyon caldera, rhyolite lava flows are the principal aquifers, but are more isolated in the Area 20 caldera by local confining units made up of nonwelded tuff. The lava flows have moderate transmissivities and the intervening nonwelded tuffs exhibit lower permeabilities, especially where they are zeolitized or argillized or both (Blankennagel and Weir, 1973, p. 7 and 17).

The degree of hydraulic connection between individual lava-flow aquifers in the Area 20 caldera is uncertain because the hydraulic characteristics of the nonwelded tuffs are poorly known and their distribution is complex. Nonwelded tuffs are quite thick where they have accumulated against the northeast wall of the Area 20 caldera, and in the upper part of the saturated section, may inhibit southwestward ground-water flow between the Grouse Canyon and Area 20 calderas. In the southwestern part of the Area 20 caldera, lava flows are thicker and more voluminous, and nonwelded tuffs are notably thinner; and hydraulic tests indicate that the lava flows act more as an interconnected, integrated aquifer (Blankennagel and Weir, 1973, p. 8-12 and 2122).

West of the West Boxcar fault (pl. 4), thick welded tuffs of the Paintbrush Group form the principal aquifers in the upper part of the saturated zone. These welded-tuff aquifers have moderate to high transmissivities, and wells completed in them have moderate to high specific capacities (Blankennagel and Weir, 1973, p. 12-17). The aquifers are underlain by lava-flow aquifers of the Volcanics of Area 20 of the Calico Hills Formation. The distribution of the Paintbrush Group welded-tuff units southwest of the NTS boundary is essentially unknown because drill-hole data are scant and structural projections cannot be made with confidence because of younger, covering units.

Northwest of the Silent Canyon caldera complex in the northwestern part of the Pahute Mesa test area, the top of the saturated zone lies within a thick welded ash-flow of the Rainier Mesa Tuff and Timber Mountain Group nonwelded tuffs (pl. 4). The underlying rocks are nonwelded tuffs of the Paintbrush Group, which regionally act as a confining unit. The altitude of the top of the saturated zone in the Rainier Mesa welded-tuff aquifer is several hundred feet higher than it is in the lava-flow aquifers east of the Silent Canyon caldera complex boundary. This difference suggests that the low-permeability Paintbrush Group tuffs act to inhibit hydraulic communication across the buried caldera wall (Blankennagel and Weir, 1973, p. 12-22; see next section "Ground-Water Flow").

The Rainier Mesa underground test area is enclosed within an unusually thick section of bedded, largely nonwelded tuffs that were deposited outside of the caldera-subsidence structures of the southwest Nevada volcanic field (fig. 5). The tuffs accumulated within a synformal trough that mimics the trace and form of a pre-existing topographic valley. In the axis of the trough, these tuffs measure more than $3,500 \mathrm{ft}$ thick at Rainier Mesa Exploratory-1 and Test Well 1, and appear to thin slightly toward the south.

Devonian dolomite crops out beneath the Rainier Mesa volcanic deposits along the east side, and similar rock has been found in vertical drill holes beneath the eastern half of the test area. Farther west, drill holes have penetrated fine-grained micaceous quartzites, which have been correlated with the Eocambrian Wood 
Canyon Formation on the basis of lithology and on the outcrop of Wood Canyon Formation rocks at the surface immediately northeast of Rainier Mesa in Gold Meadows (pl. 3). The completely buried boundary between micaceous quartzite and dolomite has long been interpreted as the trace of a Mesozoic thrust fault, which presumably dips westward (Houser and Poole, 1960; Carr, 1974; Caskey and Schweikert, 1992; Cole and others, 1994). The interpretation is supported by the fact that similar units are bounded by a thrust fault at the northern end of Bare Mountain (Monsen and others, 1990) along the general trend of pre-Tertiary structures in this area.

East and southeast of the Paleozoic carbonate exposures, the Eleana confining unit in the Eleana Range separates Rainier Mesa from Yucca Flat (pls. 1 and 3). The Eleana confining unit lies beneath the westdipping Tongue Wash fault and may underlie the Paleozoic carbonate rocks beneath eastern Rainier Mesa. As previously noted in the description of results from drill hole ER-12-1 (see section "Yucca Flat and Frenchman Flat-Hydrogeologic Units"), structural complexities in this area make it difficult to predict the distribution and hydrologic significance of Paleozoic rocks. Ground water beneath Rainier Mesa may flow only westward and southward within the Alkali FlatFurnace Creek Ranch subbasin or some part may flow eastward across or underneath the Eleana confining unit into the Ash Meadows subbasin.

\section{Ground-Water Flow}

Secondary permeability plays a major role in controlling the flow of ground water through the volcanic rocks of Pahute Mesa and Rainier Mesa. Permeability controls include joints and fractures (high permeability), zeolitic alteration of tuffaceous rocks (low permeability), and faults (both high and low permeability). Locations of subsurface inflow and areas of local recharge also influence the flow of ground water beneath the mesas. Ground-water flow is complicated by the discontinuous nature of the volcanic aquifers. and by major high angle Basin and Range faults and structural walls associated with intersecting and overlapping caldera complexes. Flow is primarily through interconnected fractures in the lava-flow and weldedtuff aquifers, and through faults that transect low permeability rocks. Flow is impeded primarily by zeolitized volcanic rocks (tuff confining unit), nonfractured crystalline parts of the lava flows (lava-flow confining unit), and faults that juxtapose less permeable against more permeable rocks.

Much of what has been conceptualized about ground-water flow beneath Pahute Mesa is based on water levels measured prior to 1970. Many of the earlier measurements were made in drill holes open to more than one hydrogeologic unit; thus, they represent composite water levels from different combinations of hydrogeologic units. The drill holes measured throughout the area are located primarily within and not along the margins of various fault blocks (pl. 4). Because many of the north-south trending, high-angle faults bounding these blocks offset hydrogeologic units at the water table, measurements represent water levels from a variety of different and discontinuous hydrogeologic units. Realizing the limitation of these measurements, Blankennagel and Weir (1973, pl. 1) contoured the early water-level data to gain additional insight into regional flow directions in and near Pahute Mesa (fig. 6). For the purpose of contouring, they had to assume that flow was primarily lateral through rocks in hydraulic continuity. This assumption disregards vertical flow components, and does not account for hydraulic discontinuities that are likely to result from the discontinuity of the volcanic rocks and the presence of faults and dikes.

Precipitation on Pahute Mesa and Rainier Mesa infiltrates downward, primarily through joints and fractures, to locally recharge the ground-water flow system. As water percolates down toward the regional water table, it commonly contacts low-permeability rocks. These local obstructions create saturated zones of perched and semi-perched water that can be elevated hundreds of feet above the regional water table. Perched water is widespread throughout the mesas, even in areas of low precipitation. The source of perched water within areas of lower precipitation is uncertain, but could be water that moved into the area from adjacent areas receiving recharge; older, occluded water that infiltrated downward during a past pluvial period; or water that was forced (injected) into these zones as a result of overpressure from underground detonations. Perched water slowly drains through the underlying confining unit to recharge the ground-water flow system. The rate of downward drainage is uncertain but would depend primarily on the hydraulic characteristics on the underlying confining unit. 


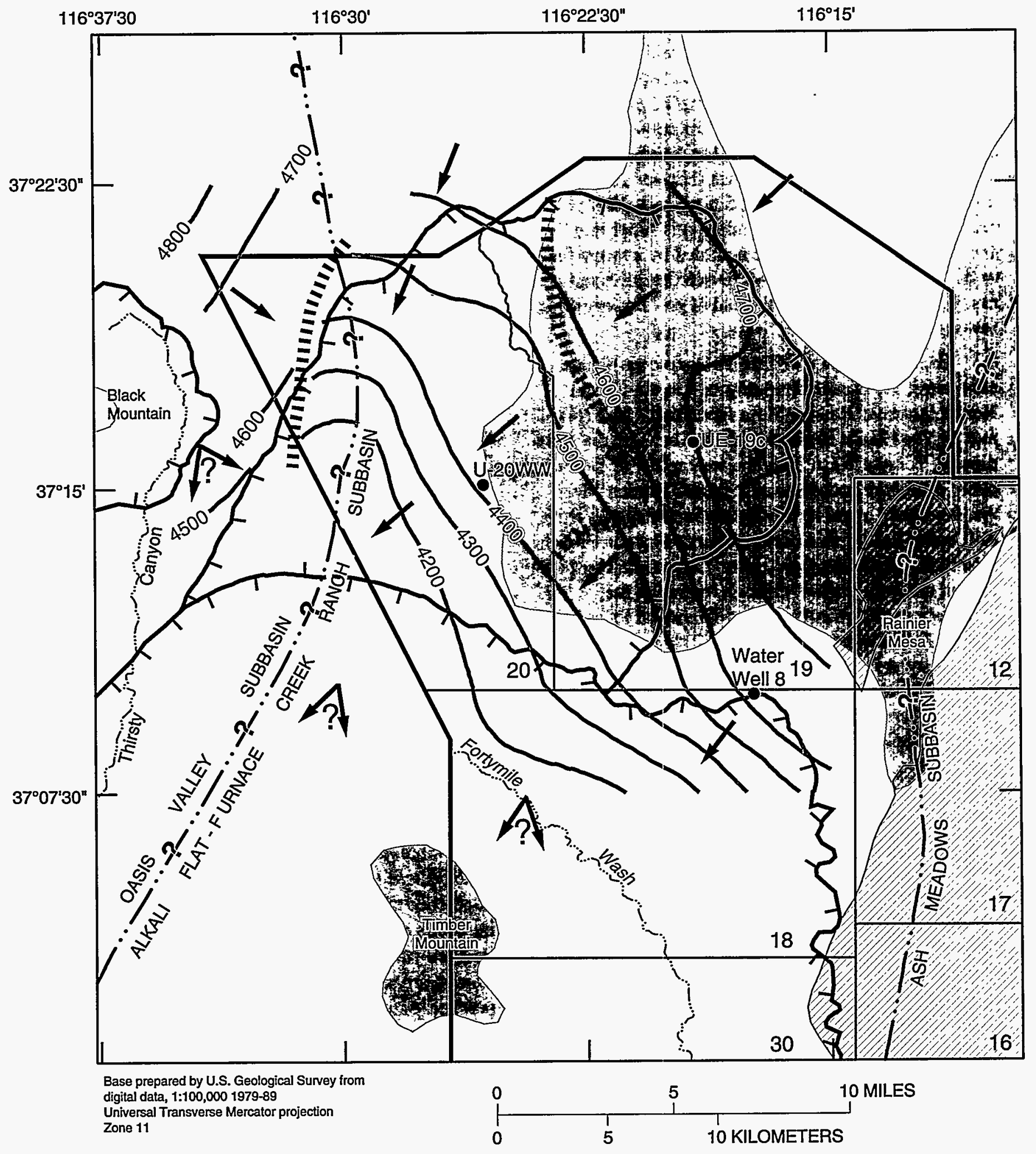

Figure 6. Major controls on ground-water flow in Pahute Mesa area. 


\section{EXPLANATION}

Area of ground-water recharge-See plate 1 for additional information

Known areal extent of Eleana and basement (quartzite) confining units at altitude of water table-Modified from Winograd and Thordarson (1975, plate 1)

Caldera-complex boundary-Modified from Sawyer and others, 1994. See plate 3 for additional information

- Water-level contour-Shows altitude of water level. Interval 100 feet. Datum is sea level. Modified from Blankennagel and Weir (1973, plate 1)

Boundary of ground-water subbasin-Modified from Waddell and others (1984, plate 3) and Winograd and Thordarson (1975, plate 1)

III I I I Limited-flow barrier-Modified from Blankennagel and Weir (1973, plate 1)

DF

IIIIII

UF

Boundary between area of upward flow (on west) and downward flow (on east)Modified from Blankennagel and Weir (1973, fig. 10)

General direction of ground-water flow-Queried where uncertain

\section{Boundary of Nevada Test Site}

18

Area boundary within Nevada Test Site-Area number is indicated

UE-19c

Water-supply well-Label identifies well

Figure 6. Continued. 
Estimated potential recharge from precipitation within Pahute and Rainier Mesas totals about 3,150 acre-ft/yr according to Blankennagel and Weir (1973, table 21). Their estimate is based on an empirical method developed for regional ground-water assessments in the arid southwest. The method assumes recharge is a proportional percentage of the total amount of precipitation that falls on an area (Eakin and others, 1951). Using this same empirical relation, Thordarson $(1965$, p. 73$)$ estimated recharge to the Rainier Mesa area at 140 acre-ft/yr. Recharge through a part of Rainier Mesa was estimated by Russell and others (in press) by measuring discharge at a tunnel portal and applying a budget-type analysis. Their results were in close agreement with the empirically derived estimates. Local recharge not only is a major source of water to the aquifers beneath Pahute Mesa and Rainier Mesa, but also is the primary mechanism by which contaminants introduced into unsaturated rock could be transported downward into the regional ground-water flow system. However, the distribution, rate, and quantity of recharge are known only in general terms.

Another potential source of recharge is ponds that contain water drained during tunneling operations at Rainier Mesa (fig. 2). Much of the water impounded by these ponds evaporates to the atmosphere, but some may leak downward, ultimately recharging the regional ground-water flow system. The infiltration of ponded water would be at most a minor source of water to the regional flow system, but might provide a means by which surface contaminants contained in the ponded water could be transported into the subsurface environment.

Subsurface inflow from Kawich Valley and Gold Flat to the north is the largest source of ground water into the test areas. Blankennagel and Weir $(1973$, p. 20) estimate this source at 5,500 acre-ft/yr. The estimate is based on a limited knowledge of geologic and hydrologic conditions north of Pahute Mesa and Rainier Mesa testing areas. Further quantification of this source would require geologic and hydrologic information from Kawich Valley and Gold Flat.

Water levels measured in and around Pahute Mesa range in altitude from about $4,700 \mathrm{ft}$ in northeastern part of the mesa to about $4,100 \mathrm{ft}$ in the southcentral part of the mesa (fig. 6, pl. 4, and table 5). Hydraulic gradients derived from water-level contours (Blankennagel and Weir, 1973, pl. 1) indicate that ground water flows south-southwest across central
Pahute Mesa away from the areas of recharge and subsurface inflow. Lower water levels in the central part of the mesa are bounded by higher levels to the west, creating what appears to be a local drain open to the south in western Area 20 (fig. 6). Blankennagel and Weir (1973, p. 24) suggest the feature may result from a limited-flow barrier created by caldera-boundary faults juxtaposing low-permeability rocks on the west against more permeable rocks on the east. The presence of low permeability rocks diverts westward moving water to the south. The hydraulic gradient across the barrier, calculated on the basis of water levels measured on both sides of the feature, indicates some eastward flow across the barrier, but quantities would be limited by the low permeability of the juxtaposed units. Other interpretations of contours west of the feature suggest a much more southward direction of flow (Savard, 1990). These interpretations maintain the barrier concept, but suggest even lesser amounts of flow across the barrier. The barrier concept also is supported by distinct differences in the major anion chemistry of ground-water samples collected east and west of the feature. Samples collected west of the partial-flow barrier exhibit a much higher sulfate content. Blankennagel and Weir (1973) use this feature to support their conclusion that caldera-boundary faults may be major controls on ground-water flow. Although the feature seems to be a significant control on ground-water flow in the local area, its existence and hydrologic significance beyond the immediate area is uncertain.

Hydraulic gradients derived from water-level contours (Blankennagel and Weir, 1973, pl. 1) indicate that ground water leaves the test areas along the southern margins of the mesas (fig. 6). On the basis of these gradients, an estimate of outflow across these margins is 8,000 acre-ft/yr (Blankennagel and Weir, 1973, p. 20). In the areas downgradient of the testing, flow directions are inferred from more regional concepts because few data are available. Ground water leaving the testing areas across the southern margins of the mesas flows southwestward toward the Amargosa River in Oasis Valley, and south across Timber Mountain or down through Fortymile Canyon (pl. 1), ultimately discharging at either Oasis Valley, Alkali Flat, or Death Valley. The location and nature of the boundary separating the Oasis Valley and Alkali Flat-Furnace Creek Ranch subbasins, shown on plate 1, is not well understood; therefore, it is uncertain how much of the water discharging at Oasis Valley actually passed through rocks beneath the Pahute Mesa test area. 
Major structural features related to Tertiary extensional faulting and the formation of the Silent Canyon and Timber Mountain caldera complexes are known to exist between the underground test areas and the downgradient discharge areas. As discussed previously, these structures can act either as barriers that divert flow or conduits that convey flow. Few data are available to determine the effects that these major structures may have on ground-water flow directions and rates.

Water-level contours, shown on plates 1 and 3, indicate a southeastern flow component away from Rainier Mesa toward Yucca Flat. Ground water flowing toward Yucca Flat contacts low-permeability rocks of the Eleana confining unit. Few data are available to determine the effectiveness of this confining unit as a barrier or whether permeable rocks (lower carbonaterock aquifer) existing at depth provide a direct pathway for flow into Yucca Flat. Subsurface flow into Yucca Flat from the volcanic-aquifer system across the Eleana confining unit and through any underlying rocks has been estimated at no more than $200 \mathrm{acre}-\mathrm{ft} / \mathrm{yr}$ (Winograd and Thordarson, 1975, p. 94).

The only other identified outflow from volcanic aquifers that underlie the Pahute Mesa and Rainier Mesa test areas is by the withdrawal of water from wells for local water supply (fig. 6). Wells presently withdrawing water are U-20 Water Well, U-19c, and Water Well 8 (formerly Test Well 8). These wells provide water primarily to support operational activities, although water pumped from Water Well 8 also is used for consumptive purposes. Another well, UE-20n 1 (pl. 4, table 5), has been pumped intermittently for water samples for a radionuclide migration experiment. Recent withdrawals from these wells average about 750 acre-ft/yr, but have varied throughout the period of record according to local needs (D.B. Wood, U.S. Geological Survey, written commun., 1991). Although contaminants have not been detected at the supply wells, it is possible that at some future time these or other wells withdrawing water from volcanic rocks beneath these mesas could intercept or induce movement of test-generated contaminants.

Blankennagel and Weir (1973, p. 24) estimate that, on average, ground water beneath Pahute Mesa flows through the upper 3,500 ft of saturated rock. By testing specific intervals of volcanic rock within boreholes, they identified vertical differences in water levels, water chemistry, and water-transmitting properties. The maximum measured vertical difference in water level exceeded $200 \mathrm{ft}$ at UE-20f (pl. 4). Data indicate that water levels generally increase in altitude or are stable with depth throughout the central and western parts of Pahute Mesa and decrease in altitude throughout the eastern part of Pahute Mesa. They interpreted the spatial distribution of vertical changes in water levels to imply a downward flow in the eastern part of Pahute Mesa, which is consistent with the area of inferred recharge (fig. 6).

Hydrologic test results indicated that jointed and fractured welded tuffs and lava flows generally were the most permeable and zeolitized tuff the least permeable units. From the information presented, Blankennagel and Weir (1973) conceptualized a threedimensional framework of semi-independent aquifers separated from each other by confining units, where flow within the aquifer is primarily through fractures, and through interstitial pores in the confining unit between aquifers. The dominant water-transmitting units are areally extensive lava-flow aquifers in the northeast and central parts of Pahute Mesa and weldedtuff aquifers in the western part of the mesa (pl. 4). The continuity of individual hydrogeologic units and the hydraulic connections between aquifers are highly uncertain.

Recently measured water levels are in general agreement with those presented in Blankennagel and Weir (1973, pl. 1), although some anomalous levels have been measured (p1. 4, table 5). Anomalies could represent actual changes from earlier conditions and may be related to nuclear testing, changes in climatic conditions, equilibrium adjustments, or tectonic events. Another likely explanation, at least for some of these anomalies, is that they represent conditions in hydrogeologic units different from those penetrated by the earlier drill holes. The more recent water levels were measured in drill holes that generally penetrate less than a few hundred feet of saturated rock. Most earlier water levels (prior to 1975) were measured in deeper drill holes that penetrated much thicker sections of saturated rock; many of these drill holes are no longer available. The specific cause or causes of these anomalies is difficult to establish based solely on the data available.

Few estimates of ground-water flow rates through the volcanic aquifers are available in the literature. An estimate of the average ground-water velocity through the volcanic rocks beneath Pahute Mesa is given by Blankennagel and Weir (1973). The estimate is based on some simplifying assumptions about hydraulic and physical characteristics of the flow system, and is given 
as a range from 7 to $250 \mathrm{ft} / \mathrm{yr}$ to account for uncertainties in the hydraulic properties related to whether flow occurs through fractures or interstitial pore space or both. Brikowski $(1992$, p. 18) estimates a minimum flow rate of $90 \mathrm{ft} / \mathrm{yr}$ and maximum flow rate of $124 \mathrm{ft} / \mathrm{yr}$ through a lava-flow aquifer near the Cheshire event (drill hole U-20n on pl. 4). The estimates are based on tritium arrival times in a drill hole about $1,000 \mathrm{ft}$ away from the Cheshire event. Tritium was detected in the initial samples taken 11 years after the event. The maximum rate is given to account for the earlier arrival of tritium. The flow rate for water moving through unsaturated tuff (local recharge) at Rainier Mesa was estimated between 80 to $1,300 \mathrm{ft} / \mathrm{yr}$ by Thordarson (1965, p. 74-75). His estimate was based on tritium residence times, and is given as a range to account for uncertainties in the dating of the samples and for uncertainties concerning the path taken to reach the sampling point.

The flow of ground water through this complex framework of aquifers and intervening confining units, although assumed to be fracture controlled, is not fully understood because (1) the difficulty associated with predicting the subsurface distribution of volcanic units; (2) a lack of understanding about fracture density, orientation, and openings; (3) limited data on hydrologic conditions (water levels and water chemistry) within individual aquifers; and (4) limited information on the hydraulic properties of the many hydrogeologic units comprising the framework. A key question yet to be resolved is whether ground water discharging at Oasis Valley passed through rocks beneath the area of underground testing on Pahute Mesa. This potential flow path represents the shortest route for test-generated contaminants to reach the accessible environment. Because the more recent drill holes provide minimal information on the vertical differences in hydrologic conditions, few data are available from which to advance the understanding of ground-water flow beyond that presented by Blankennagel and Weir (1973), or to determine confidently whether testing has effected ground-water conditions.

\section{Effects of Underground Testing on Ground-Water Flow}

The preceding sections of this report have described the geology and hydrology of the region and of the test areas as they existed prior to the initiation of underground testing. Large explosions, especially those that take place near or below the water table, change local hydrologic conditions and are known to have significant effects on rock permeability, storativity, interstitial fluid pressures, mineral transformations, temperature, and water composition. Data indicate that ground-water flow rates and directions also may be altered, although the extent, duration, and magnitude of these changes can only be stated in general terms. This section summarizes what has been learned and some of what can be inferred about the effects of testing and its influence on ground-water flow. Much of this information about the thermal-mechanical aspects of underground explosions is based on work by Piper and Stead (1965), Boardman (1970), Higgins (1970), Rogers (1970), and Carroll (1981).

Test-induced changes in permeability and storativity result primarily from the generation of new fractures, the formation of a cavity, and the eventual collapse to produce the rubble chimney (fig. 7). The plasma and thermal pulse that originates from the point of detonation expands rapidly outward within milliseconds of firing as rock is vaporized, melted, and mechanically disaggregated. This more-or-less spherical volume in which the rock is totally reconstituted is designated the cavity. A compressional shock wave propagates beyond the cavity and induces the formation of new fractures and causes slip on pre-existing fractures. Elastic rebound around the cavity region produces circumferential (hoop) compressional stress conditions immediately outside the cavity that hold these fractures closed until cavity pressures drop as the radioactive melt condenses to glass and as other volatiles (chiefly water) condense to liquid. As the compressional hoop stress decays with the reduction in cavity vapor pressure, the cavity roof caves and collapse continues upward as a rubble column (called the chimney) is formed. Chimney collapse may happen within minutes of firing or may not occur for hundreds of days depending on rock strength, overburden pressure, and other variables. Collapse may extend upward only a short distance or all the way to the ground surface creating a subsidence crater. The rubble chimney may be a zone of enhanced permeability and storativity, on the basis of several direct and indirect measurements (Boardman and Skrove, 1966; Cherry and others, 1968; Delort and Supiot, 1970; Holzer, 1970; Lombard and others, 1970; Terhune, 1973), but hydrologic effects of the chimney on the ground-water flow system have not been systematically investigated. 
MECHANICAL EFFECTS

Land surface

EXPLANATION

Glass condensed from vaporized rock and test material

Zone of intense crushing

Zone of pervasive fracture-Melt injection along fractures

Zone of moderate fracture, with discrete shear fallure-Widespread new fractures formed

Zone of chimney collapse immediately following detonation

Zone of subsequent chimney collapse

Zone of elastic deformation

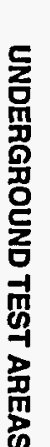<smiles>C1=CCCCCC1</smiles>

CR

Point of detonation within cavity

Cavity radius-Unit of distance outward from point of detonation at center of cavity

\section{HYDROLOGIC EFFECTS}

Schematic changes in the potentiometric surface over time near detonation

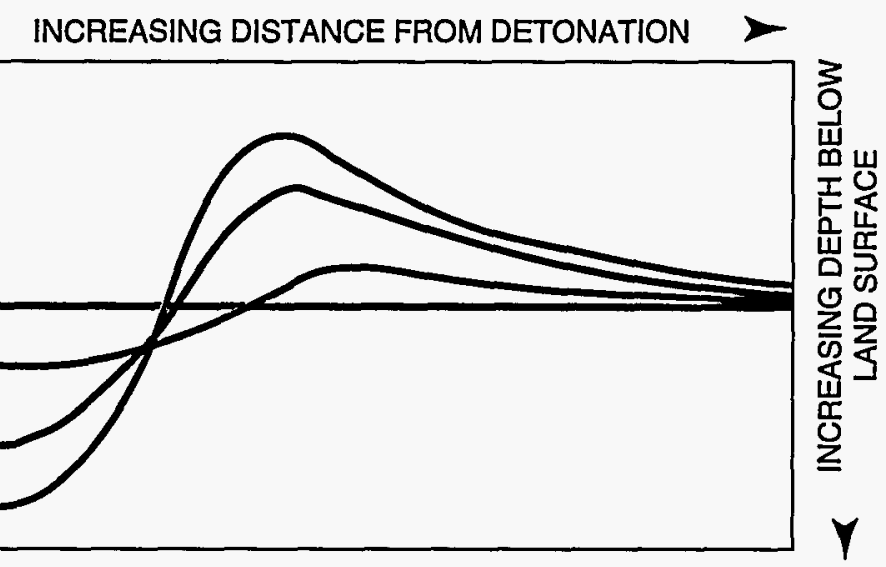

\section{EXPLANATION}

Potentiometric surface

Before detonation (static water level) Several days after detonation Several months after detonation Several years after detonation

Note: Actual time depends on local permeability, recharge, rate of flow, and other factors

Figure 7. Diagrammatic section showing mechanical and hydrologic êffects that may result from underground test detonated below water table. 
Zones of new fractures around the cavity also are inferred to have hydrologic properties that differ considerably from pre-test conditions. The range over which fracturing and other deformation takes place is a function of the energy released (nuclear yield), and the radius of the cavity is the parameter most commonly stated as a scaled measure of the range of these effects. Actual measurements of cavity radius, obtained from post-shot holes drilled through the cavity into the radioactive glass at the base, range from about 50 to $200 \mathrm{ft}$ for 20 to 150 kiloton events, and from 200 to more than $350 \mathrm{ft}$ for larger events (Hudson and Smith, 1981). However, these direct measurements also show that cavities have significant irregularities and that radii vary by as much as 15 percent along different transects. The following description, therefore, implies no greater precision of scaled range.

Intensely pulverized rock extends outward to about 1.3 cavity-radii, and pervasively fractured rock extends outward beyond this zone to about 2 cavityradii on the average (Carroll, 1981), but to greater ranges laterally and above the point of explosion (Boardman and others, 1969). Higgins (1959) and Derlich (1970) indicate that these interior zones may actually become less permeable than the native (pre-shot) rock because of the tight compaction induced by the compressional shock wave. Radioactive molten rock is locally injected from the cavity along fractures into this zone, promptly at the time of detonation, but the absolute range of injection has not been quantified. Farther out, a surrounding zone of more widely spaced fracturing extends to about 2.5 to 5 cavity-radii (Borg and others, 1976, p. 84). Fractures in this zone have been shown to increase permeability in granitic rocks (Boardman and Skrove, 1966; Derlich, 1970). Preexisting fractures have shown local test-induced offsets out to a range of 6 to 11 cavity-radii in Rainier Mesa tunnels, and surface displacements are documented on Pahute Mesa out to a range of 10 to 20 cavity-radii (Dickey, 1968; Snyder, 1971; Maldonado, 1977; Covington, 1990). Possible effects on permeability due to test-induced movement along pre-existing fractures has not been studied.

Sustained documented changes in pre-shot water levels attributed to underground testing include lowered levels within the chimney region and elevated levels outside the chimney (fig. 7). Post-shot water levels within the rubble chimney of tests detonated below the pre-shot water table have been hundreds of feet lower than pre-test levels (Thordarson, 1987, p. 12-16).
Declines within the chimney have been attributed to increased drainage through the more porous rubble and to the expulsion of water by the explosion (Garber, 1971 , p. 207). Water levels measured outside the chimney region have been hundreds of feet higher than preshot levels, and the increase differs with distance from the detonation and with rock properties (W.E. Hale, I.J. Winograd, and M.S. Gabel, U.S. Geological Survey, written commun., 1963; Thordarson, 1987; Hawkins and others, 1989). Measurements during and following a few tests suggest that an annular mound of higher water levels forms immediately following detonation, and then begins to dissipate by drainage outward into surrounding rock and inward to the chimney region (Garber, 1963, p. 207; Thordarson, 1985, 1987). The initial rise in water level beyond the rubble chimney has been attributed to decreases in porosity due to inelastic compression of the rock (Knox and others, 1965, p. 824; Burkhard and Rambo, 1991). Continued outward drainage of water creates a water-level rise, which migrates outward with time. The magnitude of the rise generally decreases with distance from the cavity and time. The limited data available indicate that test effects may last for a few months or may continue to persist over many years before equilibrium is again reached (Thordarson, 1987).

Numerous short-term, water-level oscillations have been noted and attributed to the initial test-generated pressure wave; to seismic-type responses associated with chimney collapse; to test-induced seismicity; . or to test-induced fracturing. These small-magnitude changes have been measured at distances in the tens of miles away from the point of detonation (Dudley and others, 1971), but are of minor significance in terms of regional ground-water flow.

The wide variations in duration and areal extent of altered hydrologic conditions probably reflect variations in hydraulic communication among local hydrogeologic units, but no systematic studies have been made. The cumulative effects of these changes on ground-water flow: rates and directions have not been assessed. Measurements of hydraulic properties and water levels within any of the underground test areas since testing began, therefore, cannot be presumed to represent the undisturbed hydrologic conditions. 


\section{Yucca Flat and Frenchman Flat}

The large number and close spacing of underground tests in Yucca Flat increases the probability that mechanical effects of adjoining tests have interacted in some parts of the basin (fig. 8). No direct investigations of cumulative effects have been made, but some qualitative inferences can be stated. Fractures created by prior tests are likely to be reactivated by later events and intersecting fracture zones ( 2 to 5 cavity-radii) or chimney rubble columns beneath the water table will likely increase the hydraulic connection between hydrogeologic units and create additional pathways for ground-water flow. New fractures and collapse chimneys in the unsaturated zone above test locations may enhance downward recharge from the surface and migration of contaminants toward aquifers, especially in areas where subsidence craters can capture and pond surface runoff. Fracturing of the radioactive glass cavity-lining of prior tests by shock waves from later explosions has not been studied, but it is likely that the leachable surface area of the glass could be increased.

The hydrologic effects of underground testing in Yucca Flat include long-term increases in the watertable altitude in some areas, and persistent increases in hydraulic pressure in some confined units (Hoover and Trudeau, 1987). The region of elevated water table (referred to as water-table mounding) is currently limited to the north-central part of Yucca Flat (fig. 9), where it appears to result from post-test compaction of saturated, unconfined alluvium (Hoover and Trudeau, 1987). Farther south in the basin (fig. 9), wells that penetrate confined aquifers show anomalously high hydraulic pressures, and water levels have been measured at discrete depths within the tuff confining unit that are hundreds of feet higher than expected (Hoover and Trudeau, 1987; Hawkins and others, 1988, 1989). The cause of the these high hydraulic pressures is uncertain. Trapped pressures accumulating as a consequence of repeated underground tests detonated in saturated, low permeability rocks is one likely explanation. These test-induced pressure changes have altered substantially pre-test hydraulic gradients and probably have created local anomalies in both vertical and lateral flow rates and flow directions. The consequences of such changes on local or regional groundwater flow have not been fully determined, but would be expected to complicate the conceptual model of ground-water flow, especially beneath the areas of underground testing.

\section{Pahute Mesa and Rainier Mesa}

The effects of underground testing on groundwater flow at Pahute Mesa and Rainier Mesa are less studied than those described for Yucca Flat. Elevated water levels have been measured, but because of numerous factors (see "Ground-Water Flow"), most notably the presence of perched water, the anomalous highs are difficult to attribute to testing. Despite less quantitative information, it is possible to qualitatively state that the hydrologic concerns associated with testing are considerably different from those that pertain to tests detonated in Yucca Flat. These differences can be attributed to variations in the local geology and hydrology of the two test areas, and to the larger yields, greater depths, and the lesser number of tests on the mesas.

Pahute Mesa was the site for most of the larger yield tests at NTS, most of which were detonated near or below the water table (tables 4 and 5, pl. 4). An estimated 19 megatons of cumulative explosive yield can be ascribed to Pahute Mesa shots that contributed to "the ground-water-accessible radionuclide inventory" (Bryant and Fabryka-Martin, 1991, table 2), and to more than two-thirds of the NTS total. All 18 highyield tests at the NTS (approximately 200 kilotons to about 1.4 megatons), detonated prior to the 1976 Threshold Test Ban Treaty, were more than $800 \mathrm{ft}$ below the pre-test water level. From these factors, four issues warrant consideration at Pahute Mesa: (1) larger yields produce larger cavities that enclose more diverse hydrogeologic units; (2) the extent of fracturing around larger tests, and the effects on permeability, cannot be evaluated from present data; (3) larger cavities and larger zones of fracturing increase the likelihood that conditions in multiple aquifers are altered, and interactions among such units may be complex; and (4) larger yields produce more tritium and fission products that are readily accessible to ground water.

Most Rainier Mesa tests involve small-yield devices (generally 20 kilotons or less) that were detonated in mined chambers above the regional water table. However, Rainier Mesa is an area receiving sufficient precipitation to be considered a recharge area and is known to contain zones of perched water. Downward percolating water may contact test-generated contaminants prior to reaching the underlying regional ground-water flow system. Presently, data are insufficient to determine whether test effects increase or decrease the rate of ground-water recharge or to 


$$
\text { FEET }
$$

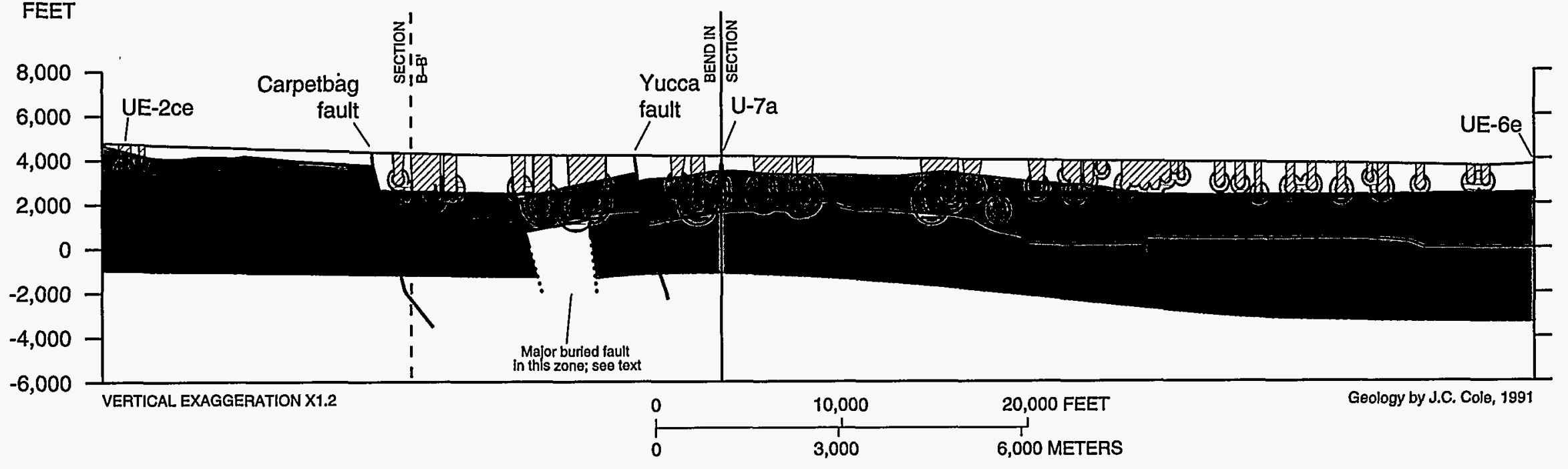

\section{EXPLANATION}

Valley-fill aquifer

Volcanic-rock aquifer and tuff confining unit

Upper carbonate-rock aquifer (schematic)

Eleana confining unit

Lower carbonate-rock aquifer
Zones of test-induced fractures

Pervasive fracturing

Moderate fracturing
Fault

Water tabla prior to underground testing-Modified from Doty and Thordarson (1983)

Figure 8. Generalized longitudinal hydrogeologic section across central Yucca Flat showing mechanical effects of underground testing. Underground test locations obtained from U.S. Department of Energy (1994). Cavity dimensions and fracture zones calculated using measurements of cavity radius and working-point depths as summarized in classified listing of test parameters (Lawrence Livermore National Laboratory, written commun., 1991). Location of sections is shown in figure 9. 

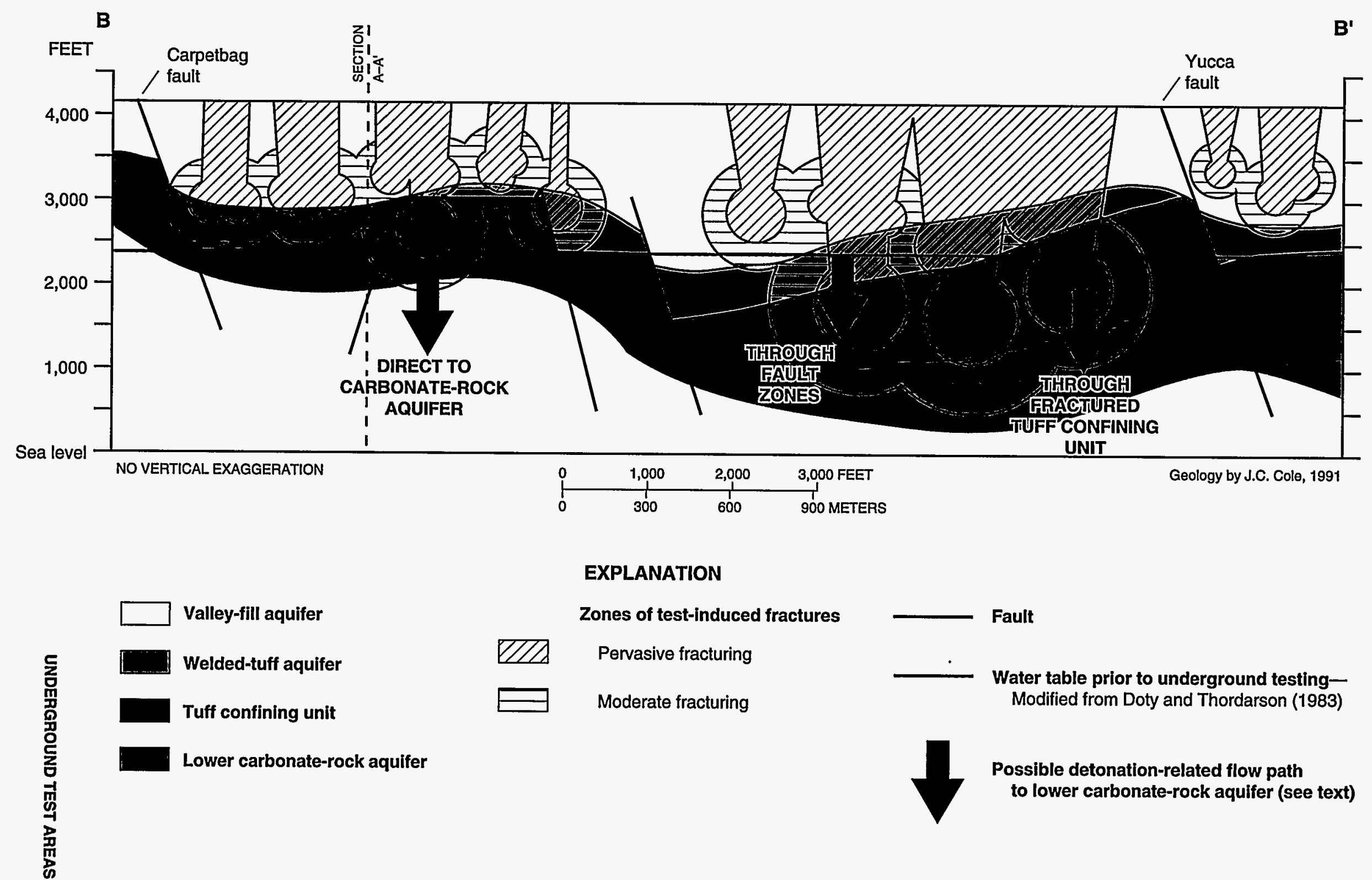

$\pm \quad$ Figure 8. Continued. 


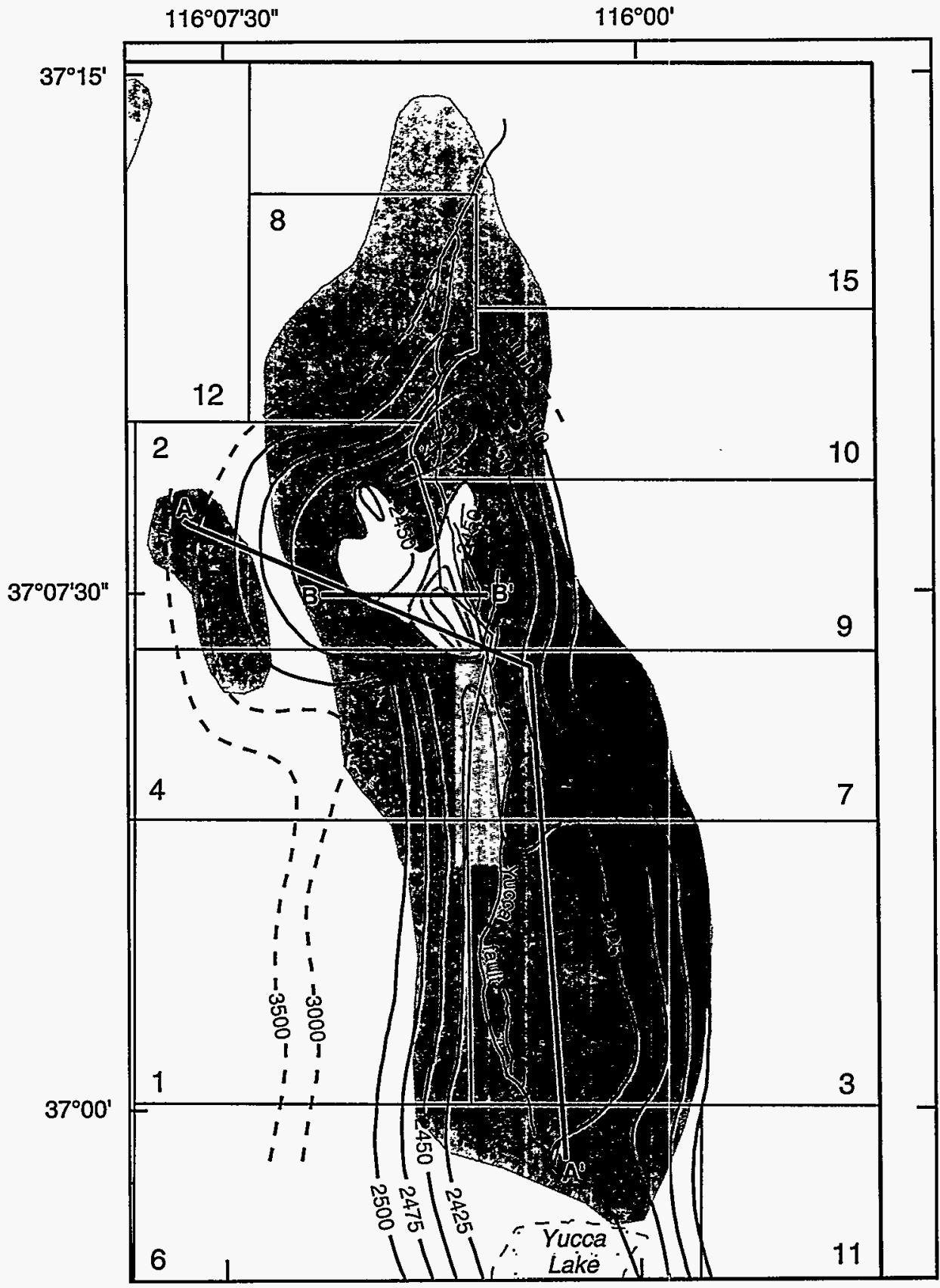

Base prepared by U.S. Geological Survey from digital data, 1:100,000 1979-89 Universal Transverse Mercator projection Zone 11

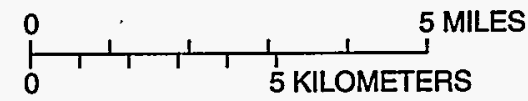

Figure 9. General areas within Yucca Flat where sustained, local hydrologic effects may have resulted from underground testing. 


\section{EXPLANATION}

\section{Approximate area used for underground testing}

Area of water-table mounding-Approximate area where water table is mounded in measured wells. Modified from Hoover and Trudeau (1988, p. 366 and fig.1)

Area of increased hydraulic pressure-Approximate area where water levels measured in tuff confining unit are higher than measured water table. Modified from Hawkins and others (1987)

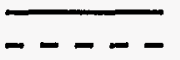

Water-table contour-Shows altitude of water table. Contour intervals 25 feet (solid line) and 500 feet (dashed line). Datum is sea level. Modified from Doty and Thordarson (1983)

$B \longrightarrow B^{\prime}$

Line of section-Sections are shown in figure 8

Nevada Test Site boundary

8

Area boundary within Test Site-Area number is indicated

Figure 9. Continued. 
determine their effects on contaminant transport. Chimneys that form above Rainier Mesa tests generally do not collapse to the ground surface, and contrary to conditions on Yucca Flat, few subsidence craters exist to create potential conduits for the downward infiltration of ponded surface runoff.

\section{SUMMARY AND CONSIDERATIONS FOR ENVIRONMENTAL RESTORATION}

Underground testing of nuclear weapons at the Nevada Test Site has introduced significant quantities of radioactive and chemical contaminants into the ground-water flow system of southern Nevada. These contaminants are distributed over a large area and a wide range of depths and in hydrogeologic environments that are variable and complex. Ground-water flow is the primary mechanism by which contaminants can be transported away from the underground test areas into a more accessible environment (areas of spring discharge and ground-water withdrawal) within and outside NTS boundaries. Therefore, any assessment of risk to human health or environmental quality resulting from exposures to test-generated contaminants must rely on quantitative knowledge of the ground-water flow system and the processes controlling contaminant transport.

This review and summary of existing information expands the regional and local hydrogeologic concepts established by previous investigators. NTS is centrally located in the regional Death Valley ground-water flow system. Ground water generally flows southward across southern Nevada to discharge areas primarily west and southwest of NTS. Most ground water originates from precipitation falling on the mountainous areas of central Nevada and to a lesser degree on higher mesas and mountain ranges along downgradient flow paths. Relative to NTS, ground water enters laterally across the northern and eastern boundaries of the site, and vertically beneath areas of higher elevation. Ground water leaves the NTS primarily across its southern and southwestern boundaries, ultimately reaching an intermediate discharge area or Death Valley, where it is released as springflow or is evaporated or transpired, unless otherwise removed by local pumping.

Ground water at NTS is thought to flow within one of three discrete ground-water subbasins. The western Oasis Valley subbasin, although not well studied, conveys ground water southward across the extreme northwest part of NTS through welded-tuff and lava-flow aquifers into Oasis Valley, where it is discharged by numerous springs and seeps and a few water supply wells. The central Alkali Flat-Furnace Creek Ranch subbasin, which includes most of Pahute Mesa test area, contains the rest of the western half of NTS. Ground water flows southward, first traversing complex, nested volcanic caldera structures that contain hydrologically diverse lavas, welded tuff, and bedded tuff, and later passes through alluyium and carbonate rock before discharging at Alkali Flat or the Furnace Creek Ranch area of Death Valley. The eastern Ash Meadows subbasin encompasses much of the eastern half of NTS, and includes the Yucca Flat and Frenchman Flat test areas. Ground water is conveyed primarily through the lower carbonate-rock aquifer, which is recharged locally from overlying alluvial and volcanic deposits that fill major valleys, and discharges primarily along a line of springs in Ash Meadows.

The boundaries between these subbasins are not well defined and are the subject of considerable scientific debate. Water budgets for individual subbasins have been derived from simple calculations based on regional estimates of recharge and discharge. Groundwater flow rates have been estimated on the basis of a few quantitative measurements, limited chemical and isotopic investigations, and a few model calculations, all which depend on regional assumptions about the flow processes. Porous (matrix) flow through quartzite, shale, and zeolitically altered tuff has been determined to be quite slow (less than $0.1 \mathrm{ft} / \mathrm{d}$ ), whereas flow rates through fractured carbonate rock have been measured to be several orders of magnitude higher (hundreds of feet per day). Most flow is assumed to occur through fractures and fault zones, but few systematic studies have been completed to understand or quantify this process.

The geology of the Death Valley ground-water flow system, and in particular the NTS region, is complicated by the overlapping effects of major structural events. The Eocambrian and Paleozoic bedrock of the region, consisting of a thick lower quartzite unit, a middle limestone and dolomite unit, and an upper siltstone, conglomerate, and shale unit of Mississippian age, were folded and thrust toward the east and southeast during Mesozoic time and locally thrust westward as well. Subsequent extensional deformation on low angle faults and erosion produced a complex distribution of rock units during the Tertiary period. Middle Miocene 
time was heralded by major rhyolitic eruptions from the earliest calderas of the southwest Nevada volcanic field that buried the pre-existing topographic surface formed on the Paleozoic rocks. Volcanic eruptions continued over a period of about 8 million years from several nested calderas beneath the Pahute Mesa and Timber Mountain areas, and led to the accumulation of many thousands of feet of varied rhyolitic deposits covering a Paleozoic basement. During and following this period of extremely active volcanism, the NTS region has been intermittently extended by slip on lowangle normal faults. Deep alluvial basins formed in the areas of greatest extension and filled with eroded debris from surrounding fault blocks. The geology within major areas of testing is well known as an outgrowth of drilling and investigations related to the underground testing program, but is considerably less clear beneath and beyond specific areas of testing.

Expanding the current understanding of geology and hydrology in individual underground test areas requires a knowledge of processes and parameters at a more detailed scale than used to describe regional ground-water flow. This more local scale is particularly relevant in assessing the potential for contaminant migration because so many of the critical hydrogeologic factors are characterized by heterogeneities over distances of a few feet to a few miles. Ground-water flow is influenced by lithologic discontinuities (resulting from depositional facies, lithification, alteration, and others) and hydrologic parameters (local recharge, discharge, pumping, and aquifer geometry, among others) that can be quite diverse over a testing area or even at the scale of an individual drill hole. In addition, mechanical, chemical, and hydrologic effects of a nuclear detonation, which determine the initial distribution of contaminants and alter the geologic environment as well as local hydrologic conditions, also make this scale particularly relevant.

Most underground testing at NTS was done in two distinct geologic and hydrologic environments. The Yucca Flat and Frenchman Flat test areas lie within the Ash Meadows ground-water subbasin where most tests were detonated in alluvium and volcanic rock overlying the regional carbonate-rock aquifer. In the Pahute Mesa and Rainier Mesa areas, where the definition of effective aquifers are poorly understood and the downgradient pathways are uncertain, tests were detonated in thick, highly varied volcanic rocks. Tests detonated in tunnels at Rainier Mesa and at some of the smaller test areas were all essentially in unsaturated rock, and are secondary in terms of ground-water contamination and potential offsite migration, except possibly in areas of local recharge where test-generated contaminants could be transported into the groundwater flow system through the unsaturated zone by downward percolating water.

Yucca Flat has been the location for about 80 percent of the underground tests, although two-thirds were relatively small in yield and detonated above the water table. The remaining third were detonated near and below the water table primarily in bedded tuff east of the Carpetbag fault in the eastern part of the west-tilted Yucca Flat structural basin. The lower carbonate-rock aquifer lies below these tuff units and forms the primary conduit by which water can leave the basin. Ground water flowing within the lower carbonate-rock aquifer is constrained on the east by a regional southwest hydraulic gradient and on the west and north by the low permeability rocks. Thus, ground water flows southward into Frenchman Flat, ultimately reaching a downgradient discharge area, probably Ash Meadows. The lower carbonate-rock aquifer receives local recharge across the overlying tuff units, most of which have been altered to zeolites and therefore do not transmit water readily, except possibly along fault zones. Other than a few tests that were detonated within the lower carbonate-rock aquifer, available data are insufficient to asses the extent of test-generated contaminants migrating downward through the tuff units into the underlying lower carbonate-rock aquifer.

Pahute Mesa has been the location for 85 tests, 77 of which were detonated near or below the water table. The mesa provided sites for the deepest and largest yield tests and contains about two-thirds of the total nuclear yield generated by the testing program. The subsurface hydrologic environment at Pahute Mesa is complex because water moves primarily through fractures in discontinuous lava-flow and welded-tuff aquifers that are embedded in the tuff confining unit and are offset and broken by caldera forming and younger high-angle faults. Ground water generally flows across the test area under the influence of a south-southwest hydraulic gradient away from recharge areas in the eastern and northern parts of Pahute Mesa, and exits across the southern margins of the test area. All but a few tests in the extreme western area of testing were detonated within the Silent Canyon caldera complex. This region outside the caldera complex is characterized by higher water levels that form a local discontinuity in the hydraulic gradient that is approximately 
coincident with the boundary of the Oasis Valley subbasin and the buried structural margin of the Silent Canyon caldera complex. The specific cause, exact location, and the full areal extent of the hydrologic discontinuity is unknown because of a lack of drill-hole control outside the test area and because of younger, flat-lying volcanic deposits that obscure the geology that controls ground-water flow to downgradient discharge areas.

A review of existing literature indicates that the mechanical, thermal, and hydrologic effects of underground nuclear detonations are only known in broad general terms and have been studied only for a few small-yield explosions. The explosion produces a roughly spherical cavity of vaporized rock and test debris, and a surrounding zone of crushed and fractured rock that may contain injected contaminants out to a distance of about five cavity radii. Initially, ground water is expelled from the explosion zone causing a local annular rise in the water table around the explosion area. The rise eventually dissipates as ground water flows outward and inward to near equilibrium levels. Long-term hydrologic effects, such as sustained pressurized zones with confining units, have been noted, particularly in Yucca Flat. In the north-central part of the Yucca Flat basin, the water table has been elevated; farther south, hydraulic pressures within the tuff confining units are unusually high. Few systematic studies have been made of the extent of fracturing around cavity zones, the changes in rock permeability, the distribution of radionuclide and chemical contaminants, hydrologic effects of the collapsed chimney, or the thermal effects of underground detonations.

The preceding discussion summarizes what is known and inferred about the ground-water flow system at NTS and identify many elements that are little known and those properties that lack precise measurement. The objective of the USDOE Environmental Restoration Program is not to eliminate every hydrogeologic uncertainty, but rather to acquire sufficient knowledge from which to develop and implement efficient and cost-effective strategies for remediation (U.S. Department of Energy, 1990b, p. 10-17). Much of this knowledge would be acquired during the early characterization phases of the program. The following discussion highlights some of the hydrogeologic uncertainties discussed in the report and is intended to help prioritize investigations that would best characterize the ground-water flow system.
Important factors in developing a strategy to remediate contaminated ground water include knowledge of (1) the contaminant sources in terms of substances, quantities, distribution, and physical-chemical conditions; (2) the flow paths between contaminant sources and potential points of biological exposure; (3) the rate of ground-water flow; and (4) other processes controlling the fate and transport of contaminants along these flow paths. Contaminants at NTS have been introduced over large areas and at various depths, and the flow paths between contaminant sources and potential receptor populations span great distances. A strategy for remediating these contaminants, whether by removal, containment, treatment, or monitoring, would be enhanced by refining the current understanding of ground-water flow through this vast and hydrogeologically complex region. Uncertainties in the current understanding of the subsurface geology and hydrology are many, and many of the technical issues associated with resolving these uncertainties are complex.

Pioneering work throughout the 1960 's and 1970 's provides a substantial base from which to begin ground-water characterization. These early efforts, along with more recent investigations, have identified many of the regional controls on ground-water flow; including the general areas of recharge and discharge, the principal aquifers and confining units, and the major geologic structures. Although early conceptualizations of ground-water flow, based in part on these regional controls, led to the delineation of groundwater basins and subbasins and a general understanding of ground-water flow directions, many issues still remain unresolved at this broad scale. Those issues most pertinent to the assessment and remediation of NTS have to do with the nature and location of individual subbasin boundaries and the qualitative character of the estimates of flow rates and flow components. The resolution of these issues can be hastened by acquiring a more definitive understanding of the following: discharge at Oasis Valley, Ash Meadows, and Death Valley; recharge in the Pahute Mesa area and at other higher elevation localities; and lateral flow into and across subbasin boundaries. In addition, wells and test holes along with geophysical surveys and geologic mapping would provide geologic and hydrologic information to fill major data gaps, especially in the areas between underground testing and downgradient discharge. 
Smaller-scale issues also need to be investigated because system controls are characterized by heterogeneities over distances of a few feet to a few miles. Examples of such issues include the distribution of contaminant sources; the mechanical and hydraulic effects of underground testing; the chemical reactions among the rock, water, and contaminant; and the rock properties that control ground-water flow. These types of spatial variation can result in preferential and locally unique flow paths, and are particularly relevant to assessing risk at NTS where contaminants can be highly toxic and long lived. Smaller scale controls and their effect on directions and rates of ground-water flow need to be understood if estimates of traveltime and concentrations at points of exposure are to be defended against public and regulatory scrutiny. Localscale controls also are important in locating and constructing monitoring wells and in interpreting data from monitoring wells and other holes drilled in the test areas.

Investigators made some progress in identifying and defining smaller scale controls during the early days of the testing program. During succeeding years, the boundaries of test areas were expanded to accommodate increased activity. As the size and number of test areas grew to include more geologically and hydrologically diverse regions, efforts to collect hydrogeologic data and do supporting science did not keep pace. To fill these critical information gaps in a reasonable amount of time and at a practical cost, some drilling is needed to better identify and constrain principal flow paths away from underground test areas. Subsequent drilling then could be focused primarily on those areas where characterization of smaller scale controls and establishment of long-term monitoring are most critical.

About two-thirds of the test-generated radioactive contaminants have been released into the volcanic aquifers and confining units beneath Pahute Mesa (Bryant and Fabryka-Martin, 1991, table 2), but the present knowledge is insufficient to evaluate the quantity of ground-water flowing southwestward to Oasis Valley, southward beneath Timber Mountain, or southeastward beneath Fortymile Canyon. Oasis Valley, a major area of ground-water discharge, warrants particular attention because of its proximity to past tests at Pahute Mesa (only about $17 \mathrm{mi}$ ) and because the major hydrogeologic units and structural controls along flow paths from Pahute Mesa into Oasis Valley are uncertain. Is the limited-flow barrier (apparently coincident with the topographic wall of the Silent Canyon caldera complex in western Area 20) a real hydrologic feature? Is it caused by a specific geologic structure, and does it extend southward into the younger Timber Mountain caldera? What is the hydrologic significance of the Timber Mountain dome? Is it a recharge area, a barrier, or does it constitute a fractured-rock aquifer? What are the hydrologic effects of young, high-angle northtrending faults on ground-water flow? To what depths are flow paths likely to extend beneath and away from contaminated areas? How do fractures control flow rates, directions, and pathways? How are flow paths altered by the discontinuity of volcanic aquifers? What chemical and physical reactions result as a consequence of the heat and energy released by a nuclear detonation? How do these test-induced reactions alter the ground-water flow paths and the transport of testgenerated contaminants?

Most tests at NTS have been detonated in valleyfill alluvium and volcanic rocks beneath Yucca Flat (table 4). Although current data indicate that ground water moves downward through these units into the underlying lower carbonate-rock aquifer, southward beneath Frenchman Flat, and then southwestward to a downgradient discharge area (probably Ash Meadows), little is known about the controlling processes. Of the limited number of drill holes open to carbonate rock, only a few penetrate more than a hundred feet into saturated section, and no quantitative studies have assessed the hydraulic connection between the lower carbonate-rock aquifer and overlying saturated units in Yucca and Frenchman Flats. Thus, studies are needed to ascertain where and how fast water moves from areas of testing into the underlying lower carbonaterock aquifer. Does downward leakage take place primarily along faults, through dispersed fractures, or over the entire area where the carbonate-rock aquifer is confined by overlying units? What is the role of the Carpetbag-Yucca fault system in controlling flow into the carbonate-rock aquifer? How effective are the Eleana Formation and Chainman Shale as a confining unit? Do they form a continuous hydrologic divide between the Ash Meadows and Alkali-Flat Furnace Creek Ranch ground-water subbasins, and do they effectively block downward flow throughout their subsurface extent? Do carbonate rocks beneath the Eleana Formation convey moderate and large quantities of water and are they an active part of the lower carbonate-rock aquifer? If so, does ground water in these rocks flow into Yucca and Frenchman Flats or 
vice-versa? What is the role of fractures in controlling ground-water flow through carbonate rocks-do they create highly irregular and less predictable flow paths?

At Rainier Mesa and Shoshone Mountain, detonations have been relatively small in yield, and have taken place primarily in volcanic confining units above the water table. Nonetheless, a general understanding of the hydrogeology would permit a clearer assessment of the potential risk. Much less is known about groundwater conditions because few drill holes have reached the water table and even fewer have penetrated any significant thickness of saturated rock. Basic questions remain regarding depth to the water table, configuration of the potentiometric surface, and rocks that make up the flow system beneath these test areas. Specific questions concern the nature and location of the boundary between the Ash Meadows subbasin and the Alkali Flat-Furnace Creek Ranch subbasin in these areas; the hydrologic significance of dolomite beneath the volcanic section and the low-angle faults between dolomite and the Eleana Formation at Rainier Mesa; and the potential for local recharge to transport contaminants downward into the saturated-flow system.

Farther downgradient from the immediate areas of underground testing, ground water and its dissolved contaminants traverse complex and lesser studied geologic terranes. The subsurface geology of the Rock Valley fault system needs further study to establish flow paths between Frenchman Flat and downgradient discharge areas (Ash Meadows and possibly Alkali Flat and Death Valley). Such studies would address the possibility that low hydraulic gradients in this area reflect highly permeable rocks within the carbonate-rock aquifer and the likelihood of channeled flow, as was proposed by Winograd and Pearson (1976).

Several questions concerning the effects of nuclear tests on the movement of ground water and contaminant also seem worthy of investigation. How and for how long does a nuclear test affect water levels? What is the distribution of radioactive substances around the point of detonation, and what processes control the initial distribution of refractory and volatile substances? What is the post-shot distribution of fractures, and what is the permeability of fractured rock around the detonation point and in the chimney? What are the cumulative hydrologic, mechanical, thermal, and chemical effects that arise from multiple nuclear tests detonated in close proximity, and how might multiple events alter the distribution and accessibility of radionuclides to ground water? What are the thermal and mechanical effects near the point of nuclear detonation and how do they alter the ability of the rock to retain or transmit contaminants? To what extent does circulating hot ground water (resulting from the underground test) act to redistribute radionuclides in the subsurface?

The contaminant sources at NTS are large and distributed over considerable volumes of diverse and complex rock assemblages. Because any risk to human health or environmental quality depends on knowledge of how and where these contaminants migrate, the definition and quantification of ground-water flow away from the areas of testing are of importance. A costeffective approach would be first to identify the major ground-water controls and to identify and explore the principal aquifers and confining units. Once constrained by adequate data, more complicated and expensive well designs could be used to determine heads within and between individual aquifers, quantify aquifer and confining-unit properties, and explore the interconnections of aquifers along the principal flow paths, specifically in those areas where detailed characterization is most critical. This staged approach also would expedite selection and help minimize the number of sites that would be necessary for long-term monitoring or that may be needed to support the selection and implementation of a remedial strategy.

\section{REFERENCES CITED}

Armstrong, R.L., 1968, Sevier orogenic belt in Nevada and Utah: Geological Society of America Bulletin, v. 79, p. 429-458.

Barnes, Harley, Ekren, E.B., Cleaves, L.R., and Hedlund, D.C., 1982, Geologic and tectonic maps of the Mercury quadrangle, Nye and Clark Counties, Nevada: U.S. Geological Survey Miscellaneous Investigations Map I-1197, scale 1:24,000.

Barnes, Harley, and Poole, F.G., 1968, Regional thrust-fault system in Nevada Test Site and vicinity, in Eckel, E.B., ed., Nevada Test Site: Geological Society of America . Memoir 110, p. 233-238.

Blankennagel, R.K., and Weir, J.E., Jr., 1973, Geohydrology of the eastern part of Pahute Mesa, Nevada Test Site, Nye County, Nevada: U.S. Geological Survey Professional Paper 712-B, $35 \mathrm{p}$.

Boardman, C.R., 1970, Engineering effects of underground nuclear explosives: Symposium on Engineering with Nuclear Explosives, Las Vegas, Nev., Proceedings, CONF-700101, p. 43-67. 
Boardman, C.R., Rabb, D.D., and McArthur, R.D., 1969, Responses of four rock mediums to contained nuclear explosions: Journal of Geophysical Research, v. 69, no.16, p. 3457-3469.

Boardman, C.R., and Skrove, J., 1966, Distribution in fracture permeability of a granite rock mass following a contained nuclear explosion: Journal of Petroleum Technology, v. 18, p. 629-623.

Borg, I.Y., Stone, R., Levy, H.B., and Ramspott, L.D., 1976, Information pertinent to the migration of radionuclides in ground water at the Nevada Test Site, Part 1, Review and analysis of existing information: Lawrence Livermore National Laboratory Report UCRL-52078 Part 1, 216 p.

Brikowski, T.H., 1992, Estimates of potential radionuclide migration at the Bullion site: University of Nevada, Desert Research Institute Publication 45097, 26 p.

Bryant, E.A., 1992, The Cambric migration experimentA summary report: Los Alamos National Laboratory Report, LA-12335-MS, 37 p.

Bryant, E.A., and Fabryka-Martin, June, 1991, Survey of hazardous materials used in nuclear testing: Los Alamos National Laboratory Report LA-12014-MS, 12 p.

Burbey, T.J., and Wheatcraft, S.W., 1986, Tritium and chlorine-36 migration from a nuclear explosion cavity: University of Nevada, Desert Research Institute Publication 45050, $147 \mathrm{p}$.

Burkhard, N.L., and Rambo, J.T., 1991, One plausible explanation for water mounding [abs.], in Olsen C.W., and Price E.M., eds., Sixth Symposium on the Containment of Underground Nuclear Explosions, Reno, Nev., Lawrence Livermore National Laboratory, Proceedings, CON-9109114, p. 145-158.

Byers, F.M., Jr., Carr, W.J., Orkild, P.P., Quinlivan, W.D., and Sargent, K.A., 1976, Volcanic suites and related cauldrons of Timber Mountain-Oasis Valley caldera complex, southern Nevada: U.S. Geological Survey Professional Paper 919, 70 p.

Cardinalli, J.L., Roach, L.M., Rush, F.E., and Vasey, B.J., comps, 1968, State of Nevada hydrographic areas: Nevada Division of Water Resources map, scale 1:500,000.

Carr, W.J., 1974, Summary of tectonic and structural evidence for stress orientation at the Nevada Test Site: U.S. Geological Survey Open-File Report 74-176, 53 p.

Carr, W.J., Bath, G.D., Healy, D.L., and Hazelwood, R.M., 1975, Geology of northern Frenchman Flat, Nevada Test Site: U.S. Geological Survey Report 474-216, 24 p. Available only from National Technical Information Service, U.S. Department of Commerce, Springfield, VA 22161
Carr, W.J., Byers, F.M., Jr., and Orkild, P.P., 1986, Stratigraphic and volcano-tectonic relations of the Crater Flat Tuff and some older volcanic units, Nye County, Nevada: U.S. Geological Survey Professional Paper $1323,28 \mathrm{p}$.

Carroll, R.D., 1981, Seismic velocities and postshot properties in and near chimneys: Monterey Containment Symposium, Monterey, Calif., Los Alamos National Laboratory, Proceedings, LA-9211-C, p. 379-396.

Cashman, P.H., and Trexler, J.H., Jr., 1991, The Mississippian Antler foreland and continental margin in southern Nevada - The Eleana Formation reinterpreted, in Cooper, J.D., and Stevens, C.H., eds., Paleozoic paleogeography of the western United States-II, Pacific section: Society of Economic Paleontologists and Mineralogists, v. 67, p. 271-280.

Cashman, P.H., and Trexler, J.H., Jr., 1994, The case for two, coeval Mississippian sections at the Nevada Test Site, in McGill, S.F., and Ross, T.M., eds., Geologic investigations of an active margin: Geological Society of America Cordilleran Section Guidebook, San Bernardino, Calif., p. 76-81.

Caskey, S.J., 1991, Mesozoic and Cenozoic structural geology of the CP Hills, Nevada Test Site, Nye County, Nevada, and regional implications: University of Nevada, Reno, unpublished M.S. thesis, 90 p.

Caskey, S.J., and Schweickert, R.A., 1992, Mesozoic and Cenozoic deformation in the Nevada Test Site and vicinity-Implications for structural framework of the Cordilleran fold and thrust belt and Tertiary extension north of Las Vegas Valley: Tectonics, v. 11, no. 6, p. 1314-1331.

Cherry, J.T., Larson, D.B., and Rapp, E.G., 1968, Computer calculations of the Gasbuggy event: Lawrence Radiation Laboratory Report UCRL-50419, $10 \mathrm{p}$.

Claassen, H.C., 1973, Water quality and physical characteristics of Nevada Test Site water-supply wells: U.S. Geological Survey Report 474-158, 145 p. Available only from National Technical Information Service, U.S. Department of Commerce, Springfield, VA 22161.

1985, Sources and mechanisms of recharge for ground water in the west-central Amargosa Desert, Nevada - a geochemical interpretation: U.S. Geological Survey Professional Paper 712-F, 31 p.

Claassen, H.C., and Cordes, E.H., 1975, Two-well recirculating tracer test in fractured carbonate rock, Nevada: Hydrological Sciences, Bulletin XX, no. 3, p. 367-382.

Cole, J.C., Harris, A.G., Lanphere, M.A., Barker, C.E., and Warren, R.G., 1993, The case for pre-middle Cretaceous extensional faulting in northern Yucca Flat, southwestern Nevada [abs]: Geological Society of America, Abstracts with Programs, vol. 25, no. 5, p. 22. 
Cole, J.C, Trexler, J.H., Jr., Cashman, P.H., and Hudson, M.R., 1994, Structural and stratigraphic relations of Mississippian rocks at the Nevada Test Site, in McGill, S.F., and Ross, T.M., eds., Geological investigations of an active margin: Geological Society of America Cordilleran Section Guidebook, San Bernardino, Calif., p. 66-75.

Cole, J.C., Wahl, R.R., and Hudson, M.R., [1990], Structural relations within the Paleozoic basement of the Mine Mountain block; implications for interpretations of gravity data in Yucca Flat, Nevada Test Site: Fifth Symposium on the Containment of Underground Nuclear Explosions, Santa Barbara, Calif., Lawrence Livermore National Laboratory, Proceedings, CONF-8909163, v. 2, p. 431-456.

Covington, H.R., [1990], The Delamar fracture zone-Recognition of unmapped zones of weakness on Pahute Mesa, Nevada Test Site: Fifth Symposium on the Containment of Underground Nuclear Explosions, Santa Barbara, Calif., Lawrence Livermore National Laboratory, Proceedings, CONF-8909163, v. 2, p. 405-416.

Crow, N.B., 1976, First observations of tritium in ground water outside chimneys of underground nuclear explosions, Yucca Flat, Nevada Test Site: Lawrence Livermore Laboratory Report UCRL-52073, 35 p.

Czarnecki, J.B., and Waddell, R.K., 1984, Finite-element simulation of ground-water flow in the vicinity of Yucca Mountain, Nevada-California: U.S.Geological Survey Water-Resources Investigations Report 84$4349,38 \mathrm{p}$.

Delort, F., and Supiot, F., 1970, Nuclear stimulation of oilreservoirs: Symposium on Engineering with Nuclear Explosives, Las Vegas, Nev., Proceedings, CONF700101, v. 1, p. 649-661.

Derlich, S., 1970, Underground nuclear explosion effects in granite-rock fracturing: Symposium on Engineering with Nuclear Explosives, Las Vegas, Nev., Proceedings, CONF-700101, v. 1, p. 505-518.

Dettinger, M.D., 1989, Distribution of carbonate-rock aquifers in southern Nevada and the potential for their development-Summary of findings, 1985-88: Carson City, Nev., Program for the Study and Testing of Carbonate-Rock Aquifers in Eastern and Southern Nevada, Summary Report No. 1, 37 p.

Dickey, D.D., 1968, Fault displacement as a result of underground nuclear explosions, in Eckel, E.B., ed., Nevada Test Site: Geological Society of America Memoir 110, p. 219-232.

Doty, G.C., and Rush, F.E., 1985, Inflow to a crack in playà deposits of Yucca Lake, Nevada Test Site, Nye County, Nevada: U.S. Geological Survey Water-Resources Investigations Report 84-4296, 24 p.
Doty, G.C., and Thordarson, William, 1983, Water table in rocks of Cenozoic and Paleozoic age, 1980, Yucca Flat, Nevada Test Site, Nevada: U.S. Geological Survey Water-Resources Investigations Report 83-4067, 1 sheet, scale 1:48,000.

Dudley, W.W., Jr., and Larson, J.D., 1976, Effects of irrigation pumping on desert pupfish habitats in Ash Meadows, Nye County, Nevada: U.S. Geological Survey Professional Paper 927, $52 \mathrm{p}$.

Dudley, W.W., Jr., Wollitz, L.E., Baldwin, D.A., and Claassen, H.C., 1971, Geologic and hydrologic effects of the Handley event, Pahute Mesa, Nevada Test SiteEffects on wells and aquifers: U.S. Geological Survey Report 474-95, 71 p. Available only from National Technical Information Service, U.S. Department of Commerce, Springfield, VA 22161.

Eakin, T.E., Maxey, G.B., Robinson, T.W., Fredricks, J.C., and Loeltz, O.J., 1951, Contributions to the hydrology of eastern Nevada: Nevada State Engineer, Water Resources Bulletin 12, 171 p.

Erikson, S.J., 1991, Report of drilling and radionuclide migration investigations at UE-20n\#1, Pahute Mesa, Nevada Test Site, 1987: University of Nevada, Desert Research Institute Publication 45081, 118 p.

Feeney, T.A., Campana, M.E., and Jacobson, R.L., 1987, A deuterium-calibrated groundwater flow model of the western Nevada Test Site and vicinity: University of Nevada, Desert Research Institute Publication 45057, $46 \mathrm{p}$.

Frizzell, V.A., Jr., and Shulters, Jacqueline, 1990, Geologic map of the Nevada Test Site, southern Nevada: U.S. Geological Survey Miscellaneous Investigations Map I-2046, 1 sheet, scale 1:100,000.

Garber, M.S., 1971, A method for estimating effective porosity in a rubble chimney formed by an underground nuclear explosion, in U.S. Geological Survey Research 1971: U.S. Geological Survey Professional Paper 750C, p. C207-C209.

Gibbons, A.B., Hinrichs, E.N., Hanson, W.R. and Lemke, R.W., 1963, Geology of the Rainier Mesa quadrangle, Nye County, Nevada: U.S. Geological Survey Geologic Quadrangle Map GQ-215.

Grow, J.A., Barker, C.E., and Harris, A.G., 1994, Oil and gas exploration near Yucca Mountain, southern Nevada: American Nuclear Society International High-Level Radioactive Waste Management Conference, Las Vegas, Nev., Proceedings, p. 1-18.

Guth, P.L., 1981, Tertiary extension north of the Las Vegas Valley shear zone, Sheep and Desert Ranges, Clark County, Nevada: Geological Society of America Bulletin, v. 92, p. 763-771. 
1990, Superposed Mesozoic and Cenozoic deformation, Indian Springs quadrangle, southern Nevada, in Wernicke, B.P., ed., Basin and Range extensional tectonics near the latitude of Las Vegas, Nevada: Geological Society of America Memoir 176, p. 237-249.

Hamilton, W., 1988, Detachment faulting in the Death Valley region, California and Nevada, in Carr, M.D., and Yount, J.C., eds., Geologic and hydrologic investigations of a potential nuclear waste disposal site at Yucca Mountain, southern Nevada: U.S. Geological Survey Bulletin 1790, p. 51-85.

Harrill, J.R., Gates, J.S., and Thomas, J.M., 1988, Major ground-water flow systems in the Great Basin region of Nevada, Utah, and adjacent states: U.S. Geological Survey Hydrologic Investigations Atlas HA-694-C, 2 sheets, scale 1:1,000,000.

Hawkins, W.L., Cavazos, A.P., and Thompson, P.H., 1988, Geologic and hydrologic investigations at the Aleman (U3KZ) site, and other sites in Yucca Flat, the Nevada Test Site, in Olsen, C.W., Donahue, M.L., and Wanden, S.W., eds: Fourth Symposium on the Containment of Underground Nuclear Explosions: Colorado Springs, Colo., Sandia National Laboratory, Proceedings, CONF-870961, v. 2, p. 387-398.

Hawkins, W.L., Trudeau, D.A., and Mihevc, T.M., 1990, Hydrologic testing in exploratory drill hole U-4t, Yucca Flat, the Nevada Test Site, in Olsen, C.W., and Carter, J.A., eds., Fifth Symposium on the Containment of Underground Nuclear Explosions: Santa Barbara, Calif., Lawrence Livermore National Laboratory, Proceedings, CONF-8909163, v. 2, p. 141-159.

Higgins, G.H., 1959, Evaluation of ground-water contamination hazard from underground nuclear explosions: Journal of Geophysical Research, v. 64, p. 1509-1519.

-1970, Underground nuclear explosions: Symposium on Engineering with Nuclear Explosives, Las Vegas, Nev., Proceedings, CONF-700101, p. 29-42.

Hodges, K.V., and Walker, J.D., 1992, Extension of the Cretaceous Sevier orogeny, North American Cordillera: Geology, v. 104, p. 560-569.

Holzer, A., 1970, Gasbuggy in perspective: Symposium on Engineering with Nuclear Explosives, Las Vegas, Nev., Proceedings, CONF-700101, v. 1, p. 29-42.

Hoover, D.L., and Morrison, J.N., 1980, Geology of the Syncline Ridge area related to nuclear waste disposal, Nevada Test Site, Nye County, Nevada: U.S. Geological Survey Open-File Report 80-942, 70 p., 1 sheet, scale $1: 36,360$.

Hoover, D.L., and Trudeau, D.A., 1987, High water levels in drill holes, Yucca Flat, Nevada Test Site: Fourth Symposium on the Containment of Underground Nuclear Explosions, Colorado Springs, Colo., Sandia National Laboratory, Proceedings, CONF-870961, v. 2, p. 363372.
Houser, F.N., and Poole, F.G., 1960, Preliminary geologic map of the Climax Stock and vicinity, Nye County, Nevada: U.S. Geological Survey Miscellaneous Investigations Map I-328, 2 sheets, scale 1:4,800.

Hudson, B.C., and Smith, J.R., 1981, Cavity radius uncertainties: First Symposium on the Containment of Underground Nuclear Explosions, Monterey, Calif., Los Alamos National Laboratory, Proceedings, LA9211-C, p. 413-417.

Hudson, M.R., 1992, Paleomagnetic data bearing on the origin of arcuate structures in the French Peak-Massachusetts Mountain area of southern Nevada: Geological Society of America Bulletin, v. 104, p. 581-594.

Hunt, C.B., Robinson, T.W., Bowles, W.A., and Washburn, A.L., 1966, Hydrologic basin, Death Valley, California: U.S. Geological Survey Professional Paper 494-B, $138 \mathrm{p}$.

Knox, J.B., Rawson, D.E., and Korver, J.A., 1965, Analysis of a groundwater anomaly created by an underground nuclear explosion: Journal of Geophysical Research, v. 70 , no. 4 , p. 823-835.

Lombard, D.B., Bray, B.G., and Sohns, H.W., 1970, Technical considerations for Plowshare applications to oil shale: Symposium on Engineering with Nuclear Explosives, Las Vegas, Nev., Proceedings, CONF-700101, p. 1343-1363.

Lyles, B.F., 1993, Tritium activities in selected wells on the Nevada Test Site: University of Nevada, Desert Research Institute Publication 45104, $26 \mathrm{p}$.

Maldonado, F., 1977, Composite postshot fracture map of Pahute Mesa, Nevada Test Site, June 1973 through March 1976: U.S. Geological Survey Report 474-243, 8 p. Available only from National Technical Information Service, U.S. Department of Commerce, Springfield, VA 22161.

Malmberg, G.T., and Eakin, T.E., 1962, Ground-water appraisal of Sarcobatus Flat and Oasis Valley, Nye and Esmeralda Counties, Nevada: Nevada Department of Conservation and Natural Resources, Ground Water Resources - Reconnaissance Report 10,39 p.

Monsen, S.A., Carr, M.D., Reheis, M.C., and Orkild, P.P., 1990, Geologic map of Bare Mountain, Nye County, Nevada: U.S. Geological Survey Open-File Report 9025, 17 p., 1 sheet, scale 1:24:000.

Nimz, Gregory, and Thompson, J.L., 1992, Underground radionuclide migration at the Nevada Test Site: U.S. Department of Energy Report DOE/NV-346, 17 p.

Office of Technology Assessment, 1989, The containment of underground nuclear explosions: U.S. Congress Report OTA-ISC-414, $80 \mathrm{p}$.

1991, Complex cleanup-The environmental legacy of nuclear weapons production: U.S. Congress Report OTA-O-484, $212 \mathrm{p}$. 
Orkild, P.P., Sargent, K.A., and Snyder, R.P., 1969, Geologic map of the Pahute Mesa, Nevada Test Site and vicinity, Nye County, Nevada: U.S. Geological Survey Miscellaneous Investigations Map I-567, 5 p., 1 sheet, scale $1: 48,000$.

Peterman, Z.E., Stuckless, J.S., Downey, J.S., and Gutentag, E.D., 1990, Strontium-isotope geochemistry of the Ash Meadows ground-water system in southern Nevada [abs.]: Geological Society of America, Abstracts with Program, v. 22, no. 7, p. 295-296.

Piper, A.M., and Stead, F.W., 1965, Potential applications of nuclear explosives in development and management of water resources-Principles: U.S. Geological Survey Open-File Report TEI-857, 128 p.

Poole, F.G., 1974, Flysch deposits of Antler foreland basin, western United States, in Dickenson, W.R., ed., Tectonics and sedimentation: Society of Economic Paleontologists and Mineralogists Special Publication 22, p. 5882.

Poole, F.G., Houser, F.N., and Orkild, P.P., 1961, Eleana formation of Nevada Test Site and vicinity, Nye County, Nevada: U.S. Geological Survey Professional Paper 424-D, p. D104-D111.

Poole, F.G., and Sandberg, C.A., 1991, Mississippian paleogeography and conodont biostratigraphy of the western United States, in, Cooper, J.D., and Stevens, C.H., eds., Paleozoic paleogeography of the western United States-II, Pacific section: Society of Economic Paleontologists and Mineralogists, v. 67, p. 107-136.

Prudic, D.E., Harrill, J.R., and Burbey, T.J, 1995, Conceptual evaluation of regional ground-water flow in the carbonate-rock province of the Great Basin, Nevada, Utah, and adjacent states: U.S. Geological Survey Professional Paper 1409-D, 102 p.

Rogers, L.A., 1970, Determining the effects on the Gasbuggy reservoir from computer simulation of the postshot gas production history: Symposium on Engineering with Nuclear Explosives, Las Vegas, Nev., Proceedings, CONF-700101, p. 698-721.

Rush, F.E., 1968, Index of hydrographic areas in Nevada: Nevada Division of Water Resources, Information Report 6, 38 p.

Rush, F.E., 1970, Regional ground-water systems in the Nevada Test Site area, Nye, Lincoln, and Clark Counties, Nevada: Nevada Division of Water Resources Reconnaissance Report 54, 24 p.

Russell, C.E., Hess, J.W., and Tyler, S.W., in press, Hydrogeologic investigation of flow in fractured tuffs, Rainier Mesa, Nevada Test Site: University of Nevada, Desert Research Institute Publication 45062, 25 p.
Sadler, W.R., Campana, M.E., Jacobson, R.L., and Ingrahm, N.L., 1992, A deuterium-calibrated, discrete-state compartment model of regional groundwater flow, Nevada Test Site and vicinity: University of Nevada, Desert Research Institute Publication 45088, $77 \mathrm{p}$.

Savard, C.S., 1990, Evidence for the boundary between the Oasis Valley and Alkali-Flat Furnace Creek Ranch ground-water subbasins, Nevada [abs.]: EOS, American Geophysical Union Transactions, v. 70, no. 43, p. 1100.

Sawyer, D.A., Fleck, R.J., Lanphere, M.A., Warren, R.G., and Broxton, D.E., 1990, Episodic volcanism in the southwest Nevada volcanic field-New $\mathrm{Ar}^{40} / \mathrm{Ar}^{39}$ geochronologic results: Eos, American Geophysical Union Transactions, v. 71, no. 43, p. 1296.

Sawyer, D.A., Fleck, R.J., Lanphere, M.A., Warren, R.G., Broxton, D.E., and Hudson, M.R., 1994, Episodic caldera volcanism in the Miocene southwestern Nevada volcanic field-Revised stratigraphic framework, $\mathrm{Ar}^{40} / \mathrm{Ar}^{39}$ geochronology, and implications for magmatism and extension: Geological Society of America Bulletin, v. 106, no. 10, p. 1304-1318.

Sawyer, D.A., and Sargent, K.A., 1989, Petrologic evolution of divergent peralkaline magmas from the Silent Canyon caldera complex, southwestern Nevada volcanic field: Journal of Geophysical Research, v. 94, no. B5, p. 6021-6040.

Simonds, F.W., 1989, Geology and hydrothermal alteration at the Calico Hills, Nye County, Nevada: University of Colorado, Boulder, unpublished M.S. thesis, 136 p.

Snyder, R.P., 1971, Composite postshot fracture map of Pahute Mesa, Nevada Test Site: U.S. Geological Survey Report 474-100, 13 p. Available only from National Technical Information Service, U.S. Department of Commerce, Springfield, VA 22161.

Stewart, J.H., and Carlson, J.E., 1978, Geologic map of Nevada: U.S. Geological Survey, 1:500,000 scale.

Streitz, Robert, and Stinson, M.C., 1974, Geologic map of California, Death Valley Sheet: California Division of Mines and Geology, scale 1:250,000.

Terhune, R.W., 1973, Prediction of nuclear explosion effects for Rio Blanco: Lawrence Livermore Laboratory Report UCRL-51377, 35 p.

Thomas, J.M., 1988, Delineation of regional ground-water flow systems in southern Nevada using isotope and chemical data [abs.]: Geological Society of America, Abstracts with Programs, v. 20, no. 7, p. A363.

Thordarson, William, 1965, Perched ground water in zeolitized-bedded tuff, Rainier Mesa and vicinity, Nevada Test Site, Nevada: U.S. Geological Survey Open-File Report TEI-862, $90 \mathrm{p}$. 1985, Hydrologic monitoring at the Faultless site, Nye County, Nevada: U.S. Geological Survey OpenFile Report 84-580, $37 \mathrm{p}$. 
-1987, Hydrogeology of the Faultless site, Nye County, Nevada: U.S. Geological Survey WaterResources Investigations Report 86-4342, $40 \mathrm{p}$.

U.S. Department of Energy, 1990a, Site specific plan for environmental restoration and waste managementFive-year plan: U.S. Department of Energy, Nevada Operations Office, DOE/NV-336, $234 \mathrm{p}$.

-1990b, Environmental restoration and waste management-Five year plan for fiscal years 1992-1996: U.S. Department of Energy, DOE/S-0078P, 562 p. 1991, Environmental restoration and waste management-Site specific plan for fiscal years 1992-1996: U.S. Department of Energy, Nevada Operations Office, unnumbered report, $274 \mathrm{p}$.

1993, Nevada Test Site, A historical perspective: NTS News and Views, Special Edition, April 1993, $32 \mathrm{p}$.

1994, United States nuclear tests; July, 1945 through September, 1992: U.S. Department of Energy, Nevada Operation Office, DOE/NV-209 (rev. 14), 105 p.

U.S. Environmental Protection Agency, 1991, Offsite environmental monitoring report-Radiation monitoring around United States nuclear test areas calendar year 1990: U.S. Environmental Protection Agency Report, EPA 600/4-91/030 (DOE/DP 00539-063), $171 \mathrm{p}$.

U.S. Geological Survey, 1974, Results of exploration of the Baneberry site, early 1971: U.S. Geological Survey Report 474-145, 94 p. Available only from National Technical Information Service, U.S. Department of Commerce, Springfield, VA 22161.

Waddell, R.K., Robison, J.H., and Blankennagel, R.K., 1984, Hydrology of Yucca Mountain and vicinity, Nevada-California-Investigative results through mid1983: U.S. Geological Survey Water-Resources Investigations Report 84-4267, 72 p.
Walker, G.E., and Eakin, T.E., 1963, Geology and ground water of Amargosa Desert, Nevada-California: Nevada Department of Conservation and Natural Resources, Ground-Water Resources - Reconnaissance Report 14, $45 \mathrm{p}$.

Wernicke, Brian, Axen, G.J., and Snow, J.K., 1988, Basin and Range extensional tectonics at the latitude of Las Vegas: Geological Society of America Bulletin, v. 100, p. 1738-1757.

White, A.F., 1979, Ground water associated with a tuffaceous aquifer, Oasis Valley, Nevada: U.S. Geological Survey Professional Paper 712-E, 25 p.

White, A.F., and Chuma, N.J., 1987, Carbon and isotope mass balance models of Oasis Valley-Fortymile Canyon groundwater basin, southern Nevada: Water Resources Research, v. 23, no. 4, p. 571-582.

Winograd, I.J., and Friedman, Irving, 1972, Deuterium as a tracer of regional ground-water flow, southern Great Basin, Nevada and California: Geological Society of America Bulletin, v. 83, no. 12, p. 3691-3708.

Winograd, I.J., and Pearson, F.J., Jr., 1976, Major carbon-14 anomaly in a regional carbonate aquifer-Possible evidence for megascale channeling, south central Great Basin: Water Resources Research, v. 12, no. 6, p. 11251143.

Winograd, I.J., and Thordarson, William, 1975, Hydrogeologic and hydrochemical framework, south-central Great Basin, Nevada-California, with special reference to the Nevada Test Site: U.S. Geological Survey Professional Paper 712-C, $126 \mathrm{p}$. 